\title{
EXPOSURE EVALUATION FOR BENZENE, LEAD AND NOISE IN VEHICLE AND EQUIPMENT REPAIR SHOPS
}

Thesis for submittal to WSU MASTER OF SCIENCE IN ENVIRONMENTAL SCIENCE

Prepared for the U.S. Department of Energy

Assistant Secretary for Environmental Management

Contractor for the U.S. Department of Energy

under Contract DE-AC06-09RL14728

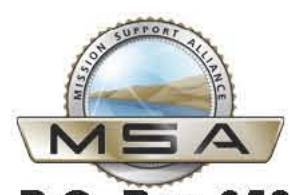

P.O. Box 650

Richland, Washington 99352 
HNF-54935

Revision 0

\title{
EXPOSURE EVALUATION FOR BENZENE, LEAD AND NOISE IN VEHICLE AND EQUIPMENT REPAIR SHOPS
}

Thesis for submittal to WSU MASTER OF SCIENCE IN ENVIRONMENTAL SCIENCE

\author{
L. Sweeney \\ Mission Support Alliance
}

Date Published

April 2013

MSA-SIL

Prepared for the U.S. Department of Energy

Assistant Secretary for Environmental Management

Contractor for the U.S. Department of Energy

under Contract DE-AC06-09RL14728

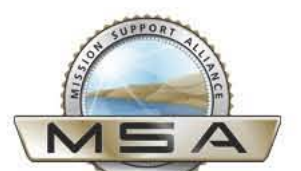

P.O. Box 650

Richland, Washington 99352

Copyright License

By acceptance of this article, the publisher and/or recipient acknowledges the U.S. Government's right to retain a non exclusive, royalty-free license in an to any copyright covering this paper.

\section{APPROVED}

By Janis D. Aardal at 1:43 pm, Apr 10, 2013

Release Approval

Date 
HNF-54935

Revision 0

\section{LEGAL DISCLAIMER}

This report was prepared as an account of work sponsored by an agency of the United States Government. Neither the United States Government nor any agency thereof, nor any of their employees, makes any warranty, express or implied, or assumes any legal liability or responsibility for the accuracy, completeness, or any third party's use or the results of such use of any information, apparatus, product, or process disclosed, or represents that its use would not infringe privately owned rights. Reference herein to any specific commercial product, process, or service by trade name, trademark, manufacturer, or otherwise, does not necessarily constitute or imply its endorsement, recommendation, or favoring by the United States Government or any agency thereof or its contractors or subcontractors. The views and opinions of authors expressed herein do not necessarily state or reflect those of the United States Government or any agency thereof.

This report has been reproduced from the best available copy.

Printed in the United States of America 
EXPOSURE EVALUATION FOR BENZENE, LEAD AND NOISE IN VEHICLE AND EQUIPMENT REPAIR SHOPS

RICHLAND, WASHINGTON

By

LYNN C. SWEENEY

\begin{abstract}
A thesis submitted in partial fulfillment of the requirements for the degree of

MASTER OF SCIENCE IN ENVIRONMENTAL SCIENCE
\end{abstract}

WASHINGTON STATE UNIVERSITY

School of Earth and Environmental Sciences

MAY 2013 
To the Faculty of Washington State University:

The members of the Committee appointed to examine the thesis of LYNN C.

SWEENEY find it satisfactory and recommend that it be accepted.

\begin{tabular}{c}
\hline Allan Felsot, Ph.D., Chair \\
\hline Vincent Hebert, Ph.D. \\
\hline
\end{tabular}

Nancy Butler, CIH 
ACKNOWLEDGMENT 


\title{
EXPOSURE EVALUATION FOR BENZENE, LEAD AND NOISE IN \\ VEHICLE AND EQUIPMENT REPAIR SHOPS
}

\author{
Abstract \\ By Lynn C. Sweeney \\ Washington State University
}

May 2013

Chair: Allan Felsot

An exposure assessment was performed at the equipment and vehicle maintenance repair shops operating at the U.S. Department of Energy Hanford site, in Richland, Washington. The maintenance shops repair and maintain vehicles and equipment used in support of the Hanford cleanup mission. There are three general mechanic shops and one auto body repair shop. The mechanics work on heavy equipment used in construction, cranes, commercial motor vehicles, passenger-type vehicles in addition to air compressors, generators, and farm equipment. Services include part fabrication, installation of equipment, repair and maintenance work in the engine compartment, and tire and brake services. Work performed at the auto body shop includes painting and surface preparation which involves applying body filler and sanding. 8-hour time-weighted-average samples were collected for benzene and noise exposure and task-based samples were collected for lead dust work activities involving painted metal surfaces. Benzene samples were obtained using $3 \mathrm{M}^{\mathrm{TM}}$ 3520 sampling badges and were analyzed for additional volatile organic compounds. These compounds were selected based on material safety data sheet information for the aerosol products used by the mechanics for each day of sampling. The compounds included 
acetone, ethyl ether, toluene, xylene, VM\&P naphtha, methyl ethyl ketone, and trichloroethylene. Laboratory data for benzene, VM\&P naphtha, methyl ethyl ketone and trichloroethylene were all below the reporting detection limit. Airborne concentrations for acetone, ethyl ether, toluene and xylene were all less than $10 \%$ of their occupational exposure limit. The task-based samples obtained for lead dusts were submitted for a metal scan analysis to identify other metals that might be present. Laboratory results for lead dusts were all below the reporting detection limit and airborne concentration for the other metals observed in the samples were less than $10 \%$ of the occupational exposure limit. Noise dosimetry sampling was performed on a random basis and was representative of the different work activities within the four shops. Twenty three percent of the noise samples exceeded the occupational exposure limit of 85 decibels for an 8-hour time-weightedaverage. Work activities where noise levels were higher included use of impact wrenches and grinding wheels. 


\section{TABLE OF CONTENTS}

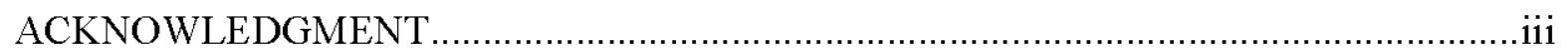

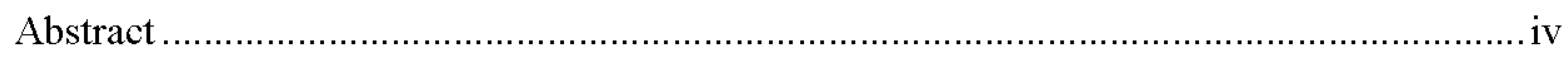

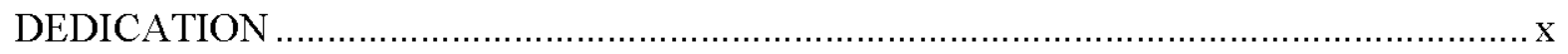

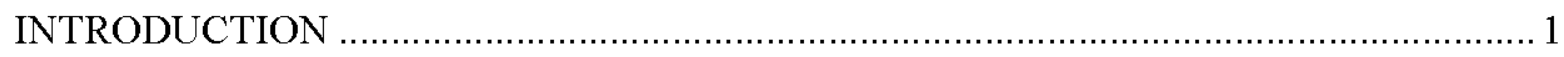

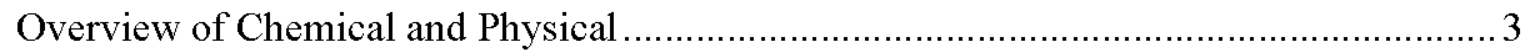

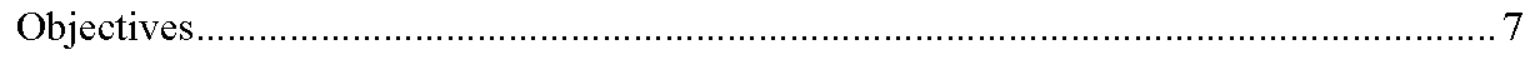

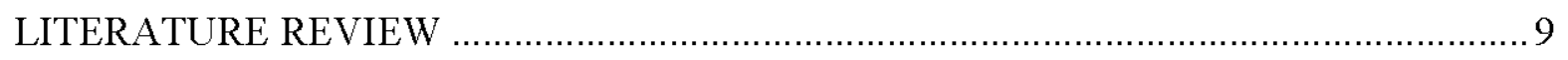

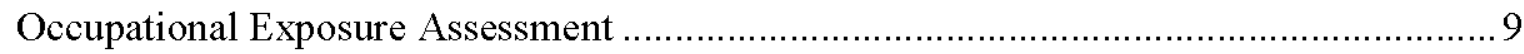

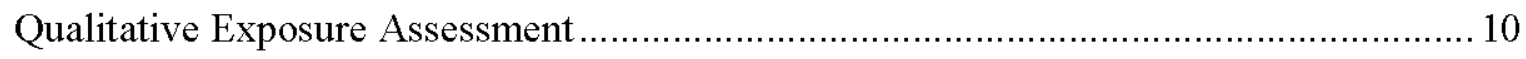

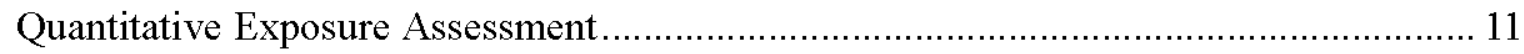

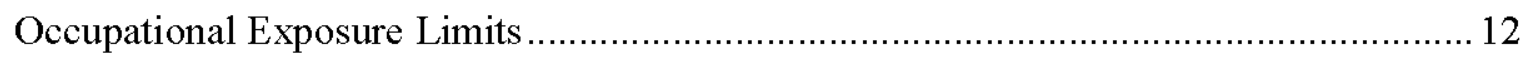

Measuring Employee Exposures to Chemicals ................................................... 14

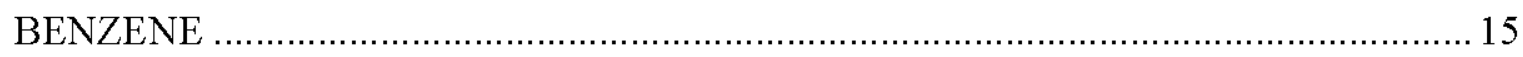

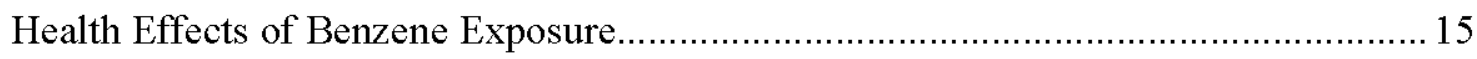

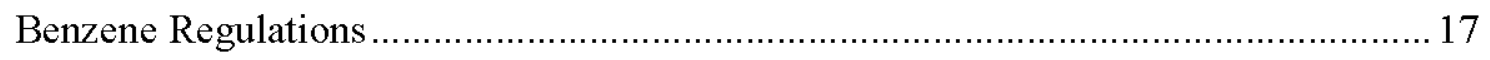

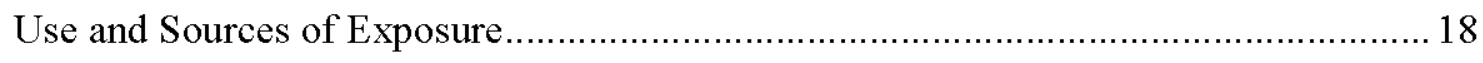

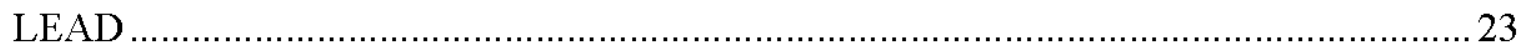

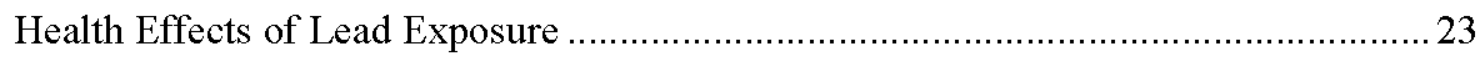

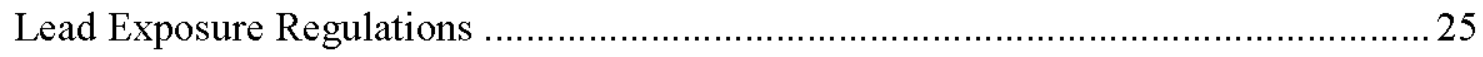

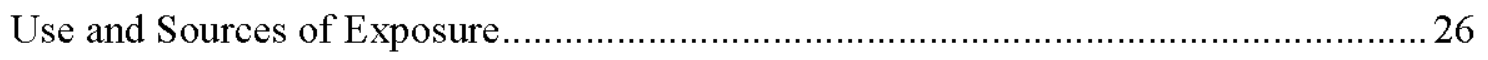

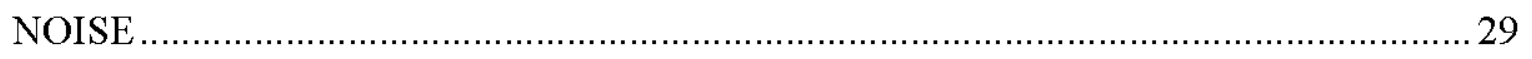

Health Effects of Occupational Noise Exposure............................................... 29 


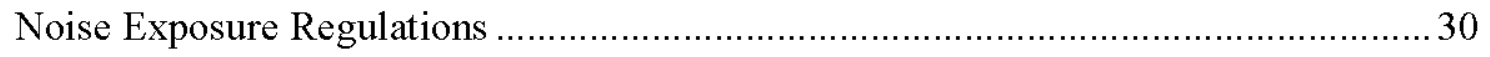

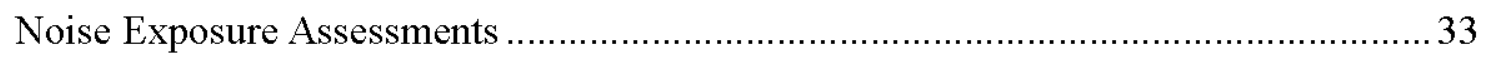

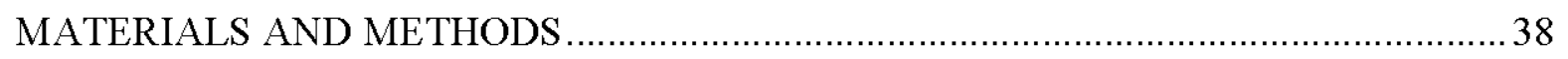

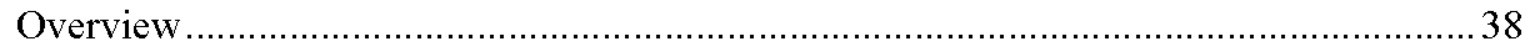

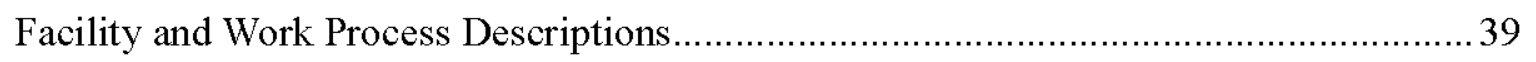

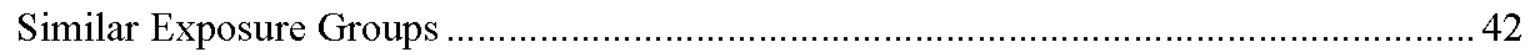

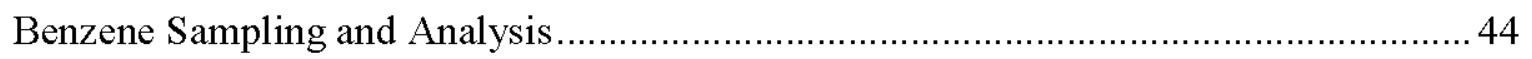

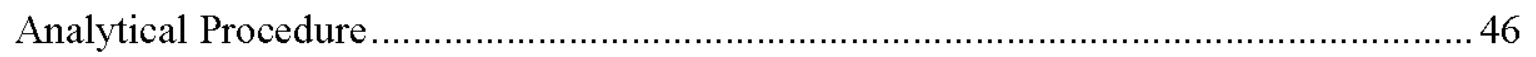

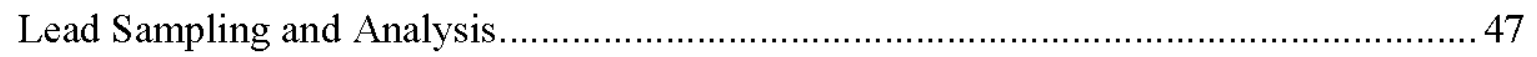

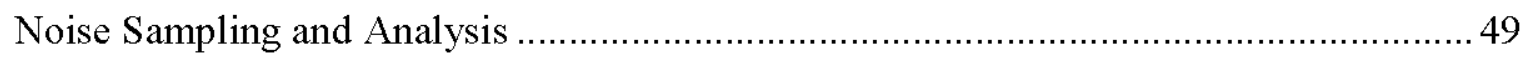

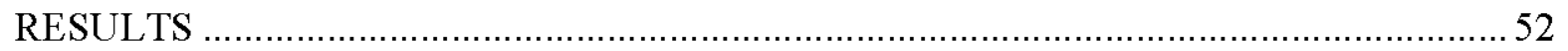

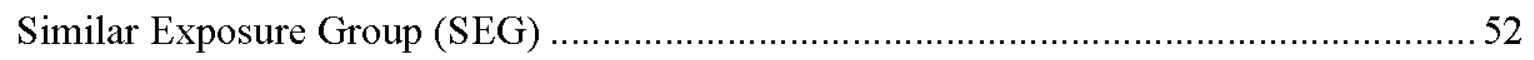

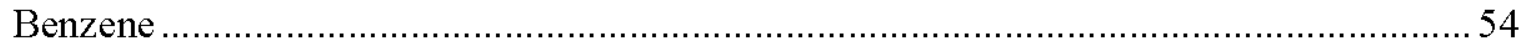

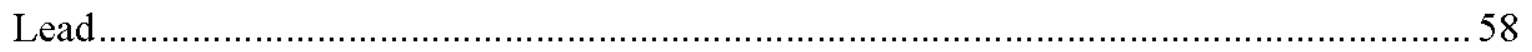

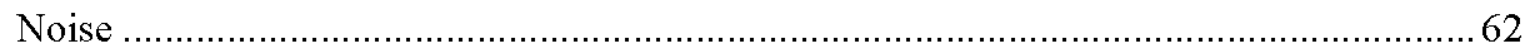

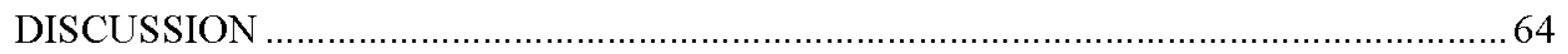

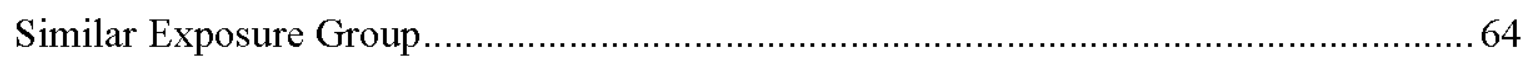

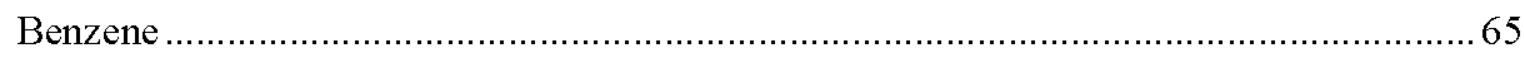

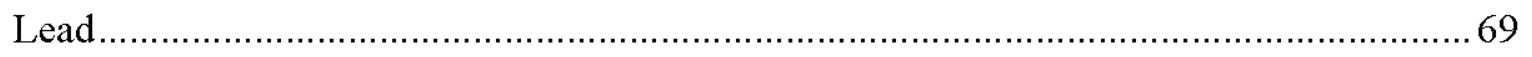

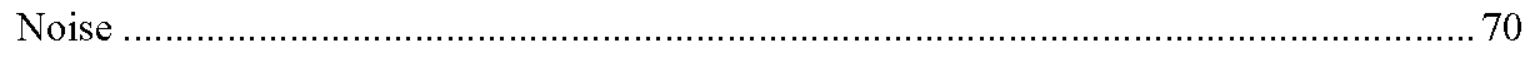

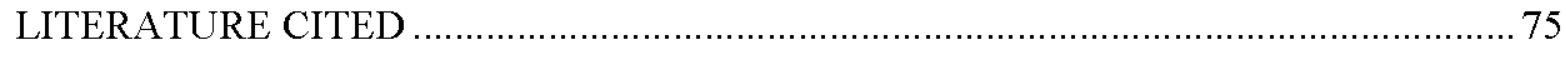

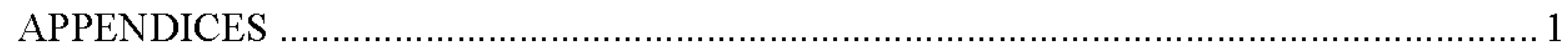

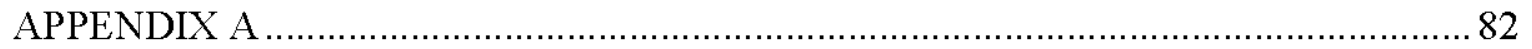




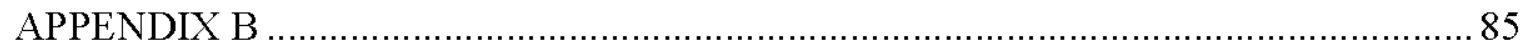

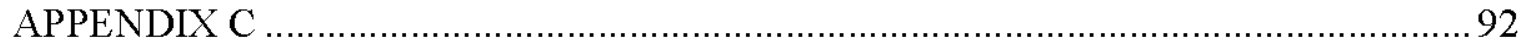

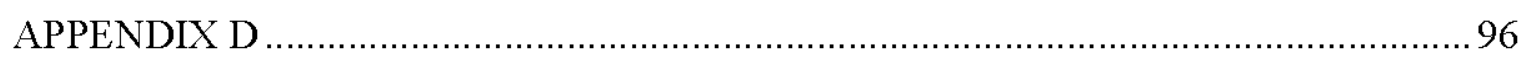




\section{LIST OF TABLES}

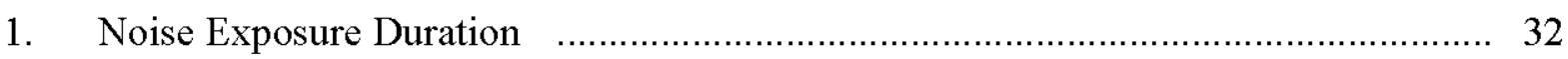

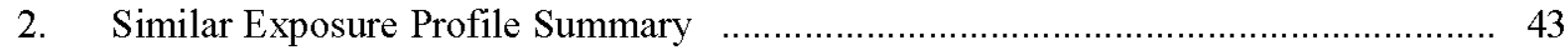

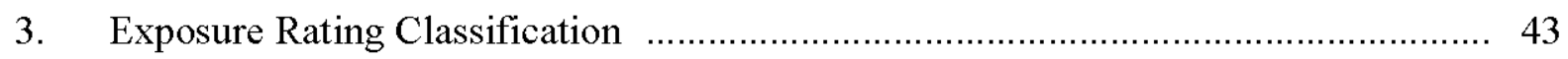

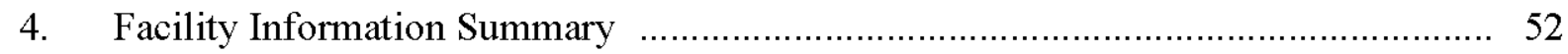

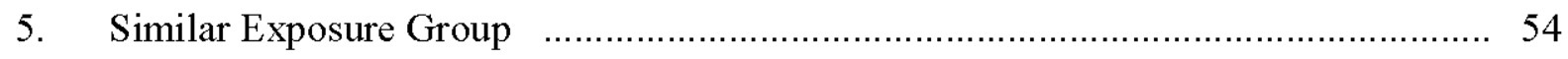

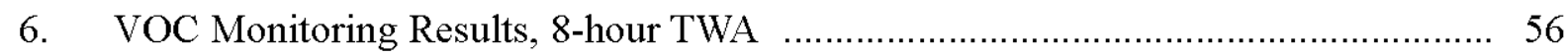

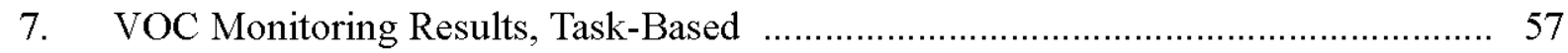

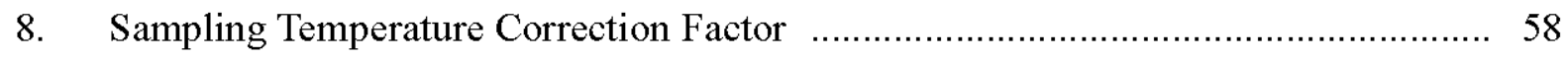

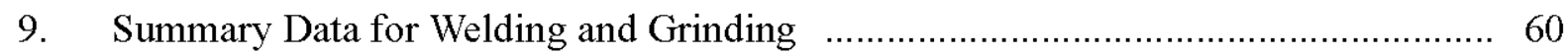

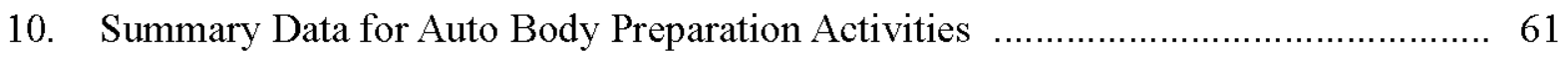

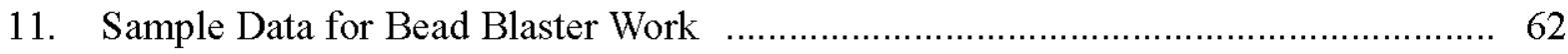

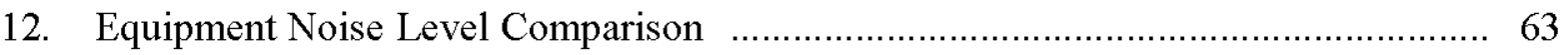

13. Noise Data Summary by Job Classification (8-Hr TWA) ................................ 63

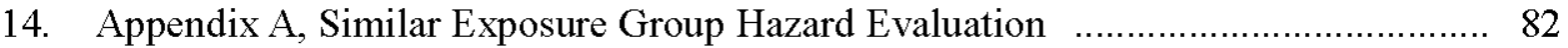

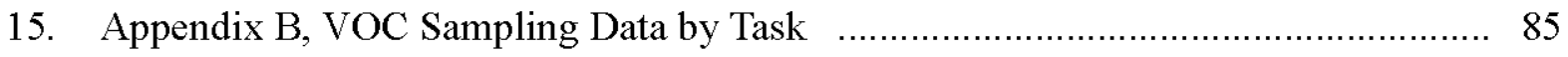

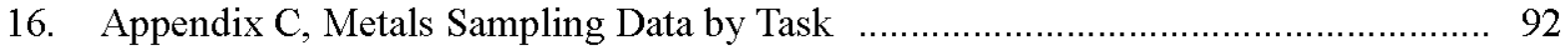

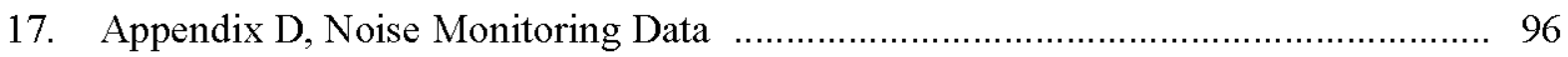


DEDICATION 


\section{INTRODUCTION}

Employers are legally obligated under the Occupational Safety and Health Act to inform their employees of the chemical and physical hazards in their work area and to reduce the potential for exposure and injury per the Occupational Safety and Health Administration (OSHA) regulations (OSHA Standards - 29CFR 2013). The Hazard Communication Standard (HCS) is the general regulation that applies to chemical usage in the workplace (HCS 2013). This standard requires employers to inform and train their employees in the proper recognition, use and handling of hazardous chemicals or products. To minimize workplace exposures, OSHA has also published a list of hazardous chemicals with an occupational exposure limit called the permissible exposure level (PEL) which is the cumulative amount of air contaminant a worker may be exposed to for an eight-hour period (OSHA 2006). To ensure that employees are not being exposed to chemical and physical hazards at levels above the occupational exposure limit, the employer must evaluate the workplace to determine an employee's potential for and extent of exposure and then implement exposure controls. Ideally, personal protective equipment (PPE) should be worn by employees during the evaluation process to reduce exposures until they are characterized and appropriate engineering controls can be implemented.

The work scope for vehicle and equipment mechanics includes servicing, repairing and overhauling the mechanical parts of motor vehicles. These systems include the drive train (engine, transmission, gear box and differential), the suspension (springs, steering, brakes, wheels and tires), and the vehicle body components. The vehicle repair industry tends to specialize and provide limited services. Some mechanic shops specialize in suspension repair, 
while others perform full-spectrum service for light-duty service vehicles and pickup trucks. An entire sub-sector of the automotive industry is dedicated to auto body service and repair. Mechanic shops may also specialize by only providing service for heavy equipment used on construction sites and large trucks used for hauling. Regardless of the type of service provided, all mechanic shops work with similar tools and chemicals and have similar exposure potentials to chemical and physical hazards.

Federal, state, and municipal agencies operate a fleet of vehicles to provide services and manage their operations. Rather than contracting to private service shops, these agencies have mechanics on staff and provide the services in-house. The U.S. Department of Energy (DOE) oversees the cleanup work at the Hanford site. The cleanup operations are performed by contractors who are assigned specific work scope monitored by DOE staff (DOE 2012a). Mission Support Alliance LLC. is the contractor that provides on-site fleet management and maintenance services for vehicles leased by the General Services Administration or owned by the DOE as well as equipment used in support of the Hanford cleanup mission (DOE 2012b). MSA provides service and repair work for construction equipment, light vehicles, heavy vehicles and farm machinery. They are also responsible for forklifts, generators, and air compressors maintenance and repair.

A prior qualitative occupational exposure assessment had been conducted in the fleet services group as required by the DOE Worker Safety and Health Program (DOE Standards 10CFR Part 851.21 2013). The assessment identified physical and chemical hazards in fleet shops that were either considered controlled or that required further assessment. Benzene, 
lead and noise were three hazards identified as needing additional characterization because of the uncertainty of the exposure level and the deleterious health effects from overexposure. Benzene is a persistent contaminant found in many petroleum-based chemical products. Literature suggests airborne exposure to benzene could occur during use of products known or expected to contain benzene in a concentration less than $0.1 \%$ by weight (Kopstein 2006). The potential for exposure to lead could occur during grinding and sanding activities, while working with bead blasting equipment or soldering, and from servicing lead acid batteries. Noise exposures occur during use of pneumatic tools or power tools, from engine noise in the shop, by pounding on metal surfaces, and through the use of equipment for changing tires in the field and in the shop.

\section{Overview of Chemical and Physical}

Depending on the vehicle or equipment component being serviced, a mechanic has the potential for exposure to chemical hazards from solvents, paints, lubricants and greases. They are also subject to exposure to dusts and particulates, in addition to physical hazards such as noise from use of impact wrenches and grinders (Bejan et al. 2011). Aerosol spray cans are the most widely used delivery system for many solvents in mechanic shops (Wilson et al. 2007). The constituents in most non-chlorinated aerosol degreasing solvents include volatile organic compounds (VOCs). VOCs, as a source of exposure, present an episodic inhalation hazard to the product user (Wilson et al. 2007). While several aerosol solvents are manufactured and labeled for a specific vehicle component or system, the products contain many of the same petroleum-derived compounds and are often used interchangeably in repair shops. Other potential VOCs exposures occur during use of parts washers, from vehicle exhaust, and during the use of spray paints and lubricants. 
The common compounds found in degreasing agents and automotive paints used by mechanics include toluene, xylene, ethyl benzene, VM\&P naphtha, and heptane. These petroleum product derivatives likely contain benzene as a contaminant (Van Wijngaarden E. et al., 2003). Benzene occurs naturally in crude oil and natural gas, and low concentrations remain in petroleum-based solvent products following the fractional distillation process (Williams et al. 2008). Benzene is a confirmed carcinogen and exposure in the workplace is regulated by OSHA through 29 CFR Section 1910.1200, the Hazard Communication Standard and Section 1910.1028 under subpart $Z$ for toxic and hazardous substances. Under the hazard communication standard, chemical product manufacturers are required to identify carcinogens on the material safety data sheet (MSDS) when present in the product at $\geq 0.1 \%$ by weight. OSHA also requires the MSDS to identify carcinogenic or toxic agents if components in the mixture could be released in concentrations that could exceed an occupational exposure limit or could present a health risk to employees during use regardless of the concentration in the product (OSHA 1998).

Airborne benzene concentrations measured in the immediate work area of an operating parts washer containing a solvent with $0.058 \%$ benzene by weight led to 1 hour average exposures that approached the permissible exposure limit (PEL) (Fedoruk et al. 2003). Petroleum-derived solvents that include toluene, xylene, VM\&P naptha, hexane, heptane, and ethyl benzene could contain trace amounts of benzene that would not be identified on a product MSDS because the concentration would likely be less than $0.1 \%$ by weight (Kopstein 2006). However, use of the products could expose employees to airborne benzene 
concentrations that exceed the occupational exposure limit such as the American Conference of Governmental Industrial Hygienists, (ACGIH) threshold limit value (TLV) and OSHA's PEL depending on the amount of product used and the concentration of benzene in the product (Kopstein 2006). TLVs are not OSHA derived standards but are published guidelines established by a private research organization,

Exposures to dusts and particulates can occur from work on brakes and clutches or during surface sanding, grinding, welding, and during auto body work involving body filler compounds (Enander et al. 2004). The auto repair and refinishing industry has been associated with a high risk of exposure to lead from handling batteries, radiator repair and from mechanical paint removal. Paint products manufactured for use on vehicles have been shown to contain as much as $60 \%$ lead by weight after application of the paint (Blando et al. 2007). The most commonly reported lead exposures not associated with the construction trades include electronics soldering, automotive and radiator repair, and the sanding, cutting, or welding on or near painted metal surfaces (Nelson et al. 1998).

Although chemically-based paint strippers are available, the typical method used to remove paint from vehicles or equipment is a hand-held orbital sander. The use of powered sanding tools can generate significant amounts of airborne dust that can adhere to skin or be inhaled. Sanding dust containing paint pigments or other metals can also deposit onto other surfaces that become a potential source of contamination when not cleaned. Because most mechanics fail to test the paint for lead or other hazardous metals before they begin removing it, they are also unlikely to use personal protective equipment (PPE). Their work habits create 
an increased risk of exposure to lead dust. Laboratory analysis of dust samples from several auto body repair shops confirmed that lead was present in all of the paint dust samples and almost $50 \%$ of the body filler dust samples (Enander et al. 2002).

Excessive noise is a hazard that afflicts the majority of work settings outside an office environment. In the United States, more than 30 million workers are exposed to hazardous noise levels sufficient to cause hearing loss especially in occupations associated with manufacturing, transportation, mining, construction, agriculture, and the military (ConchaBarrientos et al. 2004). Vehicle repair shops use a wide range of powered and non-powered tools including pneumatically-driven air tools including grinders, sanders, ratchets, and cutoff wheels in addition to welding equipment and hand tools. During use of these tools, a mechanic could be exposed to hazardous noise sources without the benefit of engineering controls or adequate hearing protection. The risk of overexposure is often unrecognized because many work tasks are of short duration but may occur frequently throughout the workday. For example, the ACGIH maximum exposure guideline for a noise level of 100 decibels $(\mathrm{dB})$ during an 8-hour workday without the use of hearing protection is 15 minutes. This noise guideline was set to minimize damage to the inner ear and noise-induced hearing loss (ACGIH 2012). According to the OSHA regulation 29 CFR 1910.95(b)(2 ) an employee could work for two hours at a noise exposure level of $100 \mathrm{~dB}$ without hearing protection, presuming the employee did not receive additional noise exposure for the remainder of the workday. 


\section{Objectives}

Given the recommendations for further study of hazards identified in the fleet services assessment, this thesis is a follow-on study of fleet services workers potential for exposure to benzene, lead dusts and noise. This study characterizes the risks from exposure to these regulated hazards and suggests the implementation of suitable control measures. The principle objectives of this study were:

1. Define a similar exposure group category (SEG) for the three selected environmental agents. Categorizing employees into similar exposure groups is a method used by occupational health professionals for evaluating the exposure potential of employees. Employees are grouped by similarity of work tasks, work location, physical hazards, chemical hazards, and frequency and duration of potential exposure.

2. Conduct exposure monitoring within each of the similar exposure groups for the agents of concern. Breathing zone air samples were collected and analyzed for benzene and lead dusts, and noise levels were monitored in the work area with personal noise dosimeters. Full-shift sampling was the preferred method to establish a time weighted average exposure to noise and benzene. Task-based sampling was used to evaluate worstcase exposures for lead dust.

3. The exposure profiles for the three environmental agents developed from the sampling data and work activity observations were used to characterize risk as below or above the 
levels of concern. The exposure profile is a summary of the exposures experienced by a similar exposure group and includes an understanding of the variability of the exposures.

This thesis is presented with the relevant sections necessary for publication of a manuscript in the Journal of Occupational and Environmental Hygiene. A manuscript is not included as part of this thesis and will be presented for publication at a later date. 


\section{LITERATURE REVIEW}

\section{Occupational Exposure Assessment}

Vehicle and equipment mechanics perform a variety of work tasks that can be a source of exposure to chemical and physical hazards. The extent of employee exposure must be evaluated and depending on the degree of exposure, engineering controls or personal protective equipment must be implemented to reduce exposures to levels as low as feasible or at least to below the mandated occupational exposure limit (OEL).

The book titled "A Strategy for Assessing and Managing Occupational Exposures", written by professional members of the American Industrial Hygiene Association (AIHA), provides an accepted method used by occupational safety and health professionals to conduct a comprehensive evaluation of occupational exposures using the concept of similar exposure groups (Ignacio et al. 2006). A comprehensive exposure assessment requires an understanding of the work environment and processes leading to employee exposures. Exposure assessments describe the nature and size of the various worker populations, and the magnitude and the duration of their exposures (Paustenbach 2000). The best method to fully evaluate employee exposures would include regular sampling in the work environment for the hazards of concern. Constrained by limited budgets, time, and resources, the feasibility of quantitatively evaluating all exposures for every employee is unlikely. As a result, a qualitative assessment is often the first and sometimes only attempt at exposure assessment by some employers (Elliot et al. 2007). 


\section{Qualitative Exposure Assessment}

A qualitative evaluation is the initial step used to evaluate potential employee exposures and requires a substantial amount of information to be gathered about the work area, work tasks, processes, and chemical usage including any by products. Sources of information include the material safety data sheets, chemical inventory reports, and site visits. Field observation is important to establish the frequency and duration of chemical usage, and to identify other potential exposure hazards such as noise or biological agents. An evaluator also conducts employee interviews and reviews past sampling data. During the site visit, it is important to document any chemical or physical hazards observed and the frequency and duration of exposure, the use of exposure controls, actual work practices and processes, and the number of employees and the length of their work shift.

Using the information collected, an industrial hygienist could estimate the potential exposure to the hazards in the work place for a single employee or a group of employees by classifying them into similar exposure groups. A similar exposure group (SEG) consists of workers that perform the same or similar work tasks and thus would be expected to have similar frequency and duration of exposures to chemical or physical hazards (Kopstein 2006).

Models are one method used to estimate occupational exposures. Relatively simple models assume steady state concentrations rather than concentration changes over time (Ignacio et al. 2006). For example, a simple physical chemical inhalation model estimates the toxicant concentration in the air and assumes that workers are breathing the same air with the estimated concentration (DiNardi 2003). Modeling software is another method used to 
qualitatively evaluate the potential for worker exposure. The QLEA software model was developed to evaluate the risk of exposure from inhalation, dermal and ingestion routes (Elliot, et al. 2007). Modeling software uses parameters such as monitoring results of other agents, previous exposure monitoring for the same agent used at other processes or statistical models that include parameters thought to affect the exposure concentrations. The objective of modeling is to classify the exposures into categories that are based on the frequency and duration of the chemical usage, the toxicity of the chemical, and the exposure reduction controls. Computer models of estimated parameters are attractive due to ease of use and favorable cost structure over a quantitative assessment (Elliot et al. 2007). The cost of collecting personal exposure samples and the associated laboratory analysis fees are eliminated, and the lack of direct monitoring is far less disruptive to production. But qualitative methods are less accurate and leave the potential for employees to be exposed to hazardous chemicals and noise levels (Elliot et al. 2007). The inhalation risk factor of a qualitative exposure assessment model was compared with quantitative exposure data for 24 chemical agents from a manufacturing facility. The model accurately classified measured exposures in only $51 \%$ of the cases with an overall probability of $47 \%$ for overestimating exposure (Elliot et al. 2007).

\section{Quantitative Exposure Assessment}

A quantitative exposure assessment is considerably more costly and time consuming than the qualitative assessment but it is also an objective and more accurate method. After collecting information during the qualitative evaluation, a sampling plan is developed to measure worker exposures. Sampling can be scheduled to evaluate the worst-case exposures when levels are expected to be above the OEL. However, this data could not be used to 
estimate the average exposure for the workers. The decision process used to identify the higher exposures may introduce bias in the sample results. Worst-case sampling relies on the occupational hygienist to recognize the environmental conditions and work practices that affect employee exposures (Spear 2005).

Using a random sampling process to determine the average exposure eliminates biases of judgments about job condition, work practices or other conditions believed to have an impact on the exposure (Spear 2005). Random sampling is more likely to capture the variability in the work practices between workers, tasks and days and can be used to measure the average exposure for all workers on all days. In most workplaces, it is difficult to measure exposures for every worker (Ignacio et al. 2006). Randomly selecting a small subset of workers from similar exposure groups allows an accurate extrapolation to all employees in these groups through application of univariate statistics (e.g., central tendency and variance) (Spear 2005).

\section{Occupational Exposure Limits}

Federal and state regulatory agencies have determined legally enforceable occupational exposure limits (OELs) for several hundred chemical, biological, and physical agents. OSHA sets regulatory permissible exposure limits (PEL) on the airborne concentration of a substance based on an 8-hour time-weighted average exposure in the work environment. These limits may also contain a "skin" designation if the chemical can be readily absorbed through the skin (OSHA 2006). The "skin" designation refers to the potential significant contribution to the overall exposure by the cutaneous route including mucous membranes and eyes (ACGIH 2012). The goal of OSHA's PEL is to assure that every employee would have 
safe and healthful working conditions that protect against diminished health, functional capacity or shortened life expectancy (DiNardi 2003). Most of the PELs were determined using the most relevant exposure data around 1970 when OSHA was created. The PELs are enforceable by OSHA for all employers.

The National Institute for Occupational Safety and Health (NIOSH), which is part of the Centers for Disease Control and Prevention in the U.S. Department of Health and Human Services, publishes the recommended exposure limits (RELs) that serve as the scientific basis for the information used by OSHA to set new PELs or for changing existing PELs. The RELs and accompanying comprehensive toxicology information may also be used by industry to set exposure limits (DiNardi, 2003). The ACGIH is a member-based professional society that publishes TLV exposure limits that are recommendations or guidance limits used by occupational hygienists in making decisions regarding safe levels of exposure to various chemical and physical agents found in the work place (ACGIH 2012). The NIOSH RELs and ACGIH TLVs are not enforceable under the law, but unlike regulatory limits, they can be readily lowered when new scientific research indicates a change is necessary to reduce the exposure risk.

In general, OELs suggest levels of exposure for up to 8 or 10 hours per day or 40 hours per week for a working lifetime unlikely to be associated with adverse health effects. Exposure limits do not represent a fine line between safe and unsafe because reactions to exposures below the OEL will be influenced by individual susceptibility due to pre-existing medical conditions or hypersensitivity (ACGIH 2012). In addition, some hazardous 
substances may act in combination with other workplace exposures, the general environment or with medications or personal habits of the worker to produce adverse health effects even if the occupational exposures are controlled at or below the exposure limit (Almaguer 2008).

\section{Measuring Employee Exposures to Chemicals}

Integrated sampling covering the entire period of exposure is required because airborne contaminant concentrations during a typical work shift vary with time and activity (DiNardi 2003). Personal air sampling is the preferred method to evaluate employee exposure to airborne contaminants (Plog et al. 1996). A small air pump is worn by an employee and connected to the sampling media by a piece of non-reactive tubing. The air pump draws a known volume of air through the sampling media that is attached to the person's lapel within $15-23 \mathrm{~cm}(6-9 \mathrm{in})$ of their nose and mouth, which is considered the breathing zone. An air sample obtained within a person's breathing zone is representative of the airborne contaminant concentrations to which they were exposed through inhalation.

Selection of the sampling media is determined by the physicochemical properties of the contaminant being sampled and the analytical method used by the laboratory. As metal particles or chemical vapors move through the tubes packed with the sampling media, they are sorbed in the filter or within the matrix of the sorbent. Benzene is sampled by pulling air through tubes filled with coconut-shell charcoal, which is an amorphous form of carbon that has a large reactive surface area and high adsorptive capacity (Plog et al. 1996). Benzene can also be sampled by trapping on passive sampling badges. The air contaminant of interest diffuses across a membrane at a chemical-specific rate and is collected on a sorbing medium such as charcoal that is protected by a barrier to prevent the influence of ambient air 
movement on trapping efficiency (DiNardi 2003). OSHA has published a validated sampling and analysis procedure, Method 1005, for both active and passive airborne benzene concentrations. The accuracy of the procedure at the $95 \%$ confidence interval is $\pm 9.94 \%$, which includes $5 \%$ for sampling error. The accuracy of the $3 \mathrm{M} 3520$ passive organic vapor dosimeter badges is $12 \%$, when both temperature and pressure are recorded at the time of sampling (OSHA 2002).

\section{BENZENE}

\section{Health Effects of Benzene Exposure}

Numerous animal studies have been conducted to determine the effects of acute and chronic exposure to benzene through inhalation, absorption and ingestion. In addition, epidemiological cohort studies have evaluated exposure records in an effort to confirm the carcinogenicity of benzene from industries and job groups where exposure to benzene was known to occur.

At a dose of $50-500 \mathrm{mg} / \mathrm{kg}$ bw, benzene can act as an acute poison to humans by producing a narcotic effect, and inhalation of approximately $2 \%$ in air for 5 to 10 minutes can be fatal. Metabolism studies have shown that approximately $46 \%$ of benzene that is inhaled is absorbed into the body whereas only $0.05 \%$ is absorbed from the skin (ACGIH 2001).

Acute exposure to high concentrations of benzene may depress the central nervous system, leading to unconsciousness. However, the major effect of high dose exposures is

hematopoietic toxicity (Klassen 2008) Chronic exposure to benzene in the workplace leads to 
bone marrow damage which may be manifested initially as anemia, leucopenia, or thrombocytopenia and may progress to myelogenous leukemia (Klaassen 2008).

Benzene is a myelotoxicant, known to suppress bone marrow cell proliferation and to induce hematologic disorders in humans and animals. Signs of benzene-induced aplastic anemia include suppression of leukocytes, red cells, or platelets or of all three cell types (ACGIH 2001). The Environmental Protection Agency (EPA) has classified benzene as a known human carcinogen and has noted that epidemiological studies and case studies provide clear evidence that benzene exposure affects the blood forming cells in adults leading to acute nonlymphocytic leukemia, chronic nonlymphocytic leukemia and chronic lymphocytic leukemia. Data from animal studies has provided evidence that benzene exposure is also associated with other blood disorders including preleukemia, aplastic anemia, Hodgkin's lymphoma and myelodysplastic syndrome (IARC 1999).

The World Health Organization International Agency for Research on Cancer (IARC) has classified benzene as a known human carcinogen since 1980. The classification was based on epidemiological studies showing a causal association between comparatively high occupational benzene exposures to the development of acute myelogenous leukemia. Chronic exposure was associated with an increased risk of developing total lymphatic and hematopoeietic cancer, total leukemia and specific histologic types of leukemia including chronic lymphocytic leukemia (NTP 2011). 
The mechanism of benzene induced toxicity appears to involve the action of several benzene metabolites. The ortho and para benzoquinones are believed to be among the ultimate toxic metabolites of benzene. Another potentially toxic metabolite, muconaldehyde, may arise from ring opening of benzene oxide (Klaassen 2008).

\section{Benzene Regulations}

Occupational exposure to benzene is regulated by OSHA through a standard written for all industries that use or manufacture benzene, or use products that contain benzene (OSHA Standard - 29 CFR 1910.1028). The standard requires that employers implement a medical monitoring program for employees who are exposed to one half of the OSHA PEL for 30 or more days per year. OSHA has set the permissible exposure limit for airborne benzene concentrations to 1 part per million (ppm) for an 8-hour work day, with a short term excursion limit (STEL) exposure set to a maximum of at $0.5 \mathrm{ppm}$ for a 15 minute exposure time. The ACGIH is more conservative and set the TLV for an 8-hour work day at $0.5 \mathrm{ppm}$ and the STEL at $0.25 \mathrm{ppm}$.

The lower exposure limits set by the ACGIH are based on an analysis of sampling data conducted by NIOSH on a cohort that involved documented benzene exposures at levels as low as $4 \mathrm{ppm}$. The ACGIH exposure limit recommendation has been in effect since 1946 and was initially set at $100 \mathrm{ppm}$. By 1975 , benzene was listed as a suspected human carcinogen and the TLV had decreased to $10 \mathrm{ppm}$. In 1990 benzene was listed as a confirmed human carcinogen and the proposed TLV was lowered to $0.1 \mathrm{ppm}$ but was eventually raised to 0.5 ppm (ACGIH, 2001). 
OSHA also regulates occupational exposures to benzene through the Hazard Communication Standard (OSHA Standard - 29 CFR 1910.1200), which requires manufacturers of products containing carcinogenic constituents such as benzene to list these ingredients on the material safety data sheet for substance with a concentration $\geq 0.1 \%$ by weight. The Hazard Communication Standard also requires manufacturers to list carcinogenic products on the MSDS if the components in a mixture could be released in concentrations that would exceed the OSHA PEL or ACGIH TLV, or present a health risk to employees using the product even if the product contains carcinogenic chemicals $<0.1 \%$ by weight (OSHA, 1998).

\section{Use and Sources of Exposure}

For many years, benzene was considered an important solvent which was used in the manufacture of inks, rubber materials, lacquers and paint removers. Today, because of the toxic effects of benzene, it is still used in the manufacture of those products but in smaller quantities (ACGIH 2001).

Benzene is currently used primarily as a solvent in the chemical and pharmaceutical industries as a starting material and intermediate in the synthesis of numerous chemicals including the production of ethylbenzene, phenol, acetone, cyclohexane, nitrobenzene, detergent alkylate and chlorobenzene (ASTDR 1997). Benzene is also used in the manufacture of dyes, plastic resins, some explosives, and as a solvent for waxes, resins, oils and natural rubber. Gasoline contains benzene approximately $2 \%$ by volume (Van Wijngaarden et al. 2003). 
Organic solvents such as toluene have been used for the past several years as a replacement for benzene in the manufacture of many products (Williams et al. 2007). However, because benzene is considered a persistent contaminant in petroleum products, it has been found in many refined petrochemicals such as VM\&P naphtha, Stoddard solvent, xylene, toluene, hexane and 140 flash aliphatic solvent ranging in concentrations from less than 700 ppm up to 10,000 ppm (Kopstein 2006).

Solvents used in the vehicle repair industry such as petroleum naphthas, gasoline, aliphatic solvents and solvent products containing toluene and xylene are generic mixtures that could contain benzene. Auto mechanics may be exposed to benzene while working with fuel systems, exchanging fuel filters, fuel pumps, adjusting valves, using aerosol solvents, or working in an area where vehicle exhaust could accumulate (Van Wijngaarden et al. 2003, Badjagbo et al. 2010).

The benzene content of petroleum-derived products has declined significantly after the late $1970 \mathrm{~s}$ and early $1980 \mathrm{~s}$ and is now less than $0.1 \%$ volume/volume (v/v) for commercial products (Williams et al. 2008). Products used in the workplace that contain carcinogenic chemicals at a concentration less than $0.1 \%$ would not be expected to present an exposure hazard under normal use and the carcinogenic constituents are not required by law to be identified on the MSDS. The airborne benzene concentration can be calculated using Raoults law of partial pressures based upon the amount of benzene in the base solvent but this estimation ignores the ventilation rate and localized air movement or mass of material used (Robbins et al. 2012). Mineral spirits are mixtures of petroleum-derived hydrocarbons that 
often contain benzene at $0.1 \% \mathrm{wt} / \mathrm{wt}$ or less. Assuming partial evaporation of mineral spirits and an evaporation rate constant of $0.105 \mathrm{hr}^{-1}$, the predicted benzene air concentration could exceed the OSHA TWA of 1 ppm (Kopstein 2011).

Peak and time-weighted average airborne benzene concentrations have been evaluated in a worker's breathing zone during use of a recycled mineral spirits product in an open metal parts washing tank (Fedoruk et al. 2003). The parts washer was set up in a large warehouse approximately $60 \mathrm{~cm}$ from an inside wall with no additional ventilation other than 2 garage doors that remained open during the study period. Mineral spirits containing $58 \mathrm{ppm}$ was poured into the open parts washer tank and air samples were collected for a one-hour time frame at a distance $91 \mathrm{~cm}$ above the solvent. Sample data obtained from this study suggests that products containing benzene at a concentration well below the OSHA threshold of $0.1 \%$ wt/wt may lead to worker exposures approaching the OSHA occupational exposure limit of 1 ppm on a transient basis (Fedoruk et al. 2003) Elevated exposures would be short lived because trace levels of benzene in a solvent diminish with repeated use (Fedoruk et al. 2003) Studies that monitor the benzene concentrations in air under different workplace scenarios could be useful for qualitative assessment models. However, the general applicability of such data to a qualitative assessment model is influenced by specific conditions, such as benzene content in the solvent, frequency and duration of solvent use, and distance between breathing zone and source. (Kopstein 2006). Exposure predictions from qualitative assessment models tend to be "order-of-magnitude" estimates rather than fine characterizations of exposures therefore; the data should be interpreted with caution (Ignacio et al. 2006) 
Potential benzene exposure has been measured from use of penetrating solvents and lubricants. In particular, airborne benzene was measured from the use of Liquid Wrench formulations (Williams et al. 2007). The manufacturer of this product was involved in litigation related to potential benzene exposure, so a simulation study was designed to retrospectively estimate air residues from different scenarios during non-aerosol use to loosen nuts and bolts. The study took place in a household garage which had one window and a two car garage door that remained closed. Each simulated test was set up to be able to compare the airborne concentrations of benzene in relation to the amount of product used, the mass of benzene in the product and the number of air exchanges that took place inside the garage. The highest exposure of $2.7 \mathrm{ppm}$ was obtained from a 15 minute sample using $10 \mathrm{ml}$ of product containing benzene at $3 \%$ volume/volume (v/v) (Williams et al. 2007). The 8-hour TWA would be $0.08 \mathrm{ppm}$ assuming no additional exposure for the remainder of the work day. However, assuming the worker performed the same task with similar airborne concentrations 6 times during the day, the 8 hour ACGIH TLV could be exceeded.

The toxic effects of benzene exposure are well documented at moderate to high exposure levels (EPA 2002). Benzene exposures at levels $<1 \mathrm{ppm}$ have been shown to cause hematologic effects (Lan et al. 2004). Benzene is a ubiquitous environmental air contaminant which comes from many sources including forest fires, chemical manufacturing, petroleum refining and processing, and vehicle emissions, and people are exposed daily to low environmental levels in addition to the exposures at their workplace. For example ambient air benzene concentrations obtained in the early 1990s at gasoline service stations were reported 
as high as $0.5 \mathrm{ppm}$. Following installation of stage II vapor recovery systems as part of the clean air act, reported ambient air concentrations were $0.14 \mathrm{ppm}-0.18 \mathrm{ppm}$ (Periago 2003)

Airborne BTEX (benzene, toluene, ethyl benzene and xylene) concentrations have been measured inside motor vehicle repair shops during regular working hours and normal activities (Badjagbo et al. 2010). The workplace contributed 64-79\% of mechanics daily benzene exposure. Exposures for non-cancer effects were well below OELs but risk for cancer was elevated even though maximum air concentrations of benzene were only $0.07 \mathrm{ppm}$ (Badjagbo et al. 2010).

VOCs other than benzene have been monitored in vehicle repair shops. Based on airborne residues of hexane, acetone, toluene, and total VOCs, episodic exposures could occur to mechanics using aerosol products of non-chlorinated solvents (Wilson et al. 2007). The proportions of the VOCs in the breathing zone were similar to those found in the bulk products used by the mechanics.

Collecting personal air samples within a worker's breathing zone is the most common method to evaluate exposure to airborne contaminants and thus is required by regulations. Biological monitoring can be used to assess total contaminant dose because it integrates all routes of exposure, and most importantly for workers, skin absorption (ACGIH 2012). The Blood, exhaled air, and/or urine are typical biological samples, but a medical professional must collect them following an actual or perceived exposure. Urinary metabolites such as $\mathrm{t}, \mathrm{t},-$ muconic acid and S-phenylmercapturic acid are accepted biomarkers of benzene exposure 
(ACGIH 2001). However, this determinant may also be present in biological specimens collected from subjects who have not been occupationally exposed which could affect the interpretation of the result (ACGIH 2012). Benzene metabolite values following environmental exposures below $0.1 \mathrm{ppm}$ showed muconic acid levels that indicated evidence of benzene exposure other than background sources (Rappaport et al. 2010).

One comparatively non-invasive method for biological exposure monitoring involves measuring contaminants in worker breath. Benzene concentrations in automobile mechanics' breath were measured on three occasions during the course of one year (Egeghy et al. 2002). Mechanics were likely exposed to benzene during use of aerosol degreasing solvents or when working with the vehicle fuel system. Significant linear correlations between benzene in ambient air and worker breath suggested that exhaled air samples would be as effective as personal air monitoring for exposure assessment.

\section{LEAD}

\section{Health Effects of Lead Exposure}

The effects of lead exposure are the same whether it enters the body through inhalation or ingestion. The main target for lead toxicity in adults and children is the nervous system (ASTDR 1997). Adults absorb 5-15\% of ingested lead and usually retain less than 5\% of what is absorbed whereas children absorb $42 \%$ of ingested lead with $32 \%$ retention (Klaassen 2008). When lead gets into the body, it first goes to the bloodstream where it has a half-life of approximately 30 days (Klaassen 2008). Lead that remains in the bloodstream

will eventually be excreted via the kidneys and liver. However, continued lead exposure could increase the blood lead level if intake is greater than depuration (Klaassen 2008). 
The lead that is not excreted from the body accumulates in the bone, teeth and hair. Storage in the bone accounts for over $90 \%$ of the lead body burden with a half-life of approximately 20 years (Klaasen et al. 1999) Lead that accumulates in the bone can substitute for calcium and has been shown to affect the bone osteoblasts, osteoclasts and chrondrocytes which may promote osteoporosis and also delay fracture repair (Klaassen 2008). With continued exposure, the health risk is increased without the ability to determine the preexisting lead body burden (ASTDR 2007). A person's lead body burden can vary with their age, health status, and nutritional state indicating the lack of a threshold. For these reasons, the EPA has not developed reference values for lead exposure (IRIS 2011).

Accumulation of lead in the body has been associated with an increase in blood pressure, anemia and renal toxicity (nephropathy) for persons who have blood lead levels ranging from $40-100 \mu \mathrm{g} / \mathrm{dl}$ and have been exposed to lead for more than 10 years (ACGIH 2001). Chelating agents have been used to reduce acute lead nephrotoxicity, however, chronic nephrotoxicity can lead to renal failure from nephron loss (Klaassen 2008). Chronic exposure to lead has also been associated with peripheral neuropathy such as weakness in fingers, wrists and ankles (ADTDR 2007). Footdrop and wristdrop were the classical manifestations of lead toxicity observed in house painters during the early twentieth century (Klaassen 2008).

In 2006, IARC changed the classification of inorganic lead from "possibly carcinogenic" to "probably carcinogenic" in humans (IARC 2012). The reclassification was based on sufficient evidence of carcinogenicity in animal studies and limited evidence of 
carcinogenicity from human studies (Toxnet 2011). Lead exposure has been associated with an increased risk of stomach cancer in human populations associated with occupations and industries with known lead exposure (Rousseau et al. 2007). The mechanisms by which lead causes cancer are not understood. Lead compounds do not appear to cause genetic damage directly, but may do so through several indirect mechanisms, including inhibition of DNA synthesis and repair, oxidative damage, and interaction with DNA-binding proteins and tumor-suppressor proteins (NTP 2011).

\section{Lead Exposure Regulations}

OSHA regulates exposure to airborne lead concentrations from metallic lead, inorganic lead compounds and organic lead soaps to prevent adverse health effects for most workers throughout a working lifetime. The regulation specifies an action level of $30 \mu \mathrm{g} / \mathrm{m}^{3}$ and a PEL of $50 \mu \mathrm{g} / \mathrm{m}^{3}$ both averaged over an 8-hour workday. These exposure limits are intended to maintain a person's blood lead level at or below $40 \mu \mathrm{g} / \mathrm{dl}$ (OSHA Standard - 29 CFR 1910.1025). If an employee's blood lead level reaches $50 \mu \mathrm{g} / \mathrm{dl}$ of blood, the employee must be removed from the exposure source and have their blood tested regularly until their blood lead level is reduced to a level below $40 \mu \mathrm{g} / \mathrm{dl}$.

OSHA requires employers covered by the lead standard to evaluate the work environment for potential employee lead exposure. The evaluation is done through air sampling conducted in work areas where airborne lead may be present. If the initial air sampling measurements are below the action level of $30 \mu \mathrm{g} / \mathrm{m}^{3}$ 8-hour TWA, the employer must document the results, provide employee training on the OSHA regulation for occupational lead exposure and implement hygiene practices. Airborne sample concentrations 
that are above the action level require the employer to implement periodic exposure monitoring, enroll employees in a medical surveillance program, and provide training on the health effects.

Airborne concentrations that are above the PEL must be reduced below that level through the use of engineering controls, administrative controls and respiratory protection. Regardless of the airborne lead levels, surfaces must be maintained as free as practicable of lead accumulations. OSHA, however, does not specify a regulatory limit to determine the cleanliness of surfaces.

NIOSH and the ACGIH have also published exposure guidelines for airborne lead concentrations that are the same as the OSHA PEL. The intent of the NIOSH REL was to maintain employee blood lead levels below $60 \mu \mathrm{g} / \mathrm{dl}$ of whole blood whereas the lower ACGIH TLV was set to maintain employee blood lead levels below $30 \mu \mathrm{g} / \mathrm{dl}$ (Almaguer et al. 2008).

\section{Use and Sources of Exposure}

Lead is an abundant metal with properties that allow it to combine with other materials to form both soluble and insoluble compounds. These properties include a low melting temperature, malleability, and resistance to corrosion. In 2006, 8 million tons of lead and lead compounds were used worldwide with approximately $71 \%$ used in lead-acid storage batteries and approximately $12 \%$ as inorganic lead used in pigments for paint (Rousseau et al. 2007). Lead has been used in paint pigments for over 200 years as white lead, red lead, and 
oxychloride or Turner's yellow (IARC 2006). Lead compounds can also be found in primers, paint driers, dyes and ceramic glazes.

Other common uses for lead include cable sheathing, lead weights, as a bearing metal for machinery, in the manufacture of brass and bronze and as sheet lead (NTP 2003). Lead compounds are also used as shielding materials for radiation sources, in solder for copper water pipes, and in ammunition (Klaassen 2008). Where less toxic alternatives have become available, the amount of lead used in many products has been significantly reduced or totally eliminated. For example, interior plumbing and solder made before 1930 was mostly lead but has since been replaced with copper pipes and lead-free solder (ATSDR 2011). However, copper pipes may contain up to $8 \%$ lead and the lead-free solder may contain up to $2 \%$ lead (ATSDR 2011). There are still manufacturing processes that use a considerable amount of lead because of the lack of a suitable substitute. Paints that must resist fading and discoloration from exposure to sunlight such as vehicle paints, road paints and road signs have typically contained lead and other metallic pigments (Blando et al. 2007).

While lead in many of the newer coating systems has been reduced or eliminated, some of the older automotive paints may still pose a hazard (Enander et al. 2004). Composite sanding dust samples of original equipment manufacturing (OEM) paint from more than 200 vehicles were collected and analyzed for total metals following EPA procedures for characterizing solid waste. The sampling data indicated that many hazardous metals were present in varying amounts including lead, with the median concentration of $575 \mathrm{ppm}$ (Enander 2002). In a follow-on study, worker airborne exposure to total dusts, and lead dusts 
were evaluated in three auto body repair shops. Air samples were collected during use of ventilated sanding equipment and non-ventilated sanding equipment. Sampling results for the total dust samples were similar between the non ventilated and the ventilated sanding equipment which ranged from $0.62 \mathrm{mg} / \mathrm{m}^{3}$ upwards to $12 \mathrm{mg} / \mathrm{m}^{3}$ (Enander et al. 2004). Airborne lead concentrations were below the OSHA Action level with the exception of one sample which was $0.12 \mathrm{mg} / \mathrm{m}^{3}$ during use of the ventilated sander (Enander et al. 2004). Overall, the sampling data from this study suggested that a potential for exposure to airborne lead particulates does exist even with the use of a ventilated sander that is designed to move dust away from the worker's breathing zone.

Lead exposure remains a significant health concern despite policies and practices that have resulted in continued progress toward reducing exposure and lowering blood lead levels in the United States (NTP 2003). Lead is used extensively to make automotive battery terminals, the anode and cathode plates and the lead pastes used to coat the plates (Blando et al. 2007).

Mechanics have a potential for lead exposure when working with lead-acid batteries, repairing radiators, during mechanical paint removal and to a lesser extent from lead weights used to balance vehicle wheels. Metallic lead articles form a coating, when exposed to air. The lead oxide coating protects the metal underneath from further oxidation and is similar to a fine dust that can present an inhalation or ingestion hazard. 


\section{NOISE}

\section{Health Effects of Occupational Noise Exposure}

Exposure to hazardous noise will initially cause a temporary shift in a person's ability to hear. This decreased hearing sensitivity typically returns to its former level within a short period of time after the person is no longer exposed to the noise source (NIOSH 1998). Repeated exposure to high noise levels has been associated with a permanent threshold shift referred to as noise induced hearing loss (NIHL) (NIOSH 1998). NIHL can occur from a single exposure to a noise source that immediately damages the nerve cells in the inner ear resulting in permanent hearing loss. More commonly, hearing loss occurs over time to repeated high noise exposure.

The ability to hear declines with age in all populations. NIHL is an irreversible sensorineural condition that progresses with exposure and produces greater hearing loss than what is experienced through the aging process alone (NIOSH 2008). Hearing loss from occupational noise exposure is gradual and occurs predominantly in the higher frequencies $3000-6000 \mathrm{Hertz}(\mathrm{Hz})$ with the largest effect occurring at $4000 \mathrm{~Hz}$ (Concha-Barrientos et al. 2004). With continued exposure to noise, hearing loss will move to the lower frequencies of 500,1000 and $2000 \mathrm{~Hz}$ (ACGIH 2001).

Noise exposure has been linked to annoyance, hypertension, ischemic heart disease and hearing impairment (Passchier-Vermeer et al. 2000). Hearing impairment is the best characterized health effect with a clear mechanistic pathway between the physical properties of noise and damage to the hearing system (Concha-Barrientos et al. 2004). The loss of 
hearing can greatly impact communication as the ability to hear certain speech sound is diminished (NIOSH 2008). Normal speech falls in the $500-4000 \mathrm{~Hz}$ range with vowels falling in the lower frequency range and consonants in the higher frequency range (Berger 2003). For example, hearing loss beginning at $2000 \mathrm{~Hz}$ can impair a person's ability to hear the difference between the words fish and fist (Berger 2003). Epidemiological studies that have compared the prevalence of hearing loss with noisy occupations have suggested a strong association between occupational noise exposure and noise induced hearing loss (ACGIH 2001).

\section{Noise Exposure Regulations}

OSHA 29 CFR 1910.95 Occupational Noise Exposure specifies and action level of 85 $\mathrm{dB}$ and a permissible exposure limit of $90 \mathrm{~dB}$ for an 8-hour TWA. Noise exposure at the action level requires employers to administer a hearing conservation program. This program consists of employee training, noise monitoring, audiometric testing, employee notification of monitoring data, the availability of hearing protective devices and a recordkeeping system.

Monitoring to assess an employee's noise exposure can be conducted using sound level meters or personal noise dosimeters. Regardless of the type of monitoring instrument used, all continuous, intermittent and impulsive sound levels from 80 decibels to 130 decibels must be integrated in the noise measurements (OSHA Standard - 29 CFR 1910.95). The regulation states that hearing protection must be provided when employees are exposed to noise levels at or above $85 \mathrm{dBA}$ TWA. However, hearing protection is required to be worn under the following conditions: new employees working in a noise environment of $85 \mathrm{dBA}$ 
TWA who do not have a hearing baseline; all employees who are exposed at or above $90 \mathrm{dBA}$ TWA; or following a standard threshold shift.

In the early 1970 's NIOSH was created to evaluate and recommend safe exposure levels for use by OSHA in determining the regulatory OEL. NIOSH recommended a noise exposure level of 85 dBA TWA as documented in the 1972 "Criteria for a Recommended Standard" (NIOSH 1998). In the mid 1990's NIOSH reevaluated their initial exposure recommendation and determined $85 \mathrm{dBA}$ TWA was preventative according to the scientific literature used at that time (NIOSH 1998). OSHA has continued to use 90 dBA TWA with a 5 decibel exchange rate for evaluating noise exposure. The exchange rate means that for each 5 $\mathrm{dB}$ increase in the noise level, the exposure time is reduced by half. For example, an unprotected person may work in a noise environment at $85 \mathrm{~dB}$ for up to 16 hours and at $90 \mathrm{~dB}$ for 8 hours. The NIOSH recommended exposure limit and the ACGIH threshold limit value use an exposure criterion of $85 \mathrm{dBA}$ as an 8-hour TWA with a 3 decibel time/intensity trading relationship (NIOSH 1998). The ACGIH TLV for noise was selected to protect the median of the population against NIHL exceeding $2 \mathrm{~dB}$ in the lower hearing frequencies (ACGIH 2001). Using the $3 \mathrm{~dB}$ exchange rate, an employee can be exposed to $85 \mathrm{dBA}$ for up to 8 hours without the use of hearing protection but for no more than 4 hours at $88 \mathrm{dBA}$ as noted in Table I. 
Table l. Noise Exposure Duration

\begin{tabular}{cccc}
\hline & \multicolumn{3}{c}{ Sound Level dB(A) } \\
$\begin{array}{c}\text { Exposure Duration } \\
\text { (hrs/day) }\end{array}$ & ACGIH & NIOSH & OSHA \\
\hline 16 & 82 & 82 & 85 \\
8 & 85 & 85 & 90 \\
4 & 88 & 88 & 95 \\
2 & 91 & 91 & 100 \\
1 & 94 & 94 & 105 \\
0.5 & 97 & 97 & 110 \\
0.25 & 100 & 100 & 115 \\
0.125 & 103 & 103 & \\
\hline
\end{tabular}

Note: Sources are ACGIH, 2012, NIOSH, 1998 and

Occupational Safety and Health Administration, 2008

In the mid $1960 \mathrm{~s}$, industrial hygiene professionals and physicians practicing in industrial medicine and otolaryngology formed a committee to study noise exposure and hearing loss. A set of guidelines was published through the American Industrial Hygiene Association for noise exposure evaluations to minimize the development or aggravation of permanent hearing impairment in industry. The committee recognized that approximately $20 \%$ of the general population between the ages of 50 and 59 experienced hearing loss without exposure to industrial noise (Plog et al. 1996). However, the incidence of hearing loss was even greater for persons between the ages of 50 and 59 who were exposed to industrial noise over a working lifetime (AIHA 1967). For example, exposure to continuous noise at 90 dBA will result in hearing loss to 27 percent of the exposed group (Plog et al. 1996). The committee also reported that noise-induced hearing loss increased with both the intensity of the noise and the duration of exposure (AIHA 1967).

The published guidelines suggested the use of a sound level meter or a personal noise dosimeter set to the A-weighting scale for monitoring both personal and source noise levels. This filter is weighted to approximate the sensory response of the human ear to sound 
frequencies near the threshold of hearing. This means the low frequency components are diminished and frequencies above $500 \mathrm{~Hz}$ will dominate (Berger 2003). Decibels are a dimensionless quantity that represents the logarithmic relationship of the measured sound pressure level to an arbitrary reference sound pressure of 20 micropascals. This ratio represents the normal threshold of human hearing at a frequency of $1000 \mathrm{~Hz}$ (NIOSH 2008). Monitoring data using the A-weighting and decibels is reported as dBA. Because the decibel is logarithmic, an increase of $3 \mathrm{dBA}$ represents a doubling of the energy whereas an increase of $10 \mathrm{dBA}$ represents a tenfold increase in the energy (Berger 2003).

Placement of the noise dosimeter microphone on the body is an important consideration for accurate measurements. The body position to the noise source and the location of the microphone on the person can affect the response of the microphone (Muldoon 1973). Barrier effects from the body during noise monitoring can be reduced through correct microphone placement on the body. The optimum location is on top of the shoulder between the shoulder edge and neck with the microphone pointing upwards (Byrne et al. 2008). This placement strategy is also the recommended position by equipment manufacturers and has become an industry wide practice amongst industrial hygiene professionals (Berger 2003).

\section{Noise Exposure Assessments}

Noise exposure is measured to assess the potential for hearing damage using either a sound level meter (SLM) or a personal noise dosimeter (Berger et al. 2003). A sound level meter is used to measure noise levels at the source that may be a single piece of equipment or it may involve a combination of equipment or systems (Plog et al. 1996). A noise dosimeter is an instrument worn on the body with a microphone placed in the hearing zone to measure 
sound levels in the immediate vicinity of the person's ear. For regulatory compliance, noise dosimeters must comply with the American National Standards Institute (ANSI) specification S1.25-1991(Kardous et al. 2004). The typical ANSI approved noise dosimeter used by industry is a type II which has an accuracy of $\pm 2 \mathrm{~dB}$. A noise dosimeter integrates noise levels above the threshold level and provides a TWA noise exposure and a dose. During a 24hour period, a worker is allowed up to $100 \%$ of his daily noise dose (NIOSH 1996). A 100\% dose is equivalent to an 8 hour TWA of $85 \mathrm{dBA}$ using ACGIH criteria or $90 \mathrm{dBA}$ following the OSHA regulation. The TWA can be calculated when monitoring data is provided as dose using one of the following equations:

The first equation is used when the data was obtained with OSHA criteria and the second equation is used for data obtained with ACGIH or NIOSH sampling criteria.

Equation 1: $T W A=16.61 \times \log ($ dose $/ 100)+90$

Equation 2: $T W A=9.97 \times \log ($ dose $/ 100)+85$

A SLM can be used to evaluate an individual's noise dose when the sound level is constant over the entire work shift or when the exposure time is known for different noise levels as given by the following equation:

$$
\% \text { Dose }=100\left[\left(C_{1} / T_{1}\right)+\left(C_{2} / T_{2}\right)+\left(C_{n} / T_{n}\right)\right]
$$

Where $C_{n}$ is the amount of time an employee was exposed to noise at a specific level, and $\mathrm{T}_{\mathrm{n}}$ indicates the reference duration for that level as noted in Table 1. 
Noise dosimeters, however, should be used in work areas where an individual's activities are suspected to have a greater impact on the sound levels than other noise sources in the work area (Hansen et al. 1989). A workplace such as a maintenance shop would have potential for high noise levels periodically throughout the work day. Noise levels would also be impacted by the number of machines operating and their proximity to one another. For example, the projected employee noise exposure was evaluated using a SLM and a noise dosimeter. Using a SLM, noise levels were measured for each piece of equipment operated in a machine shop. The employees' noise dose was calculated by estimating the amount of time the equipment was used. Employees working in the shop wore personal noise dosimeters for the duration of their work shift. The noise survey data obtained from the two instruments suggested the sound level meter underestimated the true noise exposure due in part to the variability of the work tasks. Other factors impacting the SLM data included the time estimation for equipment usage and other noise generating activities that were not sampled during the walk-through survey (Hansen et al. 1989). A walk-through survey using a sound level meter may miss intermittent work tasks or work areas where employees could be subjected to high short-duration noise levels resulting in overexposure.

NIOSH is a research institute, not a regulatory agency, and will provide no-cost workplace exposure evaluations upon the request of an employer or their employees. NIOSH will determine existing health hazards and provide suggestions to mitigate the hazards. A review of several NIOSH health hazard evaluation reports suggest that vehicle mechanics can be regularly exposed to noise levels above the ACGIH 8-hour TWA of $85 \mathrm{dBA}$ and are periodically exposed above the OSHA PEL of $90 \mathrm{dBA}$ depending on the work tasks. An 
evaluation of a fire department was conducted to evaluate the noise exposure for employees using pneumatic tools to remove and replace truck tires. This evaluation included personal noise dosimetry and equipment sound level measurements. Although the work tasks involving tightening or loosening automotive lugnuts using a $12.7 \mathrm{~mm}$ impactor gun was of short duration, the noise levels ranged between $111 \mathrm{dBA}-120 \mathrm{dBA}$, resulting in an 8-hour TWA greater than $85 \mathrm{dBA}$ (NIOSH 2008).

The type of activities involving service work on vehicles varies on a daily basis. Employee noise exposure potential will also vary by their work tasks. Auto body work and tire repair activities can generate high impact noise over a short duration potentially overexposing the employee (NIOSH 2004, NIOSH 1996). Tasks involving striking tools against metal surfaces generate high impact, short term noise. The noise dose measured for an auto body worker was $185 \%$ and the tire repair worker exposure resulted in a dose of $253 \%$. The potential for high noise exposure is expected for work activities involving the use of pneumatic tools. In Spencer (2010), the 8-hour TWA was $91 \mathrm{dBA}$ for a field service mechanic working around heavy equipment engines. The mechanic's work tasks involved driving a service vehicle to various work locations to change vehicle fluids and lubricate equipment. The time at each service stop averaged approximately 12 minutes and the work involved the use of hand tools or small power tools.

Equipment manufacturers often provide the expected noise level during tool operation for their products. The information can be found in the equipment manual or on a label placed on the equipment. 
The Centers for Disease Control Power Tools Database managed by NIOSH also provides noise levels for several types of equipment listed by manufacturer. The noise levels obtained from the database for pneumatic tools while under load range from $95-107 \mathrm{~dB}$ for hand-held grinding wheels, $74-93 \mathrm{~dB}$ for orbital sanders and $101-111$ for impact wrenches. (CDC 2010). The database, however, is limited in the amount of information provided. The noise levels observed for air compressors during operation ranged from $91-97 \mathrm{~dB}$ at a distance $91 \mathrm{~cm}$ from the equipment (Forouharmajd 2012). 


\section{MATERIALS AND METHODS}

\section{Overview}

The fleet service group consists of three general maintenance and repair facilities with a separate facility for auto body work that includes a paint booth and a work area for sanding on vehicles and equipment. These facilities reside within the Department of Energy's Hanford site in Benton County located in southeastern Washington State. The staff includes 16 general light duty mechanics, 4 light duty tire and lubrication mechanics, 2 auto body service technicians, 2 mechanics supporting Hanford site construction services, 17 general heavy equipment mechanics, and 4 heavy equipment oilers. The mechanics only work a day shift and are scheduled for 10 hours per day, 4 days per week with the employees shifts split between a Monday through Thursday and a Tuesday through Friday work schedule.

The job titles for the mechanics differentiate between heavy and light equipment mechanic, a classification distinction defining the types of vehicles and equipment they are responsible for servicing. Light equipment general mechanics service and repair a variety of vehicles including large trucks, pickups, passenger cars, trailers, off-road vehicles and utility vehicles. Their work scope also includes the tire and lubrication mechanics and the auto body service technicians. Heavy equipment general mechanics and heavy equipment oilers repair and maintain forklifts, backhoes, excavators, cranes, generators, air compressors, pumps, farm machinery, lawn mowers and construction equipment. 


\section{Facility and Work Process Descriptions}

Building number 1 is a general maintenance facility used by the heavy equipment and light equipment mechanics. This facility consists of three steel frame buildings designed and built for vehicle and equipment maintenance. The main section, identified as 1 was built in 1984 and has approximately $7,110 \mathrm{ft}^{2}$ of work space with a ceiling height of $31.5 \mathrm{ft}$. Building 1 has five vehicle work bays with overhead doors. Four of the service bays are located on the southern wall. The oil change and lube bay is located on the east wall and has a service pit that runs east/west. Light equipment mechanics can work in any of the four service bays in addition to the area adjacent to and west of the lube bay.

In 1991 an additional steel building was built onto the north side of 1 and was designated as $1 \mathrm{~A}$. The structure consists of $4,443 \mathrm{ft}^{2}$ with a 32.7 foot ceiling height. This building section is used exclusively by heavy equipment mechanics and access into the main building is through a man door. There are two rollup doors located on the east and west ends.

In 1995, another building section, identified as 1B, was added on to the southwest side of 1 also for use by heavy equipment mechanics. This building section added $4,494 \mathrm{ft}^{2}$ of work space and has a ceiling height of 32.9 feet. The design of this section allowed for an open work space on the northwest end of 1 and northwest corner of $1 \mathrm{~B}$. This part of the facility has a long work bay for large equipment running north/south with the rollup door along the south wall and a smaller bay on the north end with the rollup door on the west wall. 
Heating and cooling for the facility is provided by a forced air system. Each building section has its own cooling system. During cold weather, the rollup doors are kept closed except when vehicles are being moved in or out of the shop whereas during warmer weather the doors typically remain open. The bays within the 1 complex have an overhead vehicle exhaust system that is accessible in each of the work bays. Portable local exhaust ventilation systems are used throughout the shops during welding, grinding and torch cutting activities.

Facility 2

The 2 facility was originally constructed as a storage building in 1985 and was converted to a mechanic's garage in the late 1990 's with $6000 \mathrm{ft}^{2}$ of work space and a ceiling height of 22.5 feet. This building has rollup doors on the north and south end in addition to 7 service bays with rollup doors on the east and west sides of the building. Each service bays has a vehicle exhaust system that vents directly outdoors. Welding and grinding activities are done throughout the shop and a portable local exhaust ventilation system is used.

The building is heated and cooled with an overhead forced air system. During cold weather, the garage doors are kept closed except when vehicles are being moved in or out of the shop and during warmer weather the garage doors are typically left open.

Facility 3

The vehicle maintenance shop located in the 400 area is an open facility with $8092 \mathrm{ft}^{2}$ of work space and a ceiling height of 20 feet. Parts storage, a computer workstation, and an eating area are located within this facility. 
There are two rollup doors located on the north and two on the south ends of the building. Facility 3 facility houses four light duty mechanics, one tire and lube mechanic and one heavy duty mechanic. Typically only three of the four available work bays are used by the mechanics. Vehicles brought in for lube and tire services are driven into the building from the north end to access the lube and tire station located at the south end of the building. Oil change and lube service is provided with use of one of the two vehicle lifts that are mounted to the concrete floor. The other vehicle lift is located near the center of the building. The service bay located on the southeast end is used by the heavy duty mechanic. The building is heated with overhead electrical heaters and cooling is provided with large fans and a portable swamp cooler. During cold weather, the garage doors are kept closed except when vehicles are being moved in or out of the shop and during warmer weather the garage doors are frequently left open. This building does not have a vehicle exhaust system but relies on natural ventilation alone.

Facility 4

This building is used for auto body work and is smaller with $4080 \mathrm{ft}^{2}$ of work space and a ceiling height of 14.8 feet. The facility was designed with separate work areas for sanding and painting. Spray finishing occurs in a paint booth located near the center of the building. Access is through a rollup door on the east end of the facility. Body work activities occur in a room approximately $1500 \mathrm{ft}^{2}$ located on the west end of the building. Sanding activities are typically conducted with a ventilated orbital sander and respiratory protection. Heating and cooling is provided through a forced air system. This building does not have a vehicle exhaust system. 


\section{Similar Exposure Groups}

The similar exposure groups were determined through a process of direct observation of the work tasks, discussions with the mechanics about their job tasks, the chemical products they use, and the tools and equipment they use. The job tasks for the different job titles were directly observed to evaluate the frequency and duration of the chemical products used and to determine the processes that had a potential for noise exposure. In addition, the work areas for the three general mechanic shops were evaluated for size, workflow patterns, and ventilation systems.

A single chemical inventory is maintained for all the shops and chemical products are ordered from a pre-approved list. Material safety data sheets for all chemical products on the inventory were reviewed to determine if any of the products listed benzene as a constituent and to identify which products contained petroleum-derived solvents that had a potential to contain trace amounts of benzene. Both light equipment mechanics and heavy equipment mechanics used many of the same products with the commonly used products limited to aerosol lubricants and solvents, a solvent based parts washer, and spray paints (Table II). An exposure profile is located in Appendix A that identifies the assigned exposure rating for each of the similar exposure groups.

The exposure rating is an estimate of the exposure relative to the OEL as noted in Table II. In the absence of sample data, an initial exposure rating is typically a 3 or 4 because of the uncertainty in the exposure level over time. The use of personal protective equipment 
is not considered as an exposure reduction method during the initial exposure judgment resulting in a higher rating number.

Table II. SEG Summary

\begin{tabular}{|c|c|c|c|c|c|}
\hline \multirow[t]{2}{*}{ Task / Product Use } & \multirow[t]{2}{*}{$(\mathrm{N})$} & \multicolumn{3}{|c|}{ Exposure Rating } & \multirow{2}{*}{$\begin{array}{l}\text { Pre Sampling } \\
\text { Judgment }\end{array}$} \\
\hline & & Benzene & Lead & Noise & \\
\hline $\begin{array}{l}\text { Use gasoline, aerosol degreaser } \\
\text { solvents, spray paints, lubricants, } \\
\text { vehicle exhaust, parts washer }\end{array}$ & 45 & 3 & & & $\begin{array}{c}\text { Uncertain, } \\
\text { insufficient data }\end{array}$ \\
\hline $\begin{array}{l}\text { Welding, grinding, cleaning parts } \\
\text { with bead blaster, sanding paint } \\
\text { and body filler }\end{array}$ & 35 & & 3 & & $\begin{array}{l}\text { Uncertain, } \\
\text { insufficient data }\end{array}$ \\
\hline $\begin{array}{l}\text { Pneumatic air tools, engine } \\
\text { noise, welding, grinding, air } \\
\text { compressor, impact sources, } \\
\text { heavy construction equipment, } \\
\text { generator }\end{array}$ & 45 & & & 4 & $\begin{array}{l}\text { Exposure not } \\
\text { acceptable }\end{array}$ \\
\hline
\end{tabular}

Table III. Exposure Rating Classification

\begin{tabular}{cl}
\hline & \multicolumn{1}{c}{$\begin{array}{c}\text { Exposure } \\
\text { Estimate }\end{array}$} \\
\hline Rating & $>$ OEL \\
3 & $50 \%-100 \%$ OEL \\
2 & $10 \%-50 \%$ OEL \\
1 & $<10 \%$ OEL \\
\hline
\end{tabular}

(Ignacio et at., 2006) 


\section{Benzene Sampling and Analysis}

Airborne benzene exposure sampling was conducted on both light equipment and heavy equipment mechanics and occurred in the three general mechanic shops. There were a total of eleven sampling events with the first nine sampling events occurring between June 18, 2012 and June 28, 2012. The air samples collected during this time frame were used to evaluate the 8-hour TWA exposures for randomly selected employees. Two sampling events occurred in August for specific work tasks with the sample time equal to the amount of time required to complete the task. These task-based sample events were for scheduled work that involved use of petroleum-derived solvents potentially containing benzene.

Benzene was sampled with $3 \mathrm{M}^{\mathrm{TM}} 3520$ Organic Vapor diffusion badges. Each badge was individually packaged in a small sealed can. The can was opened immediately prior to sampling and the badge was removed from the can and clipped onto the employee's collar within their breathing zone for the majority of the employee's work day. One field blank sample was also prepared at the beginning of each sampling period following the instructions

provided by $3 \mathrm{M}^{\mathrm{TM}}$ for preparation and use of the 3520 diffusion badges. Relative humidity and the ambient outdoor temperature were obtained from the Hanford Meteorological Station and recorded for each sampling day between the hours of 11:00 AM and 12:00 PM. Near the end of the workday, the badge was removed from the employee's collar and capped according to the manufacturer instructions and placed into the can which was closed with the plastic lid. The collected badges and the field blank were then placed into a Ziplock bag which was sealed and refrigerated overnight until they could be taken to the laboratory for analysis. 
All samples were analyzed at the Waste Sampling and Characterization Facility (WSCF) located on the Hanford site. This is a full service laboratory that is accredited by the Washington State Department of Ecology and the American Industrial Hygiene Association. The nine personal air samples obtained between June 18, 2012 and June 28, 2012 were fullshift samples with sample times ranging from 442 minutes to 504 minutes. The task-based air samples obtained in August had sample times ranging from 31 minutes to 90 minutes. During the 31 minute task-specific sampling event, in addition to collecting a personal breathing zone sample, a diffusion badge was also placed inside the work area where the employee was using a solvent to clean and degrease metal surfaces.

For each day of sampling, the mechanics were asked to track their chemical usage by product name and approximate amount used (Appendix B). In addition to submitting the samples to the laboratory for benzene concentration, analysis was requested for other volatile organic compounds suspected to be in the work environment. These compounds were identified as product constituents on the MSDS or in the case of n-Octane, a component of vehicle exhaust. The other analytes included acetone, ethyl ether, toluene, xylene, ethylbenzene, VM\&P naphtha, methyl ethyl ketone, and trichloroethylene. The VOC laboratory analysis printouts were requested to identify if any compounds other than the requested analytes were present in the samples. Chemical products used by the mechanics included carburetor and choke cleaner, starting fluid, spray paints and some common aerosol lubricants. 


\section{Analytical Procedure}

Laboratory analysis was based on an analytical procedure that follows the $3 \mathrm{M}^{\mathrm{TM}}$ Technical Data Bulletin Organic Vapor Monitor Sampling and Analysis Guide (3M Technical Data Bulletin 1028). Carbon disulfide is used to desorb the contaminants from the sampling badges. The resulting desorption solution is then analyzed by gas chromatograph (GC) equipped with a flame ionization detector (GC-FID). An autosampler injection system is used to inject the samples and standards. Tentative sample component identifications are based upon retention time matches / comparisons between sample peaks and standard / reference peaks. Quantization is based on sample peak areas or heights compared to standard areas or heights. Response factors and calibration curves are determined and created by using statistically determined number of concentrations of prepared standards.

Four detection limits were identified on the laboratory reports for the requested analytes. The detection limits for total xylenes were $0.004 \mathrm{mg}$ and $0.008 \mathrm{mg}$ which did not appear to be related to the air volume. The detection limit was $0.02 \mathrm{mg}$ for naphtha and 0.05 $\mathrm{mg}$ for trichloroethylene. Other VOCs analyzed had a detection limit of $0.004 \mathrm{mg}$.

Sample results for benzene and the field blanks were all below the detection limit. Concentrations were reported above the reporting detection limit for acetone, ethyl ether, toluene and xylene in seven of the samples (Appendix B). The 8-hr TWA was calculated for sample results that were above the detection limit. The TWA concentration is calculated with the following two equations: 


\section{Equation 1:}

$$
B=(1000 \times 24.45) /(\text { sampling rate } \times \text { molecular weight })
$$

Sampling rate is provided in the 3M Bulletin 1028 .

Equation 2:

$C($ ppm $)=($ sample concentration $\mu g) \times B /(r \times t)$ minutes $)$

Where: $\quad r=$ recovery coefficient, given by $3 \mathrm{M}$ Bulletin 1028 , and $\mathrm{t}=$ sample time in minutes

The $3 \mathrm{M}^{\mathrm{TM}} 3520$ badges are designed with a front and back section. Each section is analyzed separately to check for breakthrough. Before calculating the total sample concentration, the sample must be verified as valid. The sample is valid if the ratio of the contaminant weight on back section to the contaminant weight of the front section is $<0.5$. The analytical laboratory report provided one contaminant concentration for each sample.

\section{Lead Sampling and Analysis}

Lead was sampled during all work activities having the potential for lead dust exposure. Six sampling events occurred between March and August 2012. The task-specific sampling for airborne lead dust was performed using SKC $37 \mathrm{~mm} 3$ piece pre-banded preloaded cassettes with a $0.8 \mu \mathrm{m}$ cellulose ester membrane connected to a personal sampling pump with flexible tubing. Before and after each sampling event the sampling pumps were calibrated with an in line representative cassette using a Bios DryCal DC-Lite 5K primary calibration instrument. Pre and post calibration values were within $5 \%$ of one another for all cases. For the pre-sampling calibration, the sampling pumps were run for 10 minutes before being calibrated. Pump flow rates ranged between 1.99 liters per minute to 3.0 liters per 
minute, and the run times for personal samples were determined by the length of the tasks, which ranged from 43 minutes up to 259 minutes.

Personal sampling was conducted only for the duration when the employee was performing the work task involving potential lead dust and did not include breaks or other work activities. For each work task sampled, the sampling cassette was connected to the employee's collar within their breathing zone and the pump was attached to the employee's belt. Immediately before the employee began performing their work task, the cassette end plug was removed and the pump was switched on. At the end of each sampling event, the cassettes were sealed and placed into a Ziplock bag that was closed and transported to the WSCF Laboratory for analysis following the NIOSH 7300 method (NIOSH 2003). One field blank was prepared for each day of sampling and submitted for analysis with each sample set.

Five of the work activities were conducted indoors and one task was done outside. Sampling on indoor tasks included a breathing zone and an area sample. Two tasks identified by sample ID 60201 and 60206 were performed by the same employee on two separate occasions. For both activities, two breathing zone samples were obtained, and the results of each day's sampling were combined for the 8-hour TWA. Sample ID 60236 involved two employees using the ventilated orbital sander to remove paint and body filler compound. One breathing zone sample was collected on each employee in addition to an area sample. The sample ID is a specific number assigned to the sample set and is followed by a suffix of P1, $\mathrm{P} 2, \mathrm{~A} 1$ or A2. The suffix refers to type of sample such as breathing zone (P1) or area (A1). 
Although lead was the analyte of concern, five of the sample sets were submitted for a metal scan analysis and one sample set was analyzed for lead and aluminum. A metal scan analysis allows for identification of other metals that could be present in the paint. Analysis for only lead and aluminum was requested because the vehicle had sections repaired and painted at the body shop previously. The MSDS for the paint used on the former repair listed aluminum as a constituent and no information was available for the original equipment manufacturing (OEM) paint.

The 8-hr TWA was calculated for all metal results above the detection limit and compared to the ACGIH TLV to determine the acceptability of the exposures. Results that are below $10 \%$ of the OEL are typically considered acceptable. The 8-hour TWA concentration is calculated with the following equation:

$$
\text { 8-hour } T W A=\left(C_{1} * T_{1}\right)+\left(C_{n} * T_{n}\right) / 480 \text { minutes }
$$

The reporting detection for lead is $0.001 \mathrm{mg}$ but is different for some of the other metals (Appendix C). The mean, standard deviation and upper 95\% confidence limit was calculated for metals reported above the detection limit. Although the samples were taskbased, an 8-hour TWA was also calculated for each sample for comparison with the OEL.

\section{Noise Sampling and Analysis}

Noise dosimetry monitoring was conducted on a random basis. For each day of monitoring, up to four noise dosimeters were prepared and the mechanics present at the shop between 7:00 - 8:00 AM were asked to wear a noise dosimeter. On two separate occasions, a 
mechanic requested to be excluded from the monitoring because they would not be working their full shift and planned to leave before their lunch time.

Personal noise monitoring was conducted using Quest Technologies Quest Edge eg5 dosimeters for the majority of the employee's work shift with times ranging from 418 minutes to 508 minutes. The mechanics randomly selected for monitoring were asked to participate in the sampling program at the beginning of their work shift. Employees work 10-hours per day which includes a meeting at the beginning of their work shift and a period at the end of the shift to allow for cleanup of the work area and to change out of their work coveralls. Sampling was initiated after their morning meeting when the mechanics started work in the shops, and continued through their two 15 minute break times and half-hour lunch period. Monitoring was stopped when workers began their end-of-the-day cleanup activities. The mechanics who were wearing the noise dosimeters were asked to write down what tools and equipment they used and the approximate times the equipment was being used. The dosimeters were set to the A-weighted network with slow meter response and used with two settings, one of which was the ACGIH TLV with the threshold limit set at $80 \mathrm{~dB}$, an exchange rate of $3 \mathrm{~dB}$ and the 8 -hour criterion level at $85 \mathrm{~dB}$. A second setting was used to determine the true average exposure level known as LEQ. The LEQ setting also uses a $3 \mathrm{~dB}$ exchange rate and an $8-\mathrm{hr}$ criterion level of $85 \mathrm{~dB}$ but does not have a threshold limit. When a threshold limit is not used, all noise levels above and below the limit are integrated in to the TWA exposure. 
Per the manufacturer's instructions for placement or removal of the dosimeter from the individual, the noise dosimeter was placed into "pause" mode to avoid bumping of the microphone during handling. The calibration for each instrument was checked before use and the calibration was verified after being removed from the employee using a Quest Technologies QC-10 calibrator. The calibrator used was set to $114 \mathrm{~dB}$, and if the dosimeter readout did not indicate $114 \mathrm{~dB}$ during the initial morning calibration check, the microphone was adjusted to the correct noise level to reduce error in the sample data. The dosimeter was positioned onto the top center portion of the employee's shoulder with the microphone facing upward. Noise level data was downloaded at the end of each sampling session and analyzed using QuestSuite Professional II software.

Noise sampling data is provided in Appendix D. Sample data was plotted to evaluate for normality and a goodness-of-fit was checked using the Shapiro-Wilkes test for normality. The arithmetic mean, geometric mean, standard deviations and the upper $95 \%$ confidence limit were calculated to evaluate potential noise exposure differences between the light equipment and heavy equipment mechanics. 


\section{RESULTS}

\section{Similar Exposure Group (SEG)}

Fleet services group has two mechanic job distinctions based on the types of equipment that are serviced. The light equipment service group includes 16 general mechanics, 4 tire and lubrication mechanics, two construction mechanics and 2 auto body service technicians. Heavy equipment is made up of 17 general mechanics and 4 heavy equipment oiler mechanics. Auto body work is provided in a standalone facility specifically designed for preparation and painting activities. The other mechanics work in one of three maintenance facilities that range in size from $4,443 \mathrm{ft}^{2}$ up to $8,092 \mathrm{ft}^{2}$. These buildings have high ceilings and rollup doors located on opposite walls (Table IV).

Table IV. Facility Information

\begin{tabular}{ccccccc}
\hline $\begin{array}{c}\text { Ceiling } \\
\text { Building } \\
\text { No. }\end{array}$ & $\begin{array}{c}\text { Size } \\
\left(\mathrm{ft}^{2}\right)\end{array}$ & $\begin{array}{c}\text { Overhead } \\
\text { Vehight } \\
(\mathrm{ft})\end{array}$ & $\begin{array}{c}\text { Exhaust } \\
\text { System }\end{array}$ & Heating System & $\begin{array}{c}\text { Type of } \\
\text { Work }\end{array}$ & $\begin{array}{c}\text { Rollup } \\
\text { Doors }\end{array}$ \\
\hline $1^{\mathrm{B}}$ & $7,110^{\mathrm{C}}$ & 31.5 & Yes & Forced Air & LE & 5 \\
$1 \mathrm{~A}$ & 4,443 & 32 & Yes & Forced Air & HE & 2 \\
$1 \mathrm{~B}$ & 4,494 & 32.7 & Yes & Forced Air & HE & 2 \\
2 & 6,000 & 22.5 & Yes & Forced Air & LE & 9 \\
3 & 8,092 & 20 & No & $\begin{array}{c}\text { Electric Heat } / \\
\text { Swamp Cooler }\end{array}$ & LE / HE & 4 \\
4 & 4,080 & 14.8 & No & Forced Air & Auto & Body \\
\hline
\end{tabular}

\footnotetext{
${ }^{\mathrm{A}} \mathrm{LE}$ refers to light equipment mechanics. HE refers to heavy equipment mechanics.

${ }^{\mathrm{B}} 1 \mathrm{~A}$ and $1 \mathrm{~B}$ are additional workspaces attached to building 1 .

${ }^{\mathrm{C}}$ Square footage provided is for building lonly.
} 
Chemicals identified as having been used on the days of sampling include engine oil, carburetor and choke cleaner, starting fluid, WD 40 aerosol lubricant, spray paints, Kroil aerosol lubricant and a cleaning solvent called DX320. The amount of product used was described as one-fourth of a container up to two full cans on one project for the aerosol cans. The product selection and amount used is typically determined by the work tasks. Aerosol degreasing products and aerosol lubricants are products that are typically used daily.

A review of the occupational health risks for the mechanics assigned to the fleet services group identified a similar exposure potential to noise and chemicals such as benzene for all of the mechanics. However, potential exposure to lead dust would occur during mechanical paint removal using orbital sanding equipment or a hand-held grinding wheel. This work scope is limited to the heavy and light equipment general mechanics and the auto body mechanics (Table V). 
Table V. Similar Exposure Group Summary

\begin{tabular}{|c|c|c|c|c|}
\hline Hazard & Classification & Job Title & $(\mathrm{N})$ & Product / Task \\
\hline \multirow[t]{10}{*}{ Benzene } & \multirow[t]{4}{*}{ Light Equipment } & General Mechanics & 16 & Aerosol Paints \\
\hline & & Tire \& Lubrication & 4 & $\begin{array}{l}\text { Aerosol Degreasing } \\
\text { Solvents }\end{array}$ \\
\hline & & Construction & 2 & Aerosol Lubricants \\
\hline & & Auto Body & 2 & Gasoline \\
\hline & \multirow[t]{6}{*}{ Heavy Equipment } & General & 17 & Aerosol Paints \\
\hline & & Oilers & 4 & Aerosol Degreasing \\
\hline & & & & Solvents \\
\hline & & & & Aerosol Lubricants \\
\hline & & & & Gasoline \\
\hline & & & & Parts Washer \\
\hline \multirow[t]{4}{*}{ Lead } & \multirow{2}{*}{ Light Equipment } & General Mechanics & 16 & Grinding / Welding \\
\hline & & Auto Body & 2 & $\begin{array}{l}\text { Sanding Paint / Body } \\
\text { Filler }\end{array}$ \\
\hline & \multirow[t]{2}{*}{ Heavy Equipment } & General Mechanics & 17 & Grinding / Welding \\
\hline & & & & Bead Blaster Equipment \\
\hline \multirow[t]{8}{*}{ Noise } & \multirow[t]{4}{*}{ Light Equipment } & General Mechanics & 16 & Pneumatic Tools \\
\hline & & Lube \& Tire & 4 & Air Compressors \\
\hline & & Auto Body & 2 & Engine Noise \\
\hline & & Construction & 2 & \\
\hline & \multirow[t]{4}{*}{ Heavy Equipment } & General & 17 & Pneumatic Tools \\
\hline & & Oilers & 4 & Air Compressors \\
\hline & & & & Engine Noise \\
\hline & & & & Generators \\
\hline
\end{tabular}

\section{Benzene}

Thirteen air samples were collected of which twelve were breathing zone samples and one was an area sample. Breathing zone samples were obtained on 10 employees and 2 employees were sampled twice. There were 11 work activities sampled which included routine tasks such as replacing tires and changing engine fluids. In general, the work 
activities for most of the mechanics varied on a daily basis. Nine 8-hour TWA samples and three short duration breathing zone samples were collected. The TWA sample durations ranged from 442 minutes to 504 minutes. Table VI shows the VOC monitoring results for the 8-hour TWA samples. Low airborne concentrations of acetone, toluene and ethyl ether were found in levels above the detection limit but less than $10 \%$ of the OEL. Benzene, n-Octane, trichloroethylene, xylene and field blanks were all below the detection limit. 
TABLE VI. VOC Monitoring Results, 8-hour TWA

\begin{tabular}{|c|c|c|c|c|c|c|c|}
\hline Task & Benzene & Acetone & $\begin{array}{l}\text { Ethyl } \\
\text { Ether }\end{array}$ & Octane & Toluene & TCE & Xylene \\
\hline $\begin{array}{l}\text { Repairing forklift } \\
\text { hydraulic system } \\
(\mathrm{n}=1)\end{array}$ & $<0.08$ & 3.37 & $<0.08$ & $<0.06$ & 0.17 & N/A & $<0.07$ \\
\hline $\begin{array}{l}\text { Replace fuel pump, } \\
\text { mass air flow sensor } \\
(\mathrm{n}=1)\end{array}$ & $<0.08$ & $<0.1$ & $<0.08$ & $<0.06$ & $<0.07$ & N/A & $<0.07$ \\
\hline $\begin{array}{l}\text { Repair boom and } \\
\text { auger on lineman truck } \\
(\mathrm{n}=1)\end{array}$ & $<0.08$ & N/A & N/A & $<0.06$ & $<0.07$ & N/A & $<0.07$ \\
\hline $\begin{array}{l}\text { Install toolboxes and } \\
\text { liftgate latches }(n=1)\end{array}$ & $<0.08$ & N/A & N/A & $<0.06$ & $<0.07$ & N/A & $<0.07$ \\
\hline $\begin{array}{l}\text { Install boom onto } \\
\text { lineman truck }(\mathrm{n}=1)\end{array}$ & $<0.08$ & 1.47 & 1.3 & $<0.06$ & 0.08 & $<0.05$ & N/A \\
\hline $\begin{array}{l}\text { Repair/replace vehicle } \\
\text { tires, change engine } \\
\text { fluids }(\mathrm{n}=1)\end{array}$ & $<0.08$ & $<0.01$ & $<0.08$ & $<0.06$ & $<0.07$ & $<0.05$ & N/A \\
\hline $\begin{array}{l}\text { Paint wheels, } \\
\text { repair/replace vehicle } \\
\text { tires, change engine } \\
\text { fluids }(n=1)\end{array}$ & $<0.08$ & 1.3 & $\mathrm{~N} / \mathrm{A}$ & $<0.06$ & 0.17 & $<0.05$ & $<0.15$ \\
\hline $\begin{array}{l}\text { Repair electrical } \\
\text { components on flatbed } \\
\text { trailer }(\mathrm{n}=1)\end{array}$ & $<0.08$ & $<0.01$ & $\mathrm{~N} / \mathrm{A}$ & $<0.06$ & $<0.07$ & $<0.05$ & $<0.07$ \\
\hline $\begin{array}{l}\text { Replace tires, change } \\
\text { engine fluids }(n=1)\end{array}$ & $<0.08$ & $<0.01$ & N/A & $<0.06$ & $<0.07$ & $<0.05$ & $<0.07$ \\
\hline
\end{tabular}

Note: All sample concentrations are ppm and represent breathing zone samples. N/A indicates result not applicable, analyte not requested. < indicates sample data below laboratory reporting detection limit.

Two short-duration tasks were sampled and the results are provided in Table VII.

These tasks were considered non-routine work with potential for VOC exposure because of the chemical products and the method of use. For example, one task involved using a degreasing solvent (DX320) applied to a shop rag to clean interior metal surfaces of a vehicle for application of sound dampening material. The total task length was approximately 30 
minutes. The use of a volatile solvent inside a vehicle with limited ventilation presented an exposure potential. A breathing zone and an area sample were collected for the duration of the work activity. Sample concentrations for acetone and toluene were reported as $14.53 \mathrm{ppm}$ and $19.72 \mathrm{ppm}$ for the task duration with an 8-hour TWA of $4.09 \mathrm{ppm}$ for acetone and 6.0 ppm for toluene. The other task involved cleaning structural components on the exterior of a wren-tail trailer using DX320 poured onto a shop rag and then painting the backend with a specially formulated spray paint. The duration of this task was approximately 90 minutes and sample results were all below the detection limit.

Table VII. VOC Monitoring Results, Task-Based

\begin{tabular}{lcccccc}
\multicolumn{1}{c}{ Task } & Benzene & Acetone & MEK & Naphtha & Toluene & Xylene \\
\hline $\begin{array}{l}\text { Clean metal surfaces } \\
\text { with solvent applied to } \\
\text { shop rag (N=1) }\end{array}$ & $<0.08$ & 4.09 & N/A & $<5.16$ & 6 & N/A \\
$\begin{array}{l}\text { Using two cans specially } \\
\text { formulated aerosol spray }\end{array}$ & $<0.08^{\mathrm{A}}$ & $<0.1^{\mathrm{A}}$ & $<0.08^{\mathrm{A}}$ & $<0.06^{\mathrm{A}}$ & $<0.07^{\mathrm{A}}$ & $<0.07^{\mathrm{A}}$ \\
paint (N=2) & N/A & N/A & $<0.06$ & $<0.07$ & $<0.07$ \\
\hline
\end{tabular}

Note: Monitoring data presented as TWA ppm. All sample data represents personal breathing zone samples unless otherwise indicated. < indicates sample data below laboratory reporting detection limit.

${ }^{A}$ Represents area monitoring data. N/A indicates result not applicable, analyte not requested.

The 8-hour TWA samples were collected on a random basis without prior knowledge of the schedule work activities or chemicals expected to be used. VOC monitoring was conducted with passive diffusive badges under normal working conditions with ambient indoor temperatures averaging $57^{\circ} \mathrm{C}$. The ambient outdoor temperature and relative humidity was obtained between the hours of 11:00 - 12:00 each day of monitoring and submitted to the laboratory with the samples. Temperatures ranged from $51-62^{\circ} \mathrm{C}$ and relative humidity ranged from $28 \%-41 \%$ (Appendix B). High ambient temperatures can reduce the ability of 
the sorbent to retain analytes and high humidity can greatly reduce the capturing capacity of the sampling badges. Because air temperature can affect the sample rate, a correction factor of $1 \%$ is used to calculate the TWA concentrations for each $6-7^{\circ} \mathrm{C}$ above or below $35^{\circ} \mathrm{C}$ (Table VIII). The sampling was conducted during the summer months and the rollup doors were open for the majority of the workday. Outdoor temperatures were not high enough to require use of the correction factor. Diffusive badges are recognized by OSHA as having a precision of $\pm 12.6 \%$ when both temperature and pressure are known as compared to the use of sorbent tubes and a sampling pump which has a precision of $\pm 9.94 \%$ (OSHA 2002). The badges were selected for the sampling because of their acceptance by the mechanics as opposed to air sampling pumps that may catch on equipment and are noise.

Table VIII. Sampling Temperature Correction Factor

\begin{tabular}{ccc}
\hline Celsius & Fahrenheit & Correction Factor \\
\hline 44 & 111 & 0.97 \\
37 & 99 & 0.98 \\
31 & 88 & 0.99 \\
25 & 77 & 1.00 \\
19 & 66 & 1.01 \\
13 & 55 & 1.02 \\
7 & 45 & 1.03 \\
2 & 36 & 1.04 \\
-3 & 27 & 1.05 \\
-8 & 18 & 1.06 \\
\hline
\end{tabular}

$\left(3 \mathrm{M}^{\mathrm{TM}}\right.$ Technical Data Bulletin 1028)

\section{Lead}

The SEG for exposure to metal dusts is 38 mechanics and samples were collected on 6 employees. There were 9 breathing zone and 7 area samples obtained for 6 task-based work activities. The work tasks included welding and grinding, paint removal using an orbital 
sander, and filter and media change out on the bead blaster unit. Sample times ranged from 43 minutes -259 minutes, which represented the full exposure time for these activities. All of the sample sets were analyzed for lead in addition to other metals suspected to be present in the coatings. Surface coatings were not tested for the presence of lead before beginning the work activities. Sample results for the field blanks and lead dust were below the detection limit, however the other metals reported above their detection limit are reported in Tables IXXI with additional sampling data located in Appendix C.

All work activities that involved a potential for exposure to metal dusts were sampled. Three of these tasks were during welding and grinding where paint was removed from the surface using grinding wheels before welding could proceed. One of these tasks occurred outdoors and a torch was used to remove paint from around welds because a grinding wheel could not access those areas, sample ID 60201. The same piece of equipment was then brought indoors for additional welding and grinding and local exhaust ventilation was used. Lower airborne metal concentrations were observed for most of the metals on the outdoor activity compared to the indoor task. Metal concentrations observed in the samples were less than $10 \%$ of their OEL. The sample concentration mean ranged from $0.0007 \mathrm{mg}$ for molybdenum to $0.3808 \mathrm{mg}$ for iron (Table IX). 


\section{Table IX. Welding and Grinding Work Activities Summary Results}

\begin{tabular}{lccc}
\hline Metal & $(\mathrm{N})$ & Mean $(\mathrm{mg})$ & $\mathrm{SD}(\mathrm{mg})$ \\
\hline Lead $^{\mathrm{A}}$ & 5 & $<$ LOD & $<$ LOD \\
Aluminum & 5 & 0.0036 & 0.0027 \\
Barium & 5 & 0.0078 & 0.0061 \\
Chromium $^{\mathrm{B}}$ & 4 & 0.0072 & 0.0100 \\
Copper & 5 & 0.0026 & 0.0018 \\
Iron & 5 & 0.3808 & 0.3579 \\
Magnesium & 5 & 0.0025 & 0.0009 \\
Manganese & 5 & 0.0148 & 0.0136 \\
Molybdenum & 5 & 0.0007 & 0.0009 \\
Nickel $^{\mathrm{B}}$ & 4 & 0.0010 & 0.0005 \\
Titanium $^{\mathrm{B}}$ & 4 & 0.0011 & 0.0007 \\
Zinc $^{\mathrm{B}}$ & 4 & 0.0035 & 0.0008 \\
\hline
\end{tabular}

Note: Reported data represent the sample concentrations

${ }^{\mathrm{A}} \mathrm{Lead}$ results were all below the detection limit

${ }^{\text {B }} 5$ samples collected, 1 did not have chromium

Auto body preparation activities often involve the use of an orbital sander. The equipment used in the auto body shop is a Dynabrade ventilated sander to reduce the amount of airborne dust generated. This work activity was sampled two times and breathing zone samples were collected on the two employees in this department. One of the tasks was conducted on a vehicle that had previously been repaired and painted and the paint contents were known, however, the contents of the paint used by the manufacturer was unknown. The samples were submitted for lead and aluminum analysis. Two area samples were also obtained to evaluate the exhaust air from the ventilated sander. A summary of the sample results are located in Table X. Lead and aluminum dust was not detected and the other metals were less than $10 \%$ of the OEL indicating the ventilated sander is an effective engineering control. 
Table X. Summary Data for Auto Body Preparation Activities

Paint Removal with

Orbital Sander

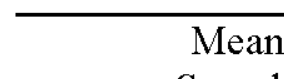

Sample

Conc.

\begin{tabular}{lcclclll} 
Metal & $(\mathrm{N})$ & $(\mathrm{mg})$ & $\mathrm{SD}$ & $(\mathrm{N})$ & $(\mathrm{mg})$ & TWA \\
\hline Lead & 2 & $<$ LOD & N/A & 1 & $<$ LOD & $<0.008$ \\
Aluminum & $\mathrm{N} / \mathrm{A}$ & $\mathrm{N} / \mathrm{A}$ & $\mathrm{N} / \mathrm{A}$ & 1 & $<$ LOD & $<0.016$ \\
Barium & 2 & 0.0024 & 0.0020 & & & \\
Chromium & 1 & 0.0012 & $\mathrm{~N} / \mathrm{A}$ & & & \\
Iron & 2 & 0.0102 & 0.0068 & & & \\
Magnesium & 2 & 0.0503 & 0.0661 & & & \\
Manganese & 1 & 0.0003 & $\mathrm{~N} / \mathrm{A}$ & & & \\
Titanium & 2 & 0.0004 & 0.0002 & & & \\
Zinc & 1 & 0.0020 & N/A & & & \\
\hline
\end{tabular}

Note: All sample data represents personal breathing zone samples. < indicates sample data below laboratory reporting detection limit. N/A indicates result not applicable, analyte not requested.

The final task involved the removal and replacement of the filter system and glass bead media in the bead blaster unit. Exposure to metal dust was expected because parts that are cleaned in this system may be coated with paint containing metal pigments. A breathing zone sample and an area sample were collected because this task had not previously been performed. Iron was the only metal observed in the sample (Table XI). 
Table XI. Sample Data, Bead Blaster

\begin{tabular}{llccccc}
\hline $\begin{array}{l}\text { Sample } \\
\text { Type }\end{array}$ & Metal & $\begin{array}{c}\text { RDL } \\
(\mathrm{mg})\end{array}$ & $\begin{array}{c}\text { Concentration } \\
(\mathrm{mg} / \mathrm{m} 3)\end{array}$ & $\begin{array}{c}\text { TWA } \\
(\mathrm{mg} / \mathrm{m} 3)\end{array}$ & $\begin{array}{c}\text { Sample } \\
\text { Volume } \\
(\mathrm{L})\end{array}$ & $\begin{array}{c}\text { Sample } \\
\text { Time } \\
(\mathrm{min})\end{array}$ \\
\hline $\mathrm{P}$ & Lead & 0.001 & $<0.0080$ & $<0.0010$ & 122.09 & 61 \\
& Iron & 0.005 & 0.106 & 0.013 & & \\
& & & & & & \\
$\mathrm{~A}$ & Lead & 0.001 & $<0.0080$ & $\mathrm{~N} / \mathrm{A}$ & 121.48 & 61 \\
& Iron & 0.005 & $<0.0410$ & $\mathrm{~N} / \mathrm{A}$ & & \\
\hline
\end{tabular}

Note: Sample Type: $\mathrm{P}=$ Personal, $\mathrm{A}=$ Area. Samples submitted for metal scan.

Two employees performing work task, one breathing zone and one area sample collected.

$<$ indicates sample data below detection limit.

\section{Noise}

The noise similar exposure group consists of 45 mechanics of which 27 mechanics or $66 \%$ were monitored for noise exposure. Noise exposure levels for 23 employees were sampled one time and 4 mechanics were sampled on two separate occasions. The monitoring was initiated in late February with intermittent sampling over twelve days through early August. Mechanics were randomly selected for monitoring between Monday and Thursday with $7 \%$ occurring on Monday and $93 \%$ of the monitoring was conducted on the remaining three days.

Twenty six 8-hour TWA personal noise dosimetry samples were collected during routine work activities. Table XII provides a summary of exposure levels by equipment use which suggests a potential exposure above $85 \mathrm{dBA}$ is probable and dependent on the tool and duration. Additional sampling data is located in Appendix D. Sample results were evaluated for normality using a probability plot and determined to be lognormally distributed. The Shapiro-Wilkes test for normality confirmed a lognormal goodness of fit. 
Table XII. Noise Level Comparison of Equipment

\begin{tabular}{cccc}
\hline Tool & $(\mathrm{N})$ & Mean TWA $(\mathrm{dB})$ & $\mathrm{SD}(\mathrm{dB})$ \\
\hline Impact Wrench & 9 & 82.78 & 3.55 \\
Grinding Wheel & 7 & 85.68 & 3.99 \\
Small Air Tools & 4 & 81.23 & 2.37 \\
\hline
\end{tabular}

The arithmetic mean for the sample set was calculated to be $82.3 \mathrm{~dB}$, and the median was $81.7 \mathrm{~dB}$ with an upper $95 \%$ confidence level of $83.75 \mathrm{~dB}$. Table XIII provides a comparison of the average TWA between the job classifications. Noise exposure TWAs ranged from $77.7-90.9 \mathrm{~dB}$ with $23 \%$ of the monitoring data exceeding the ACGIH OEL of $85 \mathrm{dBA}$. The higher noise levels were associated with use of the hand-held grinding wheels followed by use of the impact wrench.

Table XIII. Noise Data Summary TWA Results Between Job Classification

\begin{tabular}{lccccc}
\hline Job Classification & $(\mathrm{N})$ & $\begin{array}{c}\text { Mean TWA } \\
(\mathrm{dB})\end{array}$ & $\mathrm{SD}(\mathrm{dB})$ & Median $(\mathrm{dB})$ & $\begin{array}{c}95 \% \mathrm{UCL} \\
(\mathrm{dB})\end{array}$ \\
\hline All Mechanics & 26 & 82.33 & 3.81 & 81.7 & 83.72 \\
Light Equipment & 20 & 82.10 & 3.48 & & \\
Heavy Equipment & 6 & 83.08 & 5.06 & & \\
\hline
\end{tabular}




\section{DISCUSSION}

The objective of this study was to assess the potential chemical and physical exposures to mechanics for routine work activities that involve servicing various types of equipment and vehicles. This assessment evaluated and defined the similar exposure groups, monitored levels of benzene, lead and noise in the workplace, and characterized their exposure profiles.

Although a qualitative industrial hygiene exposure assessment had been conducted previously, the data used to evaluate exposures was either too old or insufficient to adequately characterize the exposure potential. Levels of benzene, lead, and noise were evaluated for compliance with the OELs.

\section{Similar Exposure Group}

Stratifying employees into similar exposure groups based on the workers having the same general exposure profile for an agent is an efficient hazard assessment method. Quantitative characterization of one or a few employees is then considered representative of the exposures for everyone in the group (Ignacio 2006). An approach often used for defining SEGs is to classify them by their job title. This classification method had been used for the previous qualitative exposure assessment of the fleet shops. Each facility was considered independent and the mechanics were classified by their specific job title.

The initial step in this assessment was to qualitatively evaluate the hazards for each of the existing SEGs and determine if the classification by job title and building correctly defined the similar exposure groups. Following discussions with the mechanics from each of the buildings about their job functions, work area observations, and information reviewed 
from the chemical inventory and material safety data sheets the SEGs were defined by environmental agent and task. The mechanics' work activities varied daily but the frequency and duration of chemical and pneumatic tool usage were comparable for exposure to VOCs and noise.

The SEG for exposure to lead dust is a subset of the mechanic group limited to employees who physically remove paint or surface coatings from vehicles with grinding wheels or who sand paint and surface filler materials during auto body reconstruction. Surface preparation work is an infrequent activity typically of short duration for the light and heavy equipment mechanics doing small scale repair tasks. If a job requires more than one can of spray paint to recoat a surface, the work must be performed by the auto body mechanics with the use of ventilated sanding equipment. Local exhaust ventilation is used for work tasks where airborne dust is expected and other exposure controls are not feasible.

\section{Benzene}

Benzene is found as an unintentional ingredient in solvent used by industry due to its ubiquitous present in feedstock used to manufacture solvents (Robbins et al. 2012). Exposure to airborne concentrations approaching the occupational exposure limit may be possible depending on factors such as the benzene concentration in the product, the frequency and duration of product usage and the use of engineering controls in the work area such as ventilation (Kopstein 2006). Because benzene is a carcinogen and may be present in petroleum-derived products in varying concentrations at or below $1 \% \mathrm{w} / \mathrm{w}$ there has been contention as to whether airborne benzene exposure can occur and at what airborne concentration (Kopstein 2006, Williams et al. 2008). 
Airborne concentrations for benzene, toluene and xylene were observed in grab sampled collected in three mechanic shops during regular working hours (Badjagbo et al. 2010). The highest levels observed were $0.006 \mathrm{ppm}, 0.316$ and 0.07 for benzene, toluene and xylene, respectively. Bejan et al. found airborne concentrations for acetone ranging from 7.8 $-35 \mathrm{ppm}$, toluene ranging from $3.1-31 \mathrm{ppm}$ and xylene from $0.9-3.6 \mathrm{ppm}$ in area samples obtained from an auto body shop paint mixing room. The highest airborne toluene concentration was thought to come from an open solvent container in a room with limited ventilation. In a simulated study by Williams et al. the airborne benzene concentration from $10 \mathrm{ml}$ of product use over a 15 minute period resulted in $2.7 \mathrm{ppm}$ and an 8-hour TWA of 0.08 ppm. The product used in the study was spiked with benzene to a concentration of $3 \%$.

Airborne benzene concentrations in this current study of the fleet shops were all below the reporting detection limit and similar to those observed by Badjagbo et al. The initial exposure profile identified activities with potential exposure to benzene. These sources included use of degreasing solvents, gasoline, lubricants, spray paints and vehicle exhaust. Air monitoring was part of the evaluation process because there past VOC exposure data not available. The material safety data sheets for the chemicals regularly used by the mechanics did not identify benzene as a constituent although other VOCs were identified that may contain trace amounts of benzene. VOC concentrations observed in the fleet shops were either below the detection limit or less than $10 \%$ of the ACGIH OEL. Monitoring data obtained during this assessment indicates no exposure above background levels to benzene and exposure to other VOCs is controlled through ventilation, and limited product use. 
Toluene, hexane, VM\&P naphtha, xylene and ethyl benzene can contain benzene concentrations $\leq 0.1 \%$ and thus not required to be listed on an MSDS. Nevertheless, airborne exposures could exceed the occupational exposure limit (Kopstein 2006). For example, benzene was found at a concentration of $0.5 \mathrm{ppm}$ in the air of a warehouse with a 30 gallon tank of mineral spirits intentionally spiked with a concentration of $0.058 \%$ (Fedoruk et al. 2003). This comparatively high air residue was found in a worker's breathing zone and was likely influenced by the buildings limited ventilation. When extrapolated from a 1-h sample to an 8-h workday, the air concentration could have exceeded the OEL. Many of the benzene exposure studies discussed in the literature were designed to evaluate past exposures to workers from use of a specific product (Williams et al 2008, Fedoruk et al. 2003). However, these data may be of limited use today because of changes in product formulations and current workplace practices.

A simulated study was designed to test the theory of exposure during use of products containing trace amounts of benzene $(<0.1 \%)$. This study involved pouring $10 \mathrm{ml}$. of a toluene solvent onto a shop rag and wiping a metal surface until the solvent had fully evaporated. The highest airborne concentration obtained from the 15 minute breathing zone samples was $0.0088 \mathrm{ppm}$ (Robbins et al. 2012). The sample data observed from this study is comparable to the measured benzene concentrations during a similar activity monitored in the fleet shops. 
The mechanic's work task involved using a degreasing solvent (DX320) poured on to a shop rag to clean metal surfaces inside a van. The material safety data sheet for the solvent listed Ligroine, CAS number 8032-32-4 (VM\&P naphtha) as the main ingredient at $60-$ $100 \%$ and toluene at $0.1-1 \%$. Benzene and VM\&P naphtha were not detected in the area or breathing zone samples but toluene was observed at $0.99 \mathrm{ppm}$ in the breathing zone sample and $19.72 \mathrm{ppm}$ in the area sample.

Many of the benzene exposure studies discussed in the literature were designed to evaluate past exposure to workers from use of a specific product (Williams et al 2008, Fedoruk et al. 2003). However, these data may be of limited use today because of changes in product formulations and current workplace practices.

For example, the sampling data obtained by Fedoruk and referred to by Kopstein is from a designed experiment using a solvent product with a known starting benzene concentration that was added just prior to the start of the experiment (Kopstein 2006). Benzene has a fairly high vapor pressure and will evaporate at a faster rate than some of the other constituents in the solvent. For the fleet shop exposure assessment, the amount of benzene in the petroleum-derived lubricants and solvents was unknown. Bulk product samples were not obtained and analyzed for benzene content which is typically done to determine the initial solvent concentration for the simulated exposure assessments such as the Fedoruk study. 


\section{Lead}

While the use of lead in paint has been reduced, older automotive paint may still pose a hazard (Enander et al. 2004). Bulk dust samples of paint and body filler dusts from auto body shops in the Rhode Island area contained high lead levels (Enander et al. 2002) Significant amounts of lead are still used in paints as pigments and as driers (Blando et al. 2007).

The fleet shop mechanics maintain vehicles and equipment in varying age categories. While most of the passenger type vehicles and pickup trucks are newer, commercial motor vehicles, heavy construction equipment and cranes are typically older and the paints have a higher potential for containing metal pigments. Structural repair work often requires welding and part fabrication. However, the paint must be removed prior to any welding which is accomplished with a hand-held grinding wheel. When the equipment requires more than one can of spray paint or additional body work is necessary, the vehicle is repaired by the auto body mechanics. Pre-painting preparation in the auto body shop typically involves using an orbital sander to remove paint and body filler compound.

Prior to this assessment, insufficient sample data was available to fully characterize the mechanics' exposure potential to lead during grinding, welding and sanding activities. Task-based breathing zone samples were collected during all work tasks with potential lead exposure from March 5 -August 7, 2012. The air samples were analyzed for lead in addition to other metals potentially present in the surface coatings. Sampling was conducted on 3 welding and grinding tasks, 2 paint and body filler sanding jobs and during filter and media 
replacement on the bead blaster. This last task was monitored because the mechanics use this equipment to clean paint, rust or other debris from small vehicle and equipment parts.

Airborne lead concentrations were observed in an auto body shop ranging from below the detection limit to $0.12 \mathrm{mg} / \mathrm{m}^{3}$ (Enander et al. 2004). Twenty one samples were collected from two auto body repair shops that had dedicated body men who sanded paint and body filler 6-8 hours per day for 5 days a week. However, airborne lead concentrations were below the OSHA PEL for 18 of the 21 samples collected. Unlike the Enander et al. 2004 study, lead was not found in the samples obtained during this evaluation of the fleet shops. The other metals observed were at concentrations less than $10 \%$ of the ACGIH OEL. Iron was found in the welding and grinding samples at levels between $10-20 \%$ of the OEL.

These low airborne metal concentrations suggest the exposures are acceptable with the use of local exhaust ventilation (LEV). Because lead or other metals may be present in the paints on older equipment or vehicles, activities such as sanding and grinding and welding on or near painted surfaces, exposure controls including LEV and good hygiene practices must be used.

\section{Noise}

The fleet shop mechanics work with or around tools and equipment that generate noise levels that range from $70-105 \mathrm{~dB}$. Noise dosimetry monitoring data obtained during normal working hours ranged between $78-91 \mathrm{~dB}$ for this survey. Noise levels observed varied depending on the tools that were being used, the type of work surface, the work location and 
the task duration. The mean TWA for a mechanic working with a pneumatic tool such as an impact wrench was $83 \mathrm{~dB}$ and the mean TWA during use of a grinding wheel was $86 \mathrm{~dB}$.

A NIOSH exposure assessment on vehicle mechanics found noise levels exceeding the NIOSH REL in 5 of the 8 noise dosimetry samples collected. The TWA monitoring data ranged from $82.8 \mathrm{dBA}-101.7 \mathrm{dBA}$. The highest exposure was obtained on a mechanic using an impact wrench to replace tires. (NIOSH 2008). Bejan et al., 2011 evaluated the noise levels in an auto body shop on two occasions. The highest noise level found during the first visit was $89 \mathrm{dBA}$ as an ACGIH TWA and during the second visit noise levels ranged from a low of $81.97 \mathrm{dBA}-91.82 \mathrm{dBA}$ TWA. Additional monitoring on mechanics during this same visit found TWA noise levels from $85.68 \mathrm{dBA}-86.21 \mathrm{dBA}$.

Noise levels observed in the fleet shops during this survey were consistent with other mechanic shops. A difference between our shops and other mechanic shops is the variability of the work scope for the fleet services mechanics. The tire and lube mechanics typically perform the same types of activities on a daily basis but the frequency of tire repair to service lubrication is not consistent. Our auto body shop has two mechanics that perform both prepainting preparation work tasks and finish work. This work task variability will also influence the noise levels experienced by the auto body mechanics because their exposure duration is typically shorter than a dedicated auto body preparation technician.

The exposure rating for the mechanics prior to this assessment suggested noise levels were expected between $50-100 \%$ of the OEL for the light equipment, auto body, heavy 
equipment oiler and construction mechanics. This exposure rating was based on 8 noise dosimetry samples and equipment sound level measurements obtained during use. TWA exposure levels from noise dosimetry monitoring for the heavy equipment mechanics ranged from 86 - 95 dBA in 2009 and from 78 - 90 dBA in 2012 and the light equipment mechanics' TWA noise levels ranged from $77-89 \mathrm{dBA}$ in 2009 and from $78-89 \mathrm{dBA}$ in 2012. Noise levels for equipment such as the grinding wheel ranged from a low of $86 \mathrm{~dB}$ to a high of 105 $\mathrm{dB}$ and the impact wrenches had noise levels between $95 \mathrm{~dB}-98 \mathrm{~dB}$. The exposure rating for all of the mechanics following this assessment is better characterized as a 4 indicating that exposures are expected to be above the OEL.

The noise levels observed support the use of hearing protective equipment to reduce the potential for overexposure. The mechanics are in a hearing conservation program and are required to wear hearing protection when working with pneumatic tools, power tools, working around operating engines on large trucks or equipment, air compressors and generators. The hearing protection provided must be easy to use and must reduce the noise level enough to protect the employee's hearing. Ear plugs which generally have a high manufacturer noise reduction rating, requires a person to roll them between their fingers like a golf tee before being inserted into the ear canal. Most employees do not follow the directions to properly insert the ear plugs and may not receive sufficient noise reduction to prevent an overexposure and eventual hearing loss. Another hearing protection option for use in a work environment such as a mechanic shop are the banded ear plugs which are inserted into the ear canals and held in place by plastic bands that allow the employee to carry them around their neck when not in use. These are simple to use, do not require extra steps for correct insertion and also 
prevent the potential for getting grease or dirt into the ear canal which could occur during the use of the formable ear plugs. The downside to the banded plugs is their lower noise reduction rating. 


\section{CONCLUSION}

The data obtained during this survey was useful for characterizing the mechanic's risk of exposure to VOCs, metal dusts and noise. Benzene was not found in the 8-hour TWA or the task-based samples. Airborne concentrations of acetone, ethyl ether and toluene were observed at levels less than $10 \%$ of the ACGIH OEL and exposures are acceptable. This data suggests the exposures are controlled through the use of ventilation and minimal use of chemicals.

Sample results for lead were all below the limit of detection. There were other metals observed in the dust samples at concentrations less than $10 \%$ of the OEL with the exception of iron which was found in one sample at $10 \%$ of the OEL. The airborne metal dust concentrations observed suggests the exposures are acceptable and are controlled through the use of local exhaust ventilation.

Noise level data obtained in 2009 provided a good indication the mechanics had a potential for exposure above the TLV. Noise dosimetry conducted during this evaluation confirmed that noise exposures for $23 \%$ of the employees monitored were above the TLV. Noise exposure is controlled through the use of hearing protection devices that are required to be worn during use of pneumatic tools, power tools, engine noise, compressors and generators. With the use of hearing protection, an exposure rating of 2 would be more appropriate. This rating suggests that exposures are controlled between $10-50 \%$ of the OEL with the use of hearing protection. 


\section{LITERAT URE CITED}

\section{Public Laws}

Occupational Safety and Health Act of 1970 (OSH Act), as amended, Public Law 91-596, 84 Stat. 1690, 29 U.S.C. 651-678.

\section{Code of Federal Regulations}

10 CFR 851.21, Code of Federal Regulation, Title 10, Part 851. DOE Worker Safety and Health Program

29 CFR 1910.95, Code of Federal Regulation, Title 29, Part 95. Noise

29 CFR 1910.1025, Code of Federal Regulation, Title 29, Part 1025. Lead

29 CFR 1910.1028, Code of Federal Regulation, Title 29, Part 1028. Benzene

29 CFR 1910.1200, Code of Federal Regulations, Title 29, Part 1200. Hazard Communication.

3M Technical Data Bulletin 1028 [Internet]. Organic Vapor Monitor Sampling and Analysis Guide, 3M. Available from:

http:/www.3m.com/intl/ca/english/market/traffic/ohes/pdf pub/1028.pdf (accessed May 2, 2012)

Almaguer D., G.E. Burroughs and A. Echt "Control technology and exposure assessment for electronic recycling operations, Elkton Federal Correctional Institution, Elkton, Ohio. [Internet] U.S. Department of Health and Human Services, Public Health Service, Centers for Disease Control and Prevention, National Institute for Occupational Safety and Health, Control Technology. Cincinnati, OH. Report No. EPHB-326-12a. [accessed 2013 March 15] Available from: www.cdc.gov/niosh/surveyreports/pdfs/326-12a.pdf

American Conference of Governmental Industrial Hygienists (ACGIH): Documentation of the threshold limit values and biological exposure indices. Benzene. Threshold Limit Value [Standard] Cincinnati, Ohio: ACGIH 2001.

American Conference of Governmental Industrial Hygienists (ACGIH): Threshold Limit values for chemical substances and physical agents and biological exposure indices and Biological Exposure Indices. Threshold Limit Value [Standard] Cincinnati, Ohio: ACGIH 2012. 
American Industrial Hygiene Association (AIHA). Guidelines for noise exposure control. American Industrial Hygiene Association Journal 28:5 418-424 (1967).

Agency for Toxic Substances and Disease Registry. Toxicological Profile for Lead. [Internet]. Atlanta, GA: ATSDR [updated 2011 March 3] [Accessed 2012 September 4] Available from: http://www.atsdr.cdc.gov/toxprofiles/tp13.html

Badjagbo K, Loranger S, Moore S, Tardif R, and Sauve S. BTEX exposures among automobile mechanics and painters and their associated health risks. Human and Ecological Risk Assessment 2010;16 301-316.

Bejan A, Brosseau L.M, and Parker D.L. Exposure assessment in auto collision repair shops. Journal of Occupational and Environmental Hygiene 2011;8 401-408.

Berger E.H, Royster L.H, Royster J.D, Royster, Driscoll D.P, Layne M,. The noise manual. $5^{\text {th }}$ Ed. Fairfax, Virginia American Industrial Hygiene Association Press; 2003.

Blando J, Lefkowitz D, Valiante D, Gerwel B, Bresnitz E. Survey of current lead use, handling, hygiene, and contaminant controls among new jersey industries. Journal of Occupational and Environmental Hygiene 2007;4 539-546.

Byrne D, Reeves R. Analysis of nonstandard noise dosimeter microphone positions. Journal of Occupational and Environmental Hygiene 2008; 5(3) 197-209.

Centers for Disease Control and Prevention (US). Noise and Hearing Loss Prevention Power Tools Database [Internet]. Atlanta, GA: CDC [Accessed 2010 November 10]. Available from: http://wwwn.cde.gov/niosh-sound-vibration

Concha-Barrientos M, Campbell-Lendrum D, Steenland K. Occupational Noise: assessing the burden of disease from work-related hearing impairment at national and local levels. World Health Organization, (WHO) Environmental Burden of Disease Series No. 9. 2004. (accessed 2013 March 15,) Available from:

http:/www.who.int/quantifying ehimpacts/publications/9241591927/en/index.html

Department of Energy 2012a. Hanford overview and history [Internet]. Richland, WA; DOE [updated 2012 September, 12; Accessed 2013 February 12]. Available from: http://www.hanford.gov/page.cfm/HanfordOverviewandHistory 
Department of Energy 2012b. Hanford contractors [Internet]. Richland, WA; DOE [updated 2012 September, 12; Accessed 2013 February 12]. Available from:

http:/www.hanford.gov/page.cfm/HanfordOverviewandHistory

Department of Energy (US). The office of health, safety and security; worker safety and health program; Regulations (10CFR) [Internet\}. Washington D.C.: DOE Standard - 10 CFR 851 [accessed 2013 March 7]. Available from:

http:/www.hss.energy.gov/healthsafety/wshp/rule851/851final.html

DiNardi S. 2003. The occupational environment: its evaluation, control and management. $3^{\text {rd }}$ Ed. Fairfax, Virginia: American Industrial Hygiene Association Press

Egeghy P, Nylander-French P, Gwin K, Hertz-Picciotto I, Rappaport S. Self-collected breath sampling for monitoring low-level benzene exposures among automobile mechanics. Ann. Occup. Hyg. 2002;46(5) 489-500.

Elliot L, Oestenstad R. Evaluation of the predictive abilities of a qualitative exposure assessment model. Journal of Occupational and Environmental Hygiene 2007;4 440-447.

Enander R, Gute D, Cohen H, Linfield L, Desmaris A, Missaghian R. Chemical characterization of sanding dust and methylene chloride usage in automotive refinishing: implications for occupational and environmental health. AIHA Journal. 2002;63(6 ) 741-749.

Enander R, Cohen H, Gute D, Brown L, Desmaris A, Missaghian R. Lead and methylene chloride exposures among automotive repair technicians. Journal of Occupational and Environmental Hygiene 2004;1 119-125.

Environmental Protection Agency (US). Toxicological review of benzene [Internet]. Washington D.C. EPA [2002]. [Accessed 2012 March 23]. Available from: http://www.epa.gov/iris/toxreviews/0276tr.pdf

Fedoruk M, Bronstein R, Kerger B. Benzene exposure assessment for use of a mineral spirits based degreaser. Applied Occupational and Environmental Hygiene. 2003;18(10) 764-771.

Forouharmajd F, Nassiri P, Monazzam M. Noise pollution of air compressor and its noise reduction procedures by using an enclosure Int J Env Health. 2012;1 20. 
Hansen D, Adams G, Hochberg R. Comparison of sampling strategies used during a machine shop noise survey. Applied Industrial Hygiene. 1989; 4(3) 75-80.

Hazard Communication Standard [Internet]. Occupational Safety and Health Administration (OSHA), U.S. Department of Labor. HCS [accessed 2013 March 15] Available from: http://www.osha.gov/dsg/hazcom/index.html

Ignacio J, Bullock W. 2006. Strategy for assessing and managing occupational exposures. $3^{\text {rd }}$ Ed. Fairfax, Virginia: American Industrial Hygiene Association Press.

Integrated Risk Information System (US). Lead and compounds (inorganic) [Internet]. Washington D.C. IRIS [Updated 2013 January 24; accessed 2013 January 28]. Available from http://www.epa.gov/iris/subst/0277.htm

International Agency for Research on Cancer. Monographs on the evaluation of carcinogenic risks to Human: Volume 29 [Internet]. Lyons, France: IARC [updated 1999 April 19; accessed 2012 December 2]. Available from:

http://monographs.iarc.fr/ENG/Monographs/vol29/volume29.pdf

International Agency for Research on Cancer. Monographs on the evaluation of carcinogenic risks to Human: inorganic and organic lead compounds volume 87 [Internet]. Lyons, France: IARC [updated 2006 April 19; accessed 2012 December 22]. Available from: http://monographs.iarc.fr/ENG/Monographs/vol87/

International Agency for Research on Cancer. Monographs on the evaluation of carcinogenic risks to humans [Internet]. Lyons, France: IARC [updated 2012 November; accessed 2013 March 25]. Available from: http://monographs.iarc.fr/ENG/Classification/index.php Kardous C, Willson R. Limitations of Using Dosimeters in Impulse Noise Environnments. Journal of Occupational and Environmental Hygiene. 2004; 1(7) 456-46.

Klaasen C, Watkins J, editors. 1999. Casarett \& doull's toxicology; the basic science of poisons. $5^{\text {th }}$ Ed. New York: McGraw-Hill.

Klaassen C. editor. 2008. Casarett and doull's toxicology: the basic science of poisons. $7^{\text {th }}$ Ed. New York: McGraw-Hill. 
Kopstein M. Potential uses of petrochemical products can result in significant benzene exposures: MSDSs must list benzene as an ingredient. Journal of Occupational and Environmental Hygiene 2006;3 1-8.

Kopstein M. Estimating airborne benzene exposures from air monitoring data for mineral spirits." Journal of Occupational and Environmental Hygiene 2011;8(5) 300-309

Lan Q, Zhang L, Li G, Vermeulen R, Weinberg R, Dosemeci M, Rapaport S. Hematotoxicity in workers exposure to low levels of benzene. Science. 2004;306(5702) 1774-1776.

Muldoon T. Response variation of the microphone worn on the human body (RI-7810) [Internet]. Washington D.C.: United States Department of the Interior, U.S. Bureau of Mines; 1973. Available from:

http://babel.hathitrust.org/cgi/pt?id=mdp.39015078521559;page=root;view=image;size $=100 ; \mathrm{s}$ eq $=4$

National Institute for Occupational Safety and Health (NIOSH). Health hazard evaluation report: matrix auto body. [Internet]. Englewood, Colorado: NIOSH [1996] [Accessed 2012 July 3]. Available from: http://www.cdc.gov/niosh/hhe/reports/pdfs/1995-0406-2609.pdf

National Institute for Occupational Safety and Health (NIOSH). Criteria for a Recommended Standard Occupational Noise Exposure. [Internet]. Cincinnati, Ohio: NIOSH [1998] ; [Accessed 2012 July 23]. Available from: http://www.cdc.gov/niosh/docs/98-126/

National Institute for Occupational Safety and Health (NIOSH). NIOSH Manual of Analytical Methods, Fourth Edition. Elements by ICP, Method 7300. [Internet]. Cincinnati, Ohio: NIOSH [2002]; [Accessed 2012 March 20]. Available from: http://www.cdc.gov/niosh/docs/2003-154/pdfs/7300.pdf

National Institute for Occupational Safety and Health (NIOSH). Health hazard evaluation report: Navajo Agricultural Products Industry. [Internet]. Cincinnati, OH: NIOSH [2004] [Accessed 2012 July 22]. Available from: http://www.cdc.gov/niosh/hhe/reports/pdfs/20040014-2929.pdf

National Institute for Occupational Safety and Health (NIOSH). Health hazard evaluation report: evaluation of potential noise hazards to mechanics and 911 dispatchers at a fire department. [Internet]. Anchorage, Alaska: NIOSH [2008] [Accessed 2012 July 23]. Available from: http:/www.cdc.gov/niosh/hhe/reports/pdfs/2007-0235-3064.pdf 
National Toxicology Program. Report on Carcinogens background document for lead and lead compounds. [Internet] Triangle Park, NC: NTP [updated 2003 May 8; accessed 2013 January 3]. Available from: http://ntp.niehs.nih.gov/ntp/newhomeroc/roc11/Lead-Public.pdf

National Toxicology Program. Report on carcinogens. $12^{\text {th }}$ edition. [Internet] Triangle Park, NC: NTP [updated 2011 March 7; accessed 2013 March 20]. Available from: http://ntp.niehs.nih.gov/?objectid=03C9AF75-E1BF-FF40-DBA9EC0928DF8B15

National Toxicology Program (NTP 2012). NTP monograph of health effects of low-level lead [Internet]. Triangle Park, NC: NTP [updated 2013 February 14; accessed 6 February 2013]. Available from: http://ntp.niehs.nih.gov/?objectid=4F04B8EA-B187-9EF29F9413C68E76458E

Nelson N, Kaufman J. Employees exposed to lead in washington state nonconstruction workplaces: a starting point for hazard surveillance. American Industrial Hygiene Association Journal. 1998;59(4) 269-277.

Occupational Safety and Health Administration (US). Inspection procedures for the hazard communication standard; directive CPL 01-01-038 [Internet]. Washington D.C.: OSHA [updated 1998 March 20; accessed 2012 December 6]. Available from: http://www.osha.gov/pls/oshaweb/owadisp.show_document?p_table=DIRECTIVES\&p_id=1 551

Occupational Safety and Health Administration (US). Method 1005 sampling and analytical method for benzene [Internet]. Washington D.C.: OSHA [updated 2002 September; accessed 2013 January 29]. Available from:

http:/www.osha.gov/dts/sltc/methods/validated/1005/1005.html

Occupational Safety and Health Administration (US). Permissible exposure limit [Internet]. Washington D.C.: OSHA [updated 2006 October 30; accessed 2013 January 7]. Available from: http://www.osha.gov/dsg/topics/pel/index.html 
Occupational Safety and Health Administration (US). Occupational safety and health standard; occupational noise exposure [Internet]. Washington D.C.: OSHA Standard 29 CFR 1910.95 [updated 2008 December 12; accessed 2013 February 1]. Available from http://www.osha.gov/pls/oshaweb/owadisp.show_document?p_table=STANDARDS\&p_id=9 735

Occupational Safety and Health Administration (US). Occupational safety and health standard; toxic and hazardous substances [Internet]. Washington D.C.: OSHA Standard 29 CFR 1910.1028 [updated 2012 March 26; accessed 2013 February 5]. Available from http:/www.osha.gov/pls/oshaweb/owadisp.show_document?p_table=STANDARDS\&p_id=1 0042

Occupational Safety and Health Administration (US). Occupational safety and health standard; Regulations (Standards - 29CFR) [Internet]. Washington D.C.: OSHA Standard - 29 CFR 1910.05 [accessed 15 March 2013] Available from:

http:/www.osha.gov/pls/oshaweb/owasrch.search form?p doc type=STANDARDS\&p toc 1 $\underline{\text { evel }=1 \& p \text { keyvalue }=1910}$

Passchier-Vermeer W, Passchier W. Noise exposure and public health. Environmental Health Perspectives 2000;18(11) 123-131.

Paustenbach D, The practice of exposure assessment: a state-of-the-art review. Journal of Toxicology and Environmental Health, Part B. 2000;3 179-291.

Periago J, PradoC. Evolution of occupational exposure to environmental levels of aromatic hydrocarbons in service stations. Ann. Occup. Hyg. 2004;49(3) 233-240.

Plog B, Schonfield J, editors. 1996. Fundamentals of industrial hygiene. 5th ed. Itasca, Il: National Safety Council Press.

Rappaport S, Kim S, Lan Q, Li G, Vermeulen R, Waidyanatha S, Zhang L, Yin S, Smith M, Rothman N. Human benzene metabolism following occupational and environmental exposures. Chemico-Biological Interactions. 2010;184 189-195.

Robbins C, Krause M, Atallah R, Plisko M.. " comparison of exposure measurements to near field-far field modeled results for benzene and base solvents during a cleaning process using plain or $0.1 \%$ benzene spiked toluene and xylene. Journal of chemical Health and Safety. 2012;19(6) 3-11. 
Rousseau M, Parent M, Nadon L, Latreille B, Siemiatycki J. Occupational exposure to lead compounds and risk of cancer among men: a population based case-control study." American Journal of Epidemiology 2007;166(9) 1005-1014.

Spear J. Industrial hygiene exposure assessments; worst-case versus random sampling. Professional Safety. 2005; 39-44.

Spencer E. Assessment of equipment operator's noise exposure in western underground gold and silver mines. Mining Engineering: Society for Mining, Metallurgy and Exploration Inc. $2010 ; 62(3)$ 34-38.

Toxicology Data Network United States National Library of Medicine (US). Lead elemental [Internet]. Bethesda, MD: Toxnet [updated 2010 January 21; accessed 2012 December 15]. Available from: http://toxnet.nlm.nih.gov/cgi-

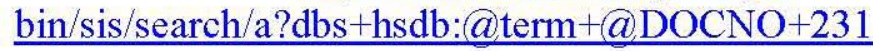

Van Wijngaarden E, Stewart P. Critical literature review of determinants and levels of occupational benzene exposure for united states community-based case-controlled studies. Applied Occupational and Environmental Hygiene. 2003;18(9) 678-693.

Williams P, Knutsen J, Atkinson C, Madl A, Paustenbach D. Airborne concentrations of benzene associated with the historical use of some formulations of liquid wrench. Journal of Occupational and Environmental Hygiene. 2007; 4 547-561.

Williams P, Panko J, Unice K, Brown J, Paustenbach D. Occupational exposures associated with petroleum-derived products containing trace levels of benzene. Journal of Occupational and Environmental Hygiene. 2008;5 565-574.

Wilson M, Hammand S, Nicas M, Hubbard A. Worker exposure to volatile organic compounds in the vehicle repair industry. Journal of Occupational and Environmental Hygiene. 2007; 4 301-310. 
APPENDICES 


\section{APPENDIX A}

Similar Exposure Group Hazard Evaluation Table

\begin{tabular}{|c|c|c|c|c|c|c|}
\hline $\begin{array}{l}\text { Job Title \& No. } \\
\text { Employees }\end{array}$ & Task with potential exposure & Exposure Control & $\begin{array}{l}\text { Exposure } \\
\text { Rating }\end{array}$ & $\begin{array}{l}\text { Basis for } \\
\text { Exposure }\end{array}$ & $\begin{array}{l}\text { Exposure } \\
\text { Judgment }\end{array}$ & $\begin{array}{l}\text { Action to } \\
\text { be taken }\end{array}$ \\
\hline $\begin{array}{c}\text { Light Duty } \\
\text { Mechanics (16) }\end{array}$ & $\begin{array}{l}\text { Gasoline, degreasers, spray } \\
\text { paints, lubricants, vehicle } \\
\text { exhaust }\end{array}$ & $\begin{array}{l}\text { Natural ventilation / } \\
\text { gloves }\end{array}$ & 3 & $\begin{array}{l}\text { Literature } \\
\text { review, no } \\
\text { previous data }\end{array}$ & Uncertain & $\begin{array}{c}\text { Air } \\
\text { monitoring }\end{array}$ \\
\hline $\begin{array}{l}\text { Tire \& Lube } \\
\text { Mechanics (4) }\end{array}$ & $\begin{array}{l}\text { Degreasers, spray paints, oils } \\
\text { and lubricants, vehicles } \\
\text { exhaust }\end{array}$ & $\begin{array}{l}\text { Natural ventilation / } \\
\text { gloves }\end{array}$ & 3 & $\begin{array}{l}\text { Literature } \\
\text { review, no } \\
\text { previous data }\end{array}$ & Uncertain & $\begin{array}{c}\text { Air } \\
\text { monitoring }\end{array}$ \\
\hline $\begin{array}{l}\text { Auto Body / Paint } \\
\text { Mechanics (2) }\end{array}$ & $\begin{array}{l}\text { Spray paints, degreasers, } \\
\text { vehicle exhaust }\end{array}$ & $\begin{array}{l}\text { Natural ventilation / } \\
\text { gloves / Respirator }\end{array}$ & 3 & $\begin{array}{l}\text { Literature } \\
\text { review, no } \\
\text { previous data }\end{array}$ & Uncertain & $\begin{array}{c}\text { Air } \\
\text { monitoring }\end{array}$ \\
\hline $\begin{array}{l}\text { Heavy Duty } \\
\text { Mechanics (17) }\end{array}$ & $\begin{array}{l}\text { Gasoline, degreasers, spray } \\
\text { paints, lubricants, parts } \\
\text { washer, vehicle exhaust }\end{array}$ & $\begin{array}{l}\text { Natural ventilation / } \\
\text { gloves }\end{array}$ & 3 & $\begin{array}{l}\text { Literature } \\
\text { review, no } \\
\text { previous data }\end{array}$ & Uncertain & $\begin{array}{c}\text { Air } \\
\text { monitoring }\end{array}$ \\
\hline $\begin{array}{l}\text { Heavy Duty Oiler } \\
\text { Mechanics (4) }\end{array}$ & $\begin{array}{l}\text { Degreasers, lubricants, } \\
\text { vehicle exhaust }\end{array}$ & $\begin{array}{l}\text { Natural ventilation / } \\
\text { gloves }\end{array}$ & 2 & $\begin{array}{l}\text { Literature } \\
\text { review, no } \\
\text { previous data }\end{array}$ & Uncertain & $\begin{array}{c}\text { Air } \\
\text { monitoring }\end{array}$ \\
\hline $\begin{array}{l}\text { Construction } \\
\text { Mechanics (2) }\end{array}$ & $\begin{array}{l}\text { Gasoline, degreasers, spray } \\
\text { paints, lubricants, vehicle } \\
\text { exhaust }\end{array}$ & $\begin{array}{l}\text { Natural ventilation / } \\
\text { gloves }\end{array}$ & 3 & $\begin{array}{l}\text { Literature } \\
\text { review, no } \\
\text { previous data }\end{array}$ & Uncertain & $\begin{array}{c}\text { Air } \\
\text { monitoring }\end{array}$ \\
\hline
\end{tabular}

Note: Mechanics work 4 days/week, 10 hours/day. Chemical usage is intermittent throughout the work day.

${ }^{A}$ Exposure rating classification found in Table III. 
Similar Exposure Groups (SEG) by Hazard 2011 / 2012

HAZARD: The following job titles are considered one SEG with potential exposure to Metal dusts and fumes.

\begin{tabular}{|c|c|c|c|c|c|c|}
\hline $\begin{array}{l}\text { Job Title \& No. } \\
\text { Employees }\end{array}$ & Task with potential exposure & Exposure Control & $\begin{array}{l}\text { Exposure } \\
\text { Rating }^{A}\end{array}$ & $\begin{array}{l}\text { Basis for } \\
\text { Rating }\end{array}$ & $\begin{array}{l}\text { Exposure } \\
\text { Judgment }\end{array}$ & $\begin{array}{l}\text { Action to } \\
\text { be taken }\end{array}$ \\
\hline $\begin{array}{c}\text { Light Duty } \\
\text { Mechanics (16) }\end{array}$ & $\begin{array}{l}\text { Welding, grinding, bead } \\
\text { blaster }\end{array}$ & $\begin{array}{l}\text { Exhaust ventilation / } \\
\text { gloves / respirator }\end{array}$ & 3 & $\begin{array}{l}\text { No sampling } \\
\text { data }\end{array}$ & Uncertain & $\begin{array}{c}\text { Air } \\
\text { monitoring }\end{array}$ \\
\hline $\begin{array}{c}\text { Heavy Duty } \\
\text { Mechanics (17) }\end{array}$ & $\begin{array}{l}\text { Welding, grinding, bead } \\
\text { blaster }\end{array}$ & $\begin{array}{l}\text { Exhaust ventilation / } \\
\text { gloves / respirator }\end{array}$ & 3 & $\begin{array}{l}\text { No sampling } \\
\text { data }\end{array}$ & Uncertain & $\begin{array}{c}\text { Air } \\
\text { monitoring }\end{array}$ \\
\hline $\begin{array}{l}\text { Auto Body / Paint } \\
\text { Mechanics (2) }\end{array}$ & $\begin{array}{l}\text { Sanding paint and body filler, } \\
\text { grinding }\end{array}$ & $\begin{array}{l}\text { Exhaust ventilation / } \\
\text { gloves / respirator }\end{array}$ & 3 & $\begin{array}{c}\text { No sampling } \\
\text { data }\end{array}$ & Uncertain & $\begin{array}{c}\text { Air } \\
\text { monitoring }\end{array}$ \\
\hline
\end{tabular}

Note: Mechanics work 4 days/week, 10 hours/day. Welding, grinding and sanding frequency less than once per week.

${ }^{\mathrm{A}}$ Exposure rating classification found in Table III. 


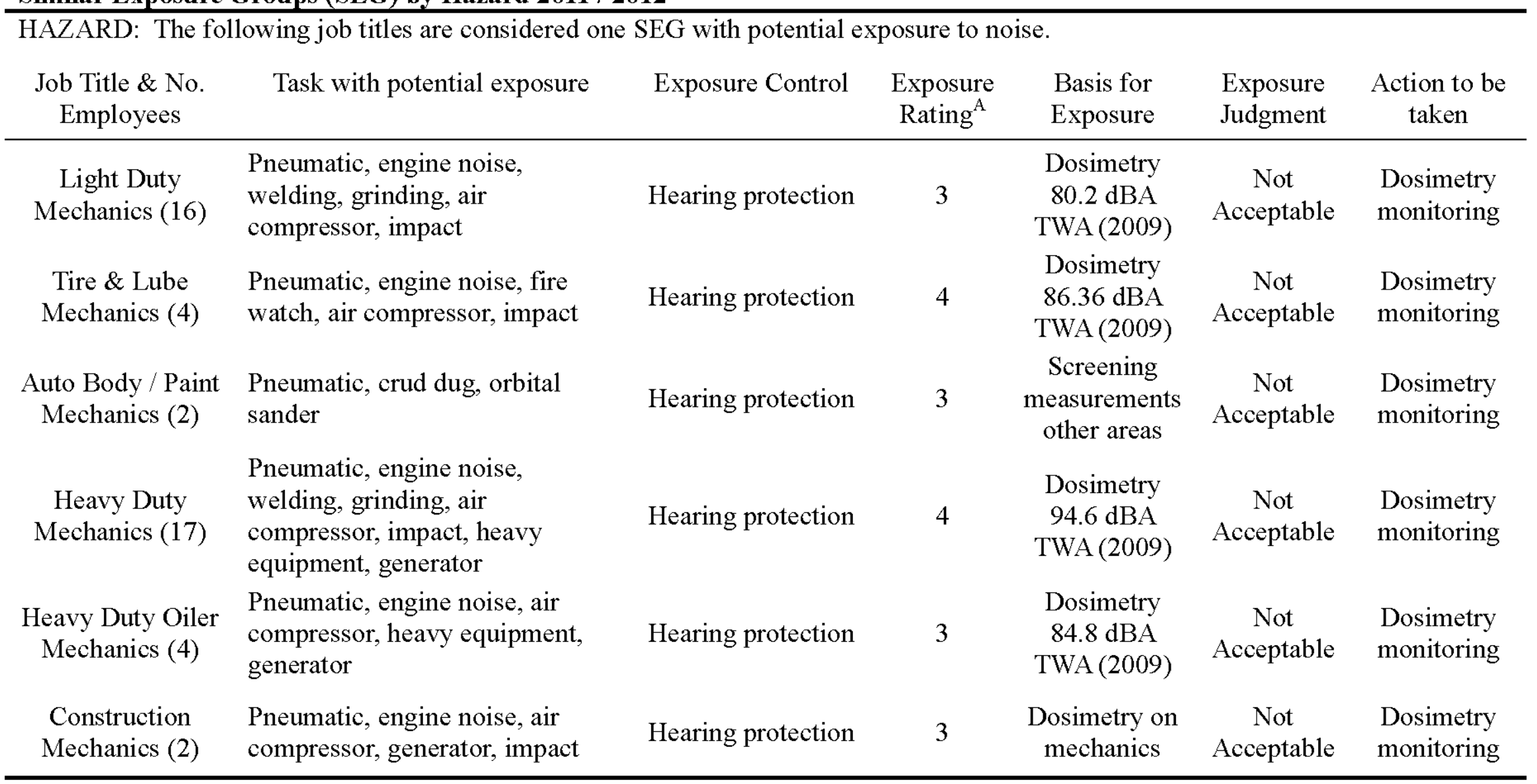

Note: Mechanics work 4 days/week, 10 hours/day. Noise exposure is intermittent each day with daily exposure.

${ }^{\mathrm{A}}$ Exposure rating classification found in Table III. 
VOC Sampling Data

APPENDIX B

Task: Forklift Hydraulic System Repair

\begin{tabular}{|c|c|c|c|c|c|c|c|c|c|c|c|c|}
\hline Sample ID & Date & Building & $\begin{array}{c}\text { Temp } \\
(\mathrm{F})\end{array}$ & $\begin{array}{l}\text { RH } \\
(\%) \\
\end{array}$ & Wind & On & Off & Min & $\begin{array}{l}\text { RDL } \\
(\mathrm{mg})\end{array}$ & $\begin{array}{c}\text { Sample } \\
\text { Conc. } \\
\text { (mg) }\end{array}$ & $\begin{array}{r}8 \mathrm{hr} \\
\text { TWA } \\
(\mathrm{ppm}) \\
\end{array}$ & Analyte \\
\hline 60248 & $6 / 18 / 12$ & & & & $10 \mathrm{mph}$ & & & & & & & \\
\hline BP7341 & Monday & $1 \mathrm{~A}$ & 69 & 32 & $280^{\circ}$ & $7: 50$ & $15: 50$ & 480 & 0.004 & $<0.004$ & $<0.08$ & Benzene \\
\hline & & & & & & & & & 0.004 & 0.14 & 3.37 & Acetone \\
\hline \multirow{4}{*}{\multicolumn{9}{|c|}{$\begin{array}{l}\text { Task Details: Employee worked on the hydraulic system during the morning and } \\
\text { early afternoon hours. The work was conducted inside the shop on the west end, } \\
\text { the rollup door was open during most of the work activity. No other work } \\
\text { occurred within this part of the shop during sampling. The employee indicated } \\
\text { that one large can of carburetor cleaner had been used for degreasing and cleaning } \\
\text { parts. Gumout Jetspray Carburetor and Choke Cleaner was used, with a } 2011 \\
\text { manufacturer date. The two main constituents are acetone and toluene. }\end{array}$}} & 0.004 & $<0.004$ & $<0.08$ & Ethyl Ether \\
\hline & & & & & & & & & 0.004 & $<0.004$ & $<0.06$ & n-Octane \\
\hline & & & & & & & & & 0.004 & 0.0098 & 0.17 & Toluene \\
\hline & & & & & & & & & 0.004 & $<0.004$ & $<0.07$ & Xylene \\
\hline
\end{tabular}

Task: Fuel Pump and Mass Air Flow Sensor Replacement

\begin{tabular}{|c|c|c|c|c|c|c|c|c|c|c|c|c|}
\hline Sample ID & Date & Building & $\begin{array}{l}\text { Temp } \\
\text { (F) }\end{array}$ & $\begin{array}{l}\mathrm{RH} \\
(\%) \\
\end{array}$ & Wind & On & Off & Min & $\begin{array}{l}\text { RDL } \\
(\mathrm{mg})\end{array}$ & $\begin{array}{c}\text { Sample } \\
\text { Conc. } \\
\text { (mg) }\end{array}$ & $\begin{array}{c}8 \mathrm{hr} \\
\text { TWA } \\
(\mathrm{ppm}) \\
\end{array}$ & Analyte \\
\hline 60248 & $6 / 18 / 12$ & & & & $10 \mathrm{mph}$ & & & & & & & \\
\hline BP7370 & Monday & 1 & 69 & 32 & $280^{\circ}$ & $7: 35$ & $15: 35$ & 480 & $\begin{array}{l}0.004 \\
0.004\end{array}$ & $\begin{array}{l}<0.004 \\
<0.004\end{array}$ & $\begin{array}{l}<0.08 \\
<0.1\end{array}$ & $\begin{array}{l}\text { Benzene } \\
\text { Acetone }\end{array}$ \\
\hline $\begin{array}{l}\text { Task Details: } \\
\text { airflow sensor. } \\
\text { from a truck. I } \\
\text { cleaner date } 20 \\
\text { of Ether (Johns } \\
\text { outside of the }\end{array}$ & $\begin{array}{l}\text { Employee } \\
\text { Employee } \\
\text { he employe } \\
11 \text { was use } \\
\text { sens Startin } \\
\text { hop as a so }\end{array}$ & $\begin{array}{l}\text { vorked insi } \\
\text { worked ou } \\
\text { e stated tha } \\
\text { 2-3 times } \\
\text { Fluid MS } \\
\text { vent and d }\end{array}$ & $\begin{array}{l}\text { de the } s \\
\text { doors i } \\
\text { t appro } \\
\text { during } \\
\text { OS 033 } \\
\text { grease }\end{array}$ & $\begin{array}{l}\text { lop to } \\
\text { after } \\
\text { imate } \\
\text { he day } \\
\text { (03) w }\end{array}$ & $\begin{array}{l}\text { replacing } \\
\text { loon to re } \\
\text { y } 1 / 2 \text { car } \\
\text {, and app } \\
\text { as used b }\end{array}$ & $\begin{array}{l}\text { a vehi } \\
\text { nove } t \\
\text { of carl } \\
\text { oxima } \\
\text { th insi }\end{array}$ & $\begin{array}{l}\text { le mass } \\
\text { le fuel } p \\
\text { uretor } \\
\text { ely } 1 / 4 \\
\text { le and }\end{array}$ & an & $\begin{array}{l}0.004 \\
0.004 \\
0.004 \\
0.004\end{array}$ & $\begin{array}{l}<0.004 \\
<0.004 \\
<0.004 \\
<0.004\end{array}$ & $\begin{array}{l}<0.08 \\
<0.06 \\
<0.07 \\
<0.07\end{array}$ & $\begin{array}{l}\text { Ethyl Ether } \\
\text { n-Octane } \\
\text { Toluene } \\
\text { Xylene }\end{array}$ \\
\hline
\end{tabular}


Task: Repair Boom and Auger on Lineman Truck

\begin{tabular}{|c|c|c|c|c|c|c|c|c|c|c|c|c|}
\hline Sample ID & Date & Building & $\begin{array}{c}\text { Temp } \\
\text { (F) }\end{array}$ & $\begin{array}{l}\text { RH } \\
(\%)\end{array}$ & Wind & On & Off & Min & $\begin{array}{l}\text { RDL } \\
(\mathrm{mg})\end{array}$ & $\begin{array}{c}\text { Sample } \\
\text { Conc. } \\
\text { (mg) }\end{array}$ & $\begin{array}{c}8 \mathrm{hr} \\
\text { TWA } \\
(\mathrm{ppm})\end{array}$ & Analyte \\
\hline 60251 & $6 / 20 / 12$ & & & & $10 \mathrm{mph}$ & & & & & & & \\
\hline BP7395 & Wed & $1 \mathrm{~A}$ & 73 & 28 & $100^{\circ}$ & $7: 46$ & $15: 44$ & 478 & $\begin{array}{l}0.004 \\
0.004\end{array}$ & $\begin{array}{l}<0.004 \\
<0.004\end{array}$ & $\begin{array}{l}<0.08 \\
<0.06\end{array}$ & $\begin{array}{l}\text { Benzene } \\
\text { n-Octane }\end{array}$ \\
\hline \multicolumn{9}{|c|}{$\begin{array}{l}\text { Task Details: Employee made some repairs to the pins and pin openings on the } \\
\text { boom for a lineman truck. The employee did not use any chemical products. The } \\
\text { truck was brought into the shop in the morning and due to the overall length, the } \\
\text { west rollup door remained open with the cab and engine compartment outdoors. } \\
\text { The truck engine was started several times throughout the day for manipulation } \\
\text { of the boom and auger. Other employees working in the shop used Teksol EP. } \\
\text { East wall rollup door remained closed throughout day. }\end{array}$} & $\begin{array}{l}0.004 \\
0.004\end{array}$ & $\begin{array}{l}<0.004 \\
<0.004\end{array}$ & $\begin{array}{l}<0.07 \\
<0.07\end{array}$ & $\begin{array}{l}\text { Toluene } \\
\text { Xylene }\end{array}$ \\
\hline
\end{tabular}

\section{Task: Install Toolboxes and Liftgate Latches}

\begin{tabular}{|c|c|c|c|c|c|c|c|c|c|c|c|c|}
\hline Sample ID & Date & Building & $\begin{array}{c}\text { Temp } \\
(\mathrm{F})\end{array}$ & $\begin{array}{l}\mathrm{RH} \\
(\%) \\
\end{array}$ & Wind & On & Off & Min & $\begin{array}{l}\text { RDL } \\
(\mathrm{mg}) \\
\end{array}$ & $\begin{array}{c}\text { Sample } \\
\text { Conc. } \\
\text { (mg) }\end{array}$ & $\begin{array}{r}8 \mathrm{hr} \\
\text { TWA } \\
(\mathrm{ppm}) \\
\end{array}$ & Analyte \\
\hline 60251 & $6 / 20 / 12$ & & & & $10 \mathrm{mph}$ & & & & & & & \\
\hline BP7420 & Wed & 1 & 73 & 28 & $100^{\circ}$ & $7: 55$ & $15: 53$ & 478 & 0.004 & $<0.004$ & $<0.08$ & Benzene \\
\hline & & & & & & & & & 0.004 & $<0.004$ & $<0.06$ & n-Octane \\
\hline \multirow{2}{*}{\multicolumn{9}{|c|}{$\begin{array}{l}\text { Task Details: Employee worked in the light equipment shop on vehicle safety } \\
\text { inspections, installing tailgate latches onto vehicles and also spent some time } \\
\text { outdoors installing toolboxes onto vehicles. Work tasks did not require the use of } \\
\text { chemicals. Three rollup doors along the south wall and the rollup door at the } \\
\text { lube bay were open throughout the work day. The wind fluctuated between } 5 \text { - } 10 \\
\text { mph out of the NNE - E blowing into the shop from lube bay on occasion. }\end{array}$}} & 0.004 & $<0.004$ & $<0.07$ & Toluene \\
\hline & & & & & & & & & 0.004 & $<0.004$ & $<0.07$ & Xylene \\
\hline
\end{tabular}


Task: Install Boom onto Lineman Truck

\begin{tabular}{|c|c|c|c|c|c|c|c|c|c|c|c|c|}
\hline Sample ID & Date & Building & $\begin{array}{c}\text { Temp } \\
\text { (F) }\end{array}$ & $\begin{array}{l}\text { RH } \\
(\%)\end{array}$ & Wind & On & Off & Min & $\begin{array}{l}\text { RDL } \\
(\mathrm{mg})\end{array}$ & $\begin{array}{c}\text { Sample } \\
\text { Conc. } \\
\text { (mg) }\end{array}$ & $\begin{array}{r}8 \mathrm{hr} \\
\text { TWA } \\
(\mathrm{ppm}) \\
\end{array}$ & Analyte \\
\hline 60267 & $6 / 27 / 12$ & & & & $5 \mathrm{mph}$ & & & & & & & \\
\hline BP7389 & Wed & 1 & 69 & 41 & SSW & $7: 54$ & $15: 51$ & 477 & 0.004 & $<0.004$ & $<0.08$ & Benzene \\
\hline \multirow{5}{*}{\multicolumn{9}{|c|}{$\begin{array}{l}\text { Task Details: Employee was working in } 2711 \mathrm{EA} \text {, with another employee to } \\
\text { install a boom onto a truck. This work required the use of degreasing agents } \\
\text { including Gumout Carb Cleaner ( } 2011 \text { ) and Johnsens Starting Fluid for } \\
\text { degreasing parts. The truck was parked near the east end of the shop and the } \\
\text { west rollup door was open. }\end{array}$}} & 0.004 & 0.061 & 1.47 & Acetone \\
\hline & & & & & & & & & 0.004 & 0.067 & 1.3 & Ethyl Ether \\
\hline & & & & & & & & & 0.004 & $<0.004$ & $<0.06$ & n-Octane \\
\hline & & & & & & & & & 0.004 & 0.0046 & 0.08 & Toluene \\
\hline & & & & & & & & & 0.004 & $<0.004$ & $<0.05$ & Trichloroethylene \\
\hline
\end{tabular}

Task: Replace Tires Change Engine Fluids

\begin{tabular}{|c|c|c|c|c|c|c|c|c|c|c|c|c|}
\hline Sample ID & Date & Building & $\begin{array}{c}\text { Temp } \\
\text { (F) }\end{array}$ & $\begin{array}{l}\mathrm{RH} \\
(\%) \\
\end{array}$ & Wind & On & Off & Min & $\begin{array}{l}\text { RDL } \\
(\mathrm{mg})\end{array}$ & $\begin{array}{c}\text { Sample } \\
\text { Conc. } \\
\text { (mg) }\end{array}$ & $\begin{array}{c}8 \mathrm{hr} \\
\text { TWA } \\
(\mathrm{ppm}) \\
\end{array}$ & Analyte \\
\hline 60267 & $6 / 27 / 12$ & & & & $5 \mathrm{mph}$ & & & & & & & \\
\hline GH8482 & Wed & 1 & 69 & 41 & SSW & $7: 42$ & $15: 04$ & 442 & 0.004 & $<0.004$ & $<0.08$ & Benzene \\
\hline & & & & & & & & & 0.004 & $<0.004$ & $<0.1$ & Acetone \\
\hline \multirow{4}{*}{\multicolumn{9}{|c|}{$\begin{array}{l}\text { Task Details: Employee worked in the light vehicle garage tire service bay } \\
\text { and the oil and lubrication service bay. Work involved changing four service } \\
\text { truck tires and changing engine oil and oil filters. Chemicals used include }< \\
1 / 4 \text { can of WD- } 40 \text {, Murphys Tire Lube (soap), engine oil and antifreeze. } \\
\text { Several vehicles were brought into the shop throughout the day but the } \\
\text { engines were not left running. }\end{array}$}} & 0.004 & $<0.004$ & $<0.08$ & Ethyl Ether \\
\hline & & & & & & & & & 0.004 & $<0.004$ & $<0.06$ & n-Octane \\
\hline & & & & & & & & & 0.004 & $<0.004$ & $<0.07$ & Toluene \\
\hline & & & & & & & & & 0.004 & $<0.004$ & $<0.05$ & Trichloroethylene \\
\hline
\end{tabular}


Task: Paint Wheels, Repair Vehicle Tires, Change Engine Fluids

\begin{tabular}{|c|c|c|c|c|c|c|c|c|c|c|c|c|}
\hline Sample ID & Date & Building & $\begin{array}{l}\text { Temp } \\
(\mathrm{F})\end{array}$ & $\begin{array}{l}\text { RH } \\
(\%) \\
\end{array}$ & Wind & On & Off & Min & $\begin{array}{l}\text { RDL } \\
(\mathrm{mg})\end{array}$ & $\begin{array}{c}\text { Sample } \\
\text { Conc. } \\
\text { (mg) }\end{array}$ & $\begin{array}{c}8 \mathrm{hr} \\
\text { TWA } \\
(\mathrm{ppm}) \\
\end{array}$ & Analyte \\
\hline 60268 & $6 / 28 / 12$ & & & & $7 \mathrm{mph}$ & & & & & & & \\
\hline GH8437 & Thurs & 1 & 80 & 29 & 340 & $8: 35$ & $16: 10$ & 455 & $\begin{array}{l}0.004 \\
0.004\end{array}$ & $\begin{array}{c}<0.004 \\
0.054\end{array}$ & $\begin{array}{c}<0.08 \\
1.3\end{array}$ & $\begin{array}{l}\text { Benzene } \\
\text { Acetone }\end{array}$ \\
\hline \multicolumn{9}{|c|}{$\begin{array}{l}\text { Task Details: Employee worked in the tire service bay and oil lubrication } \\
\text { bay. Tasks included using one can Krylon black spray paint (msds \#069681) } \\
\text { to paint four wheels, repairing and patching tires using patching cement } \\
\text { (Heptane), replacing tires using WD-40 and Murphys lubrication soap, in } \\
\text { addition to changing engine oil and oil filters on vehicles. }\end{array}$} & $\begin{array}{l}0.004 \\
0.004 \\
0.008 \\
0.004\end{array}$ & $\begin{array}{l}<0.004 \\
0.0098 \\
<0.008 \\
<0.004\end{array}$ & $\begin{array}{l}<0.06 \\
0.17 \\
<0.15 \\
<0.05\end{array}$ & $\begin{array}{l}\text { n-Octane } \\
\text { Toluene } \\
\text { Xylene } \\
\text { Trichloroethylene }\end{array}$ \\
\hline
\end{tabular}

\section{Task: Repair Electrical Components on Flatbed}

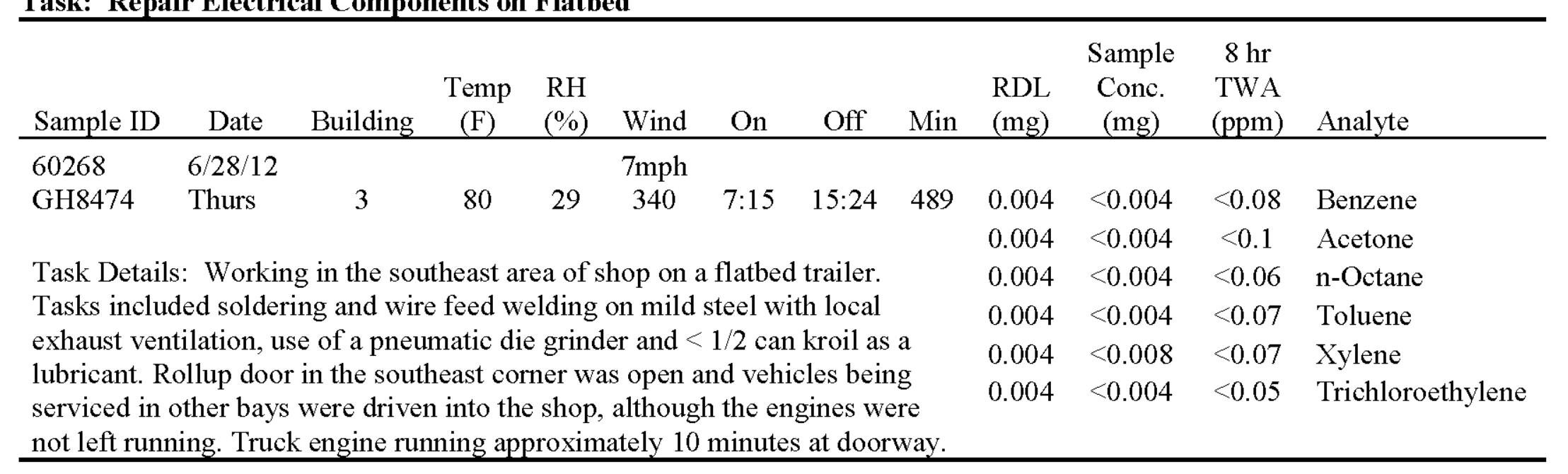


Task: Replace Tires, Change Engine Fluids

\begin{tabular}{|c|c|c|c|c|c|c|c|c|c|c|c|c|}
\hline Sample ID & Date & Building & $\begin{array}{c}\text { Temp } \\
(\mathrm{F})\end{array}$ & $\begin{array}{l}\text { RH } \\
(\%) \\
\end{array}$ & Wind & On & Off & Min & $\begin{array}{l}\text { RDL } \\
(\mathrm{mg}) \\
\end{array}$ & $\begin{array}{l}\text { Sample } \\
\text { Conc. } \\
(\mathrm{mg})\end{array}$ & $\begin{array}{r}8 \mathrm{hr} \\
\text { TWA } \\
(\mathrm{ppm}) \\
\end{array}$ & Analyte \\
\hline 60268 & $6 / 28 / 12$ & & & & $7 \mathrm{mph}$ & $7: 2$ & 15: & & & & & \\
\hline GH8478 & Thurs & 3 & 80 & 29 & 340 & 1 & 45 & 504 & 0.004 & $<0.004$ & $<0.08$ & Benzene \\
\hline & & & & & & & & & 0.004 & $<0.004$ & $<0.1$ & Acetone \\
\hline \multirow{4}{*}{\multicolumn{9}{|c|}{$\begin{array}{l}\text { Task Details: EWork tasks involved repairing and replacing tires both inside } \\
\text { the shop and on service calls, changing engine oil and filters in vehicles and } \\
\text { checking and filling other vehicle fluids. No chemicals, other than engine oil } \\
\text { was used. }\end{array}$}} & 0.004 & $<0.004$ & $<0.06$ & n-Octane \\
\hline & & & & & & & & & 0.004 & $<0.004$ & $<0.07$ & Toluene \\
\hline & & & & & & & & & 0.008 & $<0.008$ & $<0.07$ & Xylene \\
\hline & & & & & & & & & 0.004 & $<0.004$ & $<0.05$ & Trichloroethylene \\
\hline
\end{tabular}

Task: Clean Metal Surfaces with Solvent (Personal Sample

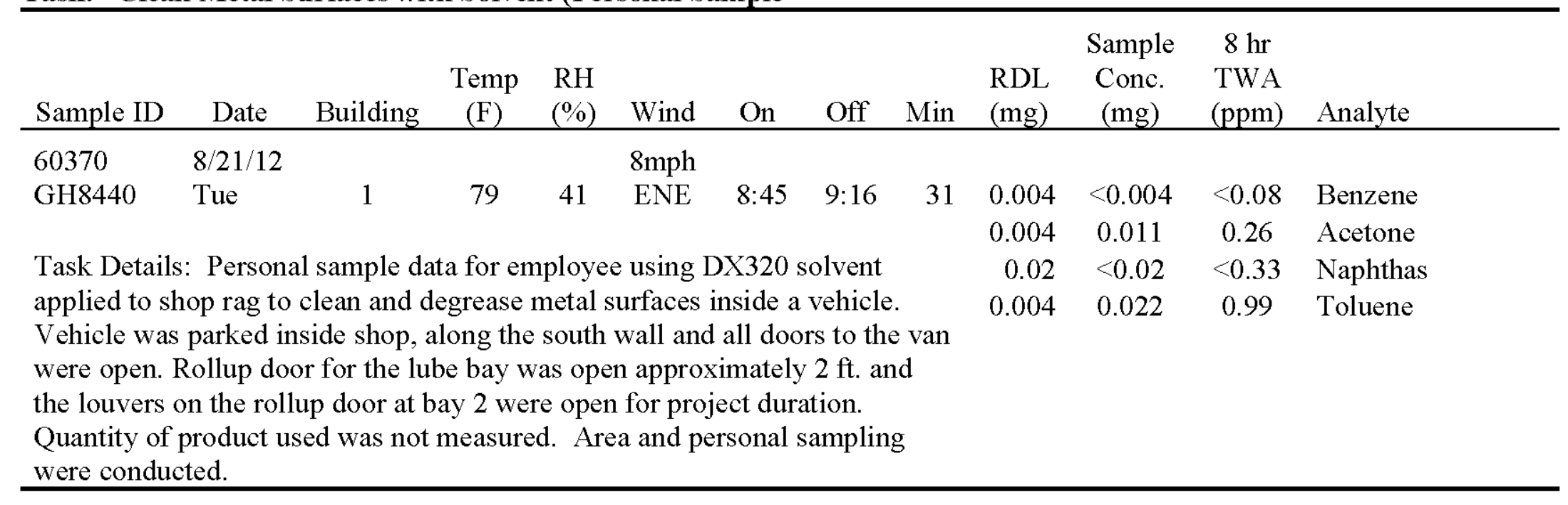


Task: Clean Metal Surfaces with Solvent (Area Sample)

\begin{tabular}{|c|c|c|c|c|c|c|c|c|c|c|c|c|}
\hline Sample ID & Date & Building & $\begin{array}{c}\text { Temp } \\
(\mathrm{F})\end{array}$ & $\begin{array}{l}\text { RH } \\
(\%) \\
\end{array}$ & Wind & On & Off & Min & $\begin{array}{l}\text { RDL } \\
(\mathrm{mg})\end{array}$ & $\begin{array}{c}\text { Sample } \\
\text { Conc. } \\
\text { (mg) }\end{array}$ & $\begin{array}{c}\text { Sample } \\
\text { Conc. } \\
\text { (ppm) }\end{array}$ & Analyte \\
\hline 60370 & $8 / 21 / 12$ & & & & $8 \mathrm{mph}$ & & & & & & & \\
\hline GH8466 & Tue & 1 & 79 & 41 & ENE & $8: 44$ & $9: 11$ & 27 & 0.004 & $<0.004$ & $<1.34$ & Benzene \\
\hline & & & & & & & & & 0.004 & 0.034 & 14.53 & Acetone \\
\hline \multirow{2}{*}{\multicolumn{9}{|c|}{$\begin{array}{l}\text { Task Details: Area sample data for metal surface cleaning using solvent } \\
\text { applied to shop rag. }\end{array}$}} & 0.02 & $<0.02$ & $<5.93$ & Naphthas \\
\hline & & & & & & & & & 0.004 & 0.063 & 19.72 & Toluene \\
\hline
\end{tabular}

\section{Task: Using Aerosol Spray Paint (Personal Sample 1)}

\begin{tabular}{|c|c|c|c|c|c|c|c|c|c|c|c|c|}
\hline $\begin{array}{c}\text { Sample } \\
\text { ID }\end{array}$ & Date & Building & $\begin{array}{l}\text { Temp } \\
\text { (F) }\end{array}$ & $\begin{array}{l}\mathrm{RH} \\
(\%)\end{array}$ & Wind & On & Off & Min & $\begin{array}{l}\text { RDL } \\
(\mathrm{mg})\end{array}$ & $\begin{array}{c}\text { Sample } \\
\text { Conc. } \\
(\mathrm{mg})\end{array}$ & $\begin{array}{c}8 \mathrm{hr} \\
\text { TWA } \\
(\mathrm{ppm}) \\
\end{array}$ & Analyte \\
\hline 60374 & $8 / 22 / 12$ & & & & $13 \mathrm{mph}$ & & & & & & & \\
\hline GH8449 & Wed & 2 & 76 & 30 & 290 & $9: 52$ & $11: 22$ & 90 & 0.004 & $<0.004$ & $<0.08$ & Benzene \\
\hline \multirow{3}{*}{\multicolumn{9}{|c|}{$\begin{array}{l}\text { Task Details: Employee cleaning and degreasing trailer surfaces and applying } \\
\text { two cans of specially formulated spray paint. Two employees were } \\
\text { performing this task. Each employee wore a personal sampling badge. }\end{array}$}} & 0.004 & $<0.004$ & $<0.09$ & MEK \\
\hline & & & & & & & & & 0.004 & 0.012 & 0.21 & Toluene \\
\hline & & & & & & & & & 0.008 & 0.0093 & 0.17 & Xylene \\
\hline
\end{tabular}


Task: Using Aerosol Spray Paint (Personal Sample 2)

\begin{tabular}{|c|c|c|c|c|c|c|c|c|c|c|c|c|}
\hline Sample ID & Date & Building & $\begin{array}{c}\text { Temp } \\
\text { (F) }\end{array}$ & $\begin{array}{l}\mathrm{RH} \\
(\%)\end{array}$ & Wind & On & Off & Min & $\begin{array}{l}\text { RDL } \\
(\mathrm{mg})\end{array}$ & $\begin{array}{l}\text { Sample } \\
\text { Conc. } \\
\text { (mg) }\end{array}$ & $\begin{array}{l}8 \mathrm{hr} \\
\text { TWA } \\
(\mathrm{ppm})\end{array}$ & Analyte \\
\hline 60374 & $8 / 22 / 12$ & & & & $13 \mathrm{mph}$ & & & & & & & \\
\hline GH8501 & Wed & 2 & 76 & 30 & 290 & $9: 54$ & $11: 20$ & 86 & 0.004 & $<0.004$ & $<0.08$ & Benzene \\
\hline \multirow{3}{*}{\multicolumn{9}{|c|}{$\begin{array}{l}\text { Task Details: Employee cleaning and degreasing trailer surfaces and applying } \\
\text { two cans of specially formulated spray paint. Two employees were performing } \\
\text { this task. Each emnlovee wore a nersonal samnling badoe }\end{array}$}} & 0.004 & $<0.004$ & $<0.09$ & MEK \\
\hline & & & & & & & & & 0.004 & 0.02 & 0.35 & Toluene \\
\hline & & & & & & & & & 0.008 & 0.01 & 0.18 & Xylene \\
\hline
\end{tabular}




\section{APPENDIX C}

\section{Sample Collection Data (Metals)}

\section{Task: Using Hand-held Grinder to Remove Paint}

\begin{tabular}{|c|c|c|c|c|c|c|c|c|c|c|}
\hline $\begin{array}{c}\text { Sample } \\
\text { ID }^{\mathrm{A}}\end{array}$ & Date & Building & Controls & $\begin{array}{l}\text { Exp. } \\
\text { Min }\end{array}$ & $\begin{array}{l}\text { flow } \\
\text { start }\end{array}$ & $\begin{array}{l}\text { flow } \\
\text { end }\end{array}$ & $\begin{array}{l}\text { flow } \\
\text { ave }\end{array}$ & volume & Pump & Calibrator \\
\hline 60206-P1 & $5 / 23 / 12$ & 2 & $\begin{array}{l}\text { Respirator / } \\
\text { LEV }^{\mathrm{B}}\end{array}$ & 86 & 2.508 & 2.479 & 2.49 & 214.44 & $\begin{array}{l}224- \\
\text { PCXR7 } \\
\text { SKC } \\
224-\end{array}$ & $\begin{array}{l}\text { BIOS Dry } \\
\text { Cal } 5 \mathrm{~K}\end{array}$ \\
\hline 60206-P2 & & & & 63 & 2.508 & 2.479 & 2.49 & 157.09 & $\begin{array}{l}\text { PCXR7 } \\
\text { SKC } \\
224-\end{array}$ & $\begin{array}{l}\text { BIOS Dry } \\
\text { Cal 5K }\end{array}$ \\
\hline 60206-A1 & & & & 224 & 2.797 & 2.758 & 2.78 & 622.16 & $\begin{array}{l}\text { PCXR8 } \\
\text { SKC } \\
224-\end{array}$ & $\begin{array}{l}\text { BIOS Dry } \\
\text { Cal 5K }\end{array}$ \\
\hline 60206-A2 & & & & 226 & 2.672 & 2.683 & 2.68 & 605.12 & $\begin{array}{l}\text { PCXR4 } \\
\text { SKC }\end{array}$ & $\begin{array}{l}\text { BIOS Dry } \\
\text { Cal 5K }\end{array}$ \\
\hline
\end{tabular}


Task: Using Orbital Sander for Paint Removal

\begin{tabular}{|c|c|c|c|c|c|c|c|c|c|c|}
\hline $\begin{array}{c}\text { Sample } \\
\text { ID }^{A}\end{array}$ & Date & Building & Controls & $\begin{array}{l}\text { Exp. } \\
\text { Min }\end{array}$ & $\begin{array}{l}\text { flow } \\
\text { start }\end{array}$ & $\begin{array}{l}\text { flow } \\
\text { end }\end{array}$ & $\begin{array}{c}\text { flow } \\
\text { ave }\end{array}$ & volume & Pump & Calibrator \\
\hline 60236-P1 & $6 / 12 / 12$ & 4 & $\begin{array}{l}\text { Vacuum, } \\
\text { respirator }\end{array}$ & 258 & 2.512 & 2.524 & 2.52 & 649.64 & $\begin{array}{l}224- \\
\text { PCXR8 } \\
\text { SKC } \\
224-\end{array}$ & $\begin{array}{l}\text { BIOS Dry } \\
\text { Cal } 5 \mathrm{~K}\end{array}$ \\
\hline 60236-P2 & $6 / 12 / 12$ & 4 & $\begin{array}{l}\text { Vacuum, } \\
\text { respirator }\end{array}$ & 259 & 2.672 & 2.742 & 2.71 & 701.11 & $\begin{array}{l}\text { PCXR4 } \\
\text { SKC } \\
224-\end{array}$ & $\begin{array}{l}\text { BIOS Dry } \\
\text { Cal } 5 \mathrm{~K}\end{array}$ \\
\hline 60236-A1 & $6 / 12 / 12$ & 4 & None & 259 & 2.827 & 2.794 & 2.81 & 727.92 & $\begin{array}{l}\text { PCXR8 } \\
\text { SKC }\end{array}$ & $\begin{array}{l}\text { BIOS Dry } \\
\text { Cal 5K }\end{array}$ \\
\hline
\end{tabular}

\section{Task: Air Arc Cutting and Grinding on Painted Surface}

\begin{tabular}{|c|c|c|c|c|c|c|c|c|c|c|}
\hline $\begin{array}{c}\text { Sample } \\
\text { ID }^{A}\end{array}$ & Date & Building & Controls & $\begin{array}{l}\text { Exp. } \\
\text { Min } \\
\end{array}$ & $\begin{array}{l}\text { flow } \\
\text { start }\end{array}$ & $\begin{array}{l}\text { flow } \\
\text { end }\end{array}$ & $\begin{array}{c}\text { flow } \\
\text { ave }\end{array}$ & volume & Pump & Calibrator \\
\hline 60345-P1 & $8 / 7 / 12$ & 2 & $\begin{array}{l}\text { floor fan, } \\
\text { LEV }\end{array}$ & 75 & 2.865 & 2.801 & 2.83 & 212.48 & $\begin{array}{l}480 \text { Elf } \\
\text { MSA } \\
224-\end{array}$ & $\begin{array}{l}\text { BIOS Dry } \\
\text { Cal 5K }\end{array}$ \\
\hline 60345-A1 & $8 / 7 / 12$ & 2 & None & 75 & 2.772 & 2.684 & 2.73 & 204.60 & $\begin{array}{l}\text { PCXR4 } \\
\text { SKC }\end{array}$ & $\begin{array}{l}\text { BIOS Dry } \\
\text { Cal 5K }\end{array}$ \\
\hline
\end{tabular}

\footnotetext{
Sample ID ending in P1 represents breathing zone sample; sample ID ending in A1 represents area sample.
} 
Task: Using Torch to Remove Welds from Painted Metal Canopy

\begin{tabular}{|c|c|c|c|c|c|c|c|c|c|c|}
\hline $\begin{array}{c}\text { Sample } \\
\text { ID }^{\mathrm{A}}\end{array}$ & Date & Building & Controls & $\begin{array}{l}\text { Exp. } \\
\text { Min }\end{array}$ & $\begin{array}{l}\text { flow } \\
\text { start }\end{array}$ & $\begin{array}{l}\text { flow } \\
\text { end }\end{array}$ & $\begin{array}{l}\text { flow } \\
\text { ave }\end{array}$ & volume & Pump & Calibrator \\
\hline $\begin{array}{l}\text { 60201- } \\
\text { P1 }\end{array}$ & $5 / 22 / 12$ & 2 & Respirator & 60 & 2.506 & 2.493 & 2.5 & 149.97 & $\begin{array}{l}224- \\
\text { PCXR7 } \\
\text { SKC } \\
224-\end{array}$ & $\begin{array}{l}\text { BIOS Dry } \\
\text { Cal } 5 \mathrm{~K}\end{array}$ \\
\hline $\begin{array}{l}\text { 60201- } \\
\text { P2 }\end{array}$ & $5 / 22 / 12$ & 2 & & 62 & 2.507 & 2.507 & 2.51 & 155.43 & $\begin{array}{l}\text { PCXR8 } \\
\text { SKC }\end{array}$ & $\begin{array}{l}\text { BIOS Dry } \\
\text { Cal 5K }\end{array}$ \\
\hline
\end{tabular}

\section{Task: Orbital Sander for Paint Removal}

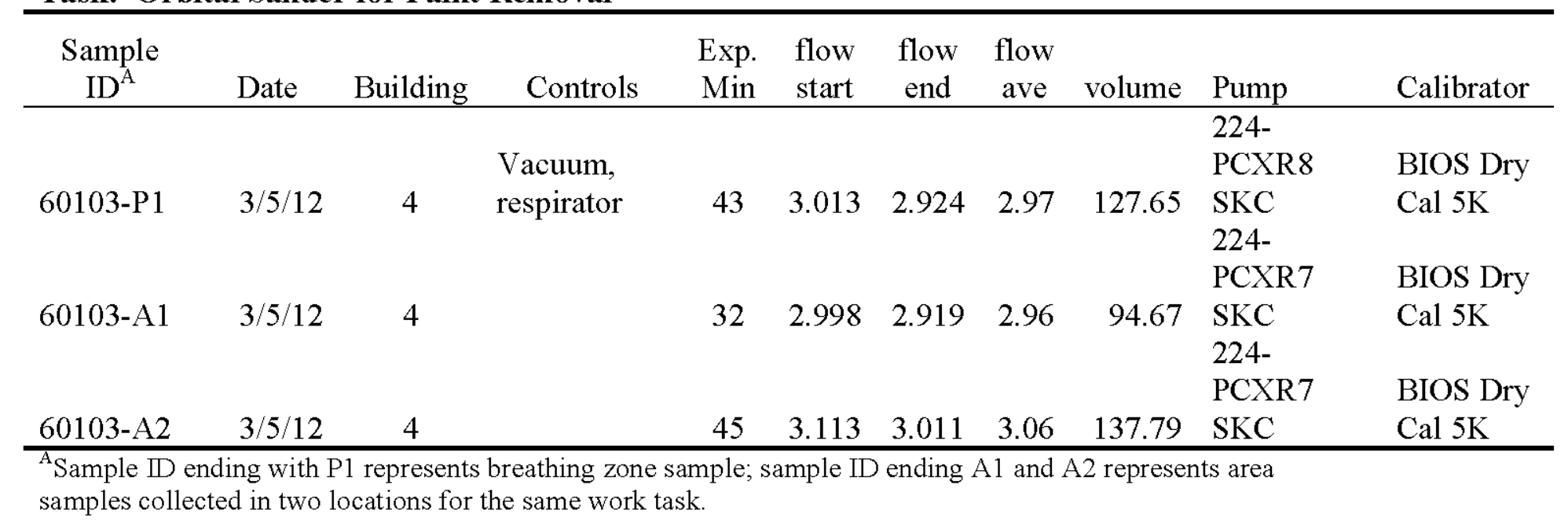


Task: Servicing Bead Blaster Unit

\begin{tabular}{|c|c|c|c|c|c|c|c|c|c|c|}
\hline $\begin{array}{c}\text { Sample } \\
\text { ID }^{\mathrm{A}}\end{array}$ & Date & Building & Controls & $\begin{array}{l}\text { Exp. } \\
\text { Min }\end{array}$ & $\begin{array}{l}\text { flow } \\
\text { start }\end{array}$ & $\begin{array}{c}\text { flow } \\
\text { end }\end{array}$ & $\begin{array}{c}\text { flow } \\
\text { ave }\end{array}$ & volume & Pump & Calibrator \\
\hline $\begin{array}{l}\text { 60171- } \\
\text { P1 }\end{array}$ & $4 / 25 / 12$ & 1 & Respirator & 61 & 2.018 & 1.985 & 2 & 122.09 & $\begin{array}{l}224- \\
\text { PCXR8 } \\
\text { SKC } \\
224-\end{array}$ & $\begin{array}{l}\text { BIOS Dry } \\
\text { Cal 5K }\end{array}$ \\
\hline $\begin{array}{l}\text { 60171- } \\
\text { A1 }\end{array}$ & $4 / 25 / 12$ & 1 & & 61 & 2.004 & 1.979 & 1.99 & 121.48 & $\begin{array}{l}\text { PCXR8 } \\
\text { SKC }\end{array}$ & $\begin{array}{l}\text { BIOS Dry } \\
\text { Cal 5K }\end{array}$ \\
\hline
\end{tabular}




\section{APPENDIX D}

Noise Monitoring Data (Heavy Equipment Mechanics)

\begin{tabular}{|c|c|c|c|c|c|c|c|c|c|c|c|c|c|}
\hline ID & Date & Bldg & Tasks & Equipment & Side & On & Off & $\begin{array}{l}\text { Time } \\
\min \end{array}$ & Dose & Lavg & TWA & Lasmx & Day \\
\hline $22 \mathrm{~J}$ & $2 / 23$ & 1 & Welding/grinding & $\begin{array}{l}\text { hand held grinding } \\
\text { wheel, needle scaler }\end{array}$ & left & $7: 23$ & $15: 08$ & 465 & 389.5 & 91 & 90.9 & 111.2 & Thur \\
\hline $24 \mathrm{~J}$ & $2 / 29$ & 1 & $\begin{array}{l}\text { diesel forklift } \\
\text { repair }\end{array}$ & $\begin{array}{l}\text { 1/2" impact wrench, } \\
\text { hand tools, } \\
\text { compressor }\end{array}$ & left & $7: 54$ & $15: 30$ & 456 & 41.3 & 81.3 & 81.1 & 106.7 & Wed \\
\hline $34 \mathrm{~J}$ & $6 / 20$ & 1 & $\begin{array}{l}\text { Remove auger, } \\
\text { repair pin and pin } \\
\text { hole on lineman } \\
\text { truck boom }\end{array}$ & $\begin{array}{l}\text { pneumatic bluepoint } \\
\text { rotary }\end{array}$ & right & $7: 46$ & $15: 41$ & 475 & 20.9 & 78.2 & 78.2 & 103.1 & Wed \\
\hline $27 \mathrm{~J}$ & $7 / 11$ & 1 & $\begin{array}{l}\text { Repair } \\
\text { emergency } \\
\text { generator }\end{array}$ & Hand tools & left & $7: 23$ & $15: 23$ & 480 & 54.6 & 82.3 & 82.3 & 104.4 & Wed \\
\hline
\end{tabular}


Noise Monitoring Data (Light Equipment Mechanics)

\begin{tabular}{|c|c|c|c|c|c|c|c|c|c|c|c|c|}
\hline ID & Date & Bldg & Tasks & Equipment & Side & On & Off & $\begin{array}{l}\text { Time } \\
(\min )\end{array}$ & Dose & TWA & Lasmx & Day \\
\hline $40 \mathrm{~A}$ & $2 / 23$ & 1 & $\begin{array}{l}\text { Mounting tires, } \\
\text { oil change }\end{array}$ & 3/4" Impact wrench & left & $7: 14$ & $15: 26$ & 492 & 131 & 86.1 & 108.9 & Thur \\
\hline $26 \mathrm{~A}$ & $2 / 23$ & 1 & Repair a lift gate & $\begin{array}{l}\text { Hand held grinder } \\
\text { (blue point), battery } \\
\text { operated impact driver }\end{array}$ & left & $8: 16$ & $15: 20$ & 424 & 84.5 & 84.2 & 109.3 & Thur \\
\hline $32 \mathrm{~A}$ & $2 / 23$ & 1 & $\begin{array}{l}\text { Oil change } \\
\text { service }\end{array}$ & Hand tools & left & $7: 16$ & $15: 24$ & 488 & 21.6 & 78.3 & 106.1 & Thur \\
\hline $20 \mathrm{~A}$ & $2 / 22$ & 1 & $\begin{array}{l}\text { Part fabrication } \\
\text { weld/grind }\end{array}$ & $\begin{array}{c}\text { Hand held grinding } \\
\text { wheel }\end{array}$ & left & $7: 23$ & $15: 21$ & 418 & 142 & 86.5 & 109.3 & Wed \\
\hline $22 \mathrm{~A}$ & $2 / 22$ & 1 & Fire watch & $\begin{array}{l}15 \mathrm{ft} \text { from grinding } \\
\text { wheel }\end{array}$ & left & $8: 16$ & $15: 21$ & 425 & 30.2 & 79.8 & 104.6 & Wed \\
\hline $25 \mathrm{~A}$ & $2 / 28$ & 1 & $\begin{array}{l}\text { Replace EGR } \\
\text { cooler }\end{array}$ & $\begin{array}{c}3 / 8 " \text { Bluepoint } \\
\text { wrench, die grinder }\end{array}$ & right & $7: 32$ & $15: 18$ & 466 & 35.7 & 80.5 & 108.2 & Tue \\
\hline $19 \mathrm{~A}$ & $2 / 28$ & 1 & $\begin{array}{l}\text { Replacing } \\
\text { shocks }\end{array}$ & $\begin{array}{l}1 / 2 " \text { Impact wrench, } \\
\text { cordless impact drill }\end{array}$ & left & $7: 36$ & $15: 23$ & 467 & 44.1 & 81.4 & 112.6 & Tue \\
\hline $21 \mathrm{~A}$ & $2 / 28$ & 2 & $\begin{array}{l}\text { Assist with } \\
\text { equipment } \\
\text { installation }\end{array}$ & $\begin{array}{c}\text { Hand held grinding } \\
\text { wheel }\end{array}$ & left & $7: 52$ & $15: 12$ & 440 & 35.2 & 80.4 & 112.6 & Tue \\
\hline $6 \mathrm{~J}$ & $2 / 28$ & field & $\begin{array}{l}\text { Oil change, tire } \\
\text { change, metal } \\
\text { straightening }\end{array}$ & $\begin{array}{c}\text { Impact wrench, } \\
\text { cheetah bead seater, } \\
\text { hammer }\end{array}$ & left & $8: 02$ & $15: 42$ & 460 & 182 & 87.6 & 119.2 & Tue \\
\hline
\end{tabular}




\begin{tabular}{|c|c|c|c|c|c|c|c|c|c|c|c|c|}
\hline ID & Date & Bldg & Tasks & Equipment & Side & On & Off & $\begin{array}{l}\text { Time } \\
(\min )\end{array}$ & Dose & TWA & Lasmx & Day \\
\hline $30 \mathrm{~A}$ & $3 / 1$ & 1 & $\begin{array}{l}\text { Draining shocks, } \\
\text { replacing vehicle } \\
\text { fluids, wiper blades }\end{array}$ & Air drill & left & $7: 51$ & $15: 28$ & 457 & 76.6 & 83.8 & 107.1 & Thur \\
\hline $3 \mathrm{~J}$ & $3 / 5$ & 4 & $\begin{array}{l}\text { Install truck bed, } \\
\text { door, decals }\end{array}$ & $\begin{array}{l}1 / 4 " \text { Wrench ratchet, } \\
1 / 2 \text { " impact wrench, } \\
\text { rotary tool to remove } \\
\text { old decal }\end{array}$ & left & $8: 10$ & $15: 30$ & 440 & 80 & 84 & 114.3 & Mon \\
\hline $4 \mathrm{~J}$ & $3 / 5$ & 4 & $\begin{array}{l}\text { Mechanical paint } \\
\text { removal, assist with } \\
\text { install of truck bed }\end{array}$ & $\begin{array}{l}\text { Orbital sander, } 1 / 2 " \\
\text { impact wrench }\end{array}$ & left & $8: 17$ & $15: 31$ & 434 & 44.9 & 81.5 & 109.7 & Mon \\
\hline $18 \mathrm{~A}$ & $5 / 23$ & 2 & $\begin{array}{l}\text { Fire watch, parts } \\
\text { fabrication }\end{array}$ & $\begin{array}{l}\text { Hand held grinding } \\
\text { wheel, belt sander, drill } \\
\text { press, die grinder }\end{array}$ & right & $7: 58$ & $15: 43$ & 465 & 91.3 & 84.6 & 110.8 & Wed \\
\hline $20 \mathrm{~A}$ & $6 / 13$ & 1 & Welding/grinding & $\begin{array}{c}\text { Hand-held grinding } \\
\text { wheel }\end{array}$ & right & $7: 47$ & $15: 25$ & 458 & 23.3 & 78.6 & 112 & Wed \\
\hline $30 \mathrm{~A}$ & $6 / 13$ & 1 & $\begin{array}{l}\text { Replacing brake } \\
\text { cylinder }\end{array}$ & $\begin{array}{l}\text { Hand tools/hammer on } \\
\text { metal }\end{array}$ & left & $7: 49$ & $15: 30$ & 461 & 25.9 & 79.1 & 108.5 & Wed \\
\hline $25 \mathrm{~A}$ & $6 / 14$ & 1 & $\begin{array}{l}\text { Replace cable chain } \\
\text { on rolloff can truck }\end{array}$ & $\begin{array}{c}\text { Chop saw, } 1 / 2 \text { " impact } \\
\text { wrench, battery operated } \\
\text { torque wrench }\end{array}$ & left & $7: 34$ & $15: 40$ & 486 & 52.4 & 82.1 & 106.5 & Thur \\
\hline $7 \mathrm{~J}$ & $6 / 14$ & field & $\begin{array}{l}\text { Change \& air up } \\
\text { tire, drive fuel truck }\end{array}$ & $\begin{array}{c}\text { Impact wrench, cheetah } \\
\text { bead seater, air } \\
\text { compressor }\end{array}$ & right & $7: 40$ & $15: 13$ & 453 & 22.7 & 78.5 & 107.7 & Thur \\
\hline
\end{tabular}


Noise Monitoring Data (Light Equipment Mechanics) Continued

\begin{tabular}{cccccccccccccccc}
\hline ID & Date & Bldg & Tasks & Equipment & Side & On & Off & $\begin{array}{c}\text { Time } \\
(\min )\end{array}$ & Dose & TWA Lasmx & Day \\
\hline $36 \mathrm{~A}$ & $6 / 28$ & 3 & $\begin{array}{c}\text { Repair hydraulic } \\
\text { system, weld/grind }\end{array}$ & Die grinder & right & $7: 16$ & $15: 25$ & 488 & 18.6 & 77.7 & 110.5 & Thur \\
$40 \mathrm{~A}$ & $6 / 28$ & 3 & $\begin{array}{c}\text { Tire \& lube shop } \\
\text { and field }\end{array}$ & Impact wrench & right & $7: 19$ & $15: 47$ & 508 & 20.7 & 78.1 & 104.8 & Thur \\
$27 \mathrm{~A}$ & $8 / 7$ & 2 & Welding/grinding & $\begin{array}{c}\text { Air arc welding/hand- } \\
\text { held grinding wheel }\end{array}$ & left & $7: 17$ & $15: 29$ & 492 & 273 & 89.3 & 108.8 & Tue \\
\hline
\end{tabular}

